\title{
INTRODUÇÃO
}

Esta pesquisa aborda a Educação Física Escolar em sua produção acadêmica etnográfica, nas apropriações feitas ao referencial teórico-metodológico etnográfico, sobre os procedimentos de coletas de dados com observação participante; o uso de entrevistas semiestruturadas e análises documentais; a interpretação dos dados realizada e os resultados apresentados. Aspectos curriculares, emergidos do material empírico de dissertações e teses, foram destacados e analisados teoricamente a partir dos currículos Crítico-superador e Cultural em Educação Física Escolar.

Coadunando com a ideia de que a Educação Física vem tentando, ao longo dos anos, conquistar um espaço diferenciado no que se refere a seu objeto de estudo, campos e formas de atuação (KUNZ, 2004), diante do muito que se tem discutido e produzido na área nesse sentido, para as finalidades desta pesquisa, foram apresentadas as seguintes questões: como são realizadas as etnografias escolares em Educação Física e quais relações teóricas, documentais, oficiais, curriculares podem ser estabelecidas no conjunto das pesquisas analisadas?

Bracht (2002), ao apresentar um paralelo entre o debate ocorrido a partir da década de 1980 - marcadamente de orientação marxista - no cenário do pensamento pedagógico brasileiro e sua especificidade dentro das discussões na Educação Física, afirma que mesmo tendo sido apresentadas propostas pedagógicas progressistas pela área, “[...] a adesão 'teórica' às propostas pedagógicas críticas parece ser maior do que sua efetiva prática" (p.10).

Nesse contexto idiossincrático, seria possível formar professores capazes de promover o debate sobre os processos de opressão, ideologizações e desigualdades sociais contidas nas práticas corporais, porém sem apresentar, com clareza e método, o como intervir e produzir possibilidades reais de transformação em suas práticas pedagógicas escolares (BRACHT; CAPARROZ, 2007).

Ainda que com os esforços teóricos e pesquisas que a área vem desenvolvendo na busca por novas ressignificações de suas práticas pedagógicas, há que se considerar que o panorama curricular, na maioria das redes, apresenta configurações e aplicações conflitantes e limitadas, assim como, de acordo com Neira (2011a) as práticas desenvolvidas nas aulas de Educação Física levadas a efeito no nosso país, [...] denunciam o padecimento da ousadia diante da colonização ainda presente nos currículos da área" (p. 39), apontando ainda o fato de que nas pouquíssimas vezes em que os 
“esportes brancos”, ‘cristãos`e `euroamericanos` são questionados são substituídos por exercícios (de caráter psicomotor) e/ou brincadeiras descontextualizadas da cultura local e que, em última instância, contribuem para a continuidade da mesma representação do mundo `cristão’, 'branco`e 'euroamericano.

Aos professores não seria permitido compreender, a partir dos currículos que thes são fornecidos no percurso de sua formação, a complexa rede de inter-relações que dizem respeito à multiplicidade de fatores que incidem sobre a cultura corporal dos sujeitos em sociedade e suas possibilidades em relação às diferentes abordagens pedagógicas que os estudos e pesquisas da área sugerem.

Pode-se notar, na própria formação dos professores de Educação Física, que as práticas escolares que visam à adaptação do sujeito ao meio e, consequentemente, as ditas práticas homogeneizadoras foram assumidas naturalmente e de tal forma que não existe sequer a discussão de que possam ser produzidas de uma outra forma, mesmo diante do grande choque que a realidade escolar coloca perante essas práticas. Assim sendo, esses profissionais

[...] não conseguem analisar criticamente os currículos dos cursos de formação inicial e contínua que freqüentaram e neles constatar os traços monoculturais do patrimônio dominante que veicularam de forma inconteste o discurso da saúde, do esporte de rendimento, dos jogos para aprendizagem, dos métodos de ensino, das formas de condução e organização da ação educativa, etc. contaminados pelo daltonismo, seguem reproduzindo inconscientemente os mesmos discursos dos anos de formação (NEIRA; 2009, p. 28).

A abordagem pedagógica Crítico-superadora em Educação Física, ao indicar os modos de como a área tradicionalmente confere sentidos às suas práticas pedagógicas escolares - na maioria das vezes socioculturalmente irrefletidas, despolitizadas e despolitizadoras - pautando-se basicamente pelos referenciais técnico-biologicistas, esportivizantes e da aptidão física e saúde, procura demonstrar como essas perspectivas de ensino encontram-se impregnadas, ideologicamente, pelos valores hegemônicos das sociedades capitalistas, à medida que buscam, 
[...] através da educação, adaptar o homem à sociedade, alienando-o da sua condição de sujeito histórico, capaz de interferir na transformação da mesma. Recorre à filosofia liberal para a formação do caráter do indivíduo, valorizando a obediência, o respeito às normas e à hierarquia. Apoia-se na pedagógica tradicional influenciada pela tendência biologicista para adestrá-lo. Estas concepções e fundamentos informam um dado tratamento do conhecimento (COLETIVO DE AUTORES, 1992, p. 36).

A abordagem crítico-emancipatória, por sua vez, considera que as reduções pedagógicas tecnicistas em Educação Física também implicam em consequências limitantes à formação social, política e cultural dos alunos, especialmente no que diz respeito às possibilidades de autonomia e emancipação dos sujeitos nos diferentes contextos sociais.

A Educação Física limitada à prática de atividades motoras, exercícios e práticas esportivas, onde são negligenciadas as questões de desenvolvimento de autonomia e de um conjunto de repertórios e de competências sociais deve passar " [...] por uma profunda mudança, iniciando-se, esta, em seus elementos de composição básica, como o próprio esporte, o movimento, o processo ensino-aprendizagem e a relação que estes mantêm com a globalidade do Contexto Sociocultural" (KUNZ, 1991, p. 183).

Destacam-se, ainda, neste contexto de críticas, a radicalidade das apreensões que os referenciais pós-críticos oferecem à reflexão sobre as escolhas e silenciamentos encontrados no momento do desenvolvimento das práticas pedagógicas escolares da disciplina, em que, ao ignorarem, por exemplo, as práticas corporais africanas ou indígenas, "[...] dos grupos que compõem uma parcela significativa da população, veicula-se a impressão de que sua contínua condição desprivilegiada lhes é merecida" (NEIRA; NUNES, 2009, p. 236).

Através da análise de pesquisas em Educação Física Escolar desenvolvidas etnograficamente, são destacados aspectos em relação a pressupostos conceituais dos referenciais teóricos etnográficos, críticos e pós-críticos em Educação. A partir das indicações e considerações problematizadoras, que as teorias curriculares críticas e póscríticas apresentam às práticas pedagógicas escolares em Educação Física, a pesquisa denota especial interesse em relação aos modos de construção dos trabalhos etnográficos que estão sendo realizados pelos pesquisadores da área, inclusive em suas limitações, pois, como afirma Magnani (2001), 
[...] sinônimo de observação participante, confundida em outros, seja como pesquisa-ação, seja como pesquisa participante, a etnografia foi transformada num verdadeiro passe-partout sempre quando houve algum tipo de envolvimento com os pesquisados, e na maioria dos casos terminou servindo antes como um rótulo do que como efetivo instrumento de trabalho (p. 22).

Considerando-se, assim, o interesse de analisar um conjunto de relatos etnográficos escolares em Educação Física, documentados em forma de dissertações e teses escolares em Educação Física, é que as ênfases referenciais teóricas e metodológicas para este trabalho foram estabelecidas, uma vez que, se por um lado, o que se busca é melhor compreender as articulações feitas entre currículos propostos e suas efetivas realizações no campo pedagógico da Educação Física Escolar, por outro, com igual interesse, ocupa-se, também, dos aspectos que dizem respeito às formas e procedimentos de coleta, registros, análises e à elaboração de relatórios científicos etnográficos em Educação Física Escolar.

Durante o percurso de realização das atividades propostas para esta pesquisa, recaíram, inicialmente, atividades de apreensão dos elementos teóricos que permitissem analisar a constituição de relatos etnográficos, sendo que, do mesmo modo, foram constituídos quadros teóricos analíticos curriculares em Educação Física, primeiro tratando da abordagem Crítico-superadora e, em seguida, sobre o Currículo Cultural em Educação Física.

O estudo teórico sobre Etnografia conferiu ênfase às abordagens sobre parâmetros específicos, característicos das pesquisas etnográficas em Educação, considerados indicadores relevantes na orientação dos processos de análises sobre dissertações e teses escolares em Educação Física.

Os quadros teóricos curriculares Crítico-superador e Cultural em Educação Física Escolar são apresentados em seus elementos estruturantes característicos, princípios e procedimentos éticos, didático-metodológicos e avaliativos. As duas matrizes curriculares, assumidas para este trabalho, caracterizam-se por suas posturas radicalmente críticas em relação à tradição biologicista, tecnicista e esportiva da área, mas que se diferenciam em suas premissas pedagógicas e políticas, circunscritas aos campos da modernidade e pós-modernidade, respectivamente.

O banco de dados com pesquisas em forma de dissertações e teses em Educação Física Escolar, que inicialmente se propunha mais amplo de âmbito nacional, foi reduzido às pesquisas elaboradas nas três universidades estaduais públicas de São Paulo, que ao se 
autodeclararem como etnográficas em seus resumos, apresentam, em seus procedimentos metodológicos de campo, observações, entrevistas e análises documentais, uma produção de relatos a respeito de diversos temas relativos à Educação Física nas escolas.

O intuito que animou esta proposta de trabalho foi o de colaborar nas reflexões sobre a assertiva com a qual efetivamente concordamos - sobre os desafios da Educação Física escolar, em que "[...] está em jogo no momento é a definição daquilo que deve acontecer nos encontros letivos de Educação Física, em outras palavras, o que está em jogo é qual Educação Física ensinar" (NEIRA, 2011a, p.09). 


\section{ETNOGRAFIA, EDUCAÇÃO E EDUCAÇÃO FÍSICA}

De maneira geral, quando se fala em trabalho de campo, estamos falando de um processo que se inicia com o estudo dos referenciais teóricos conceituais de um dado fenômeno. Antes de iniciarmos um trabalho de pesquisa, determinam-se delimitações, o grupo a ser estudado, o local, os instrumentos que iremos utilizar e a forma de análise destes dados, que devem estar relacionados aos instrumentos que escolhemos.

Escolha esta que se dá, partindo do princípio de que as pesquisas reunidas representem de forma significativa o fenômeno que se busca entender. Em outros momentos, procura-se estabelecer e verificar possíveis correlações entre variáveis que possam dar significado a determinadas práticas sociais, assim sendo, ressalta-se que as ciências se constroem de variadas formas e métodos.

O estudo de um determinado acontecimento por si não impede que se produza conhecimento acerca do mesmo e este conhecimento estará circunscrito ao método que utilizamos para conhecê-lo e/ou compreendê-lo.

No que se refere ao trabalho de campo, valendo-se do referencial etnográfico, é preciso tentar estabelecer os diferentes aspectos conceituais que tal procedimento implica. O estudo de determinada prática social deve desenvolver-se no e a partir do contexto sócio histórico cultural onde acontece, o que significa dizer que para entendermos um determinado fato, objeto ou fenômeno social é condição que o possamos estudar inserido, contextualizado no lugar, nas relações, nos significados que justificam e mantêm a sua existência de uma determinada forma e não de outra (FONSECA, 1999).

É preciso então que o trabalho de campo tenha, entre outros objetivos, que observar as trocas, as interações sociais e que permaneça, no campo, tempo suficiente para o pesquisador atingir os seus objetivos.

Bueno (2007) destaca a importância da imersão do pesquisador junto ao objeto pesquisado, em que considera a antropologia como uma ciência que busca entender as redes de significados sociais e que, para que estas redes possam ser acessadas, dependese, de fato, da imersão do pesquisador no campo, em que a interpretação das expressões sociais só seria possibilitada com o aprofundamento do pesquisador junto aos sujeitos, em seus próprios contextos.

Ao adotar, por exemplo, a observação participante como um método privilegiado para se alcançar, ou tentar se aproximar da totalidade de um sistema, parte-se da premissa de que o sentido de uma determinada prática só poderá ser alcançado e entendido quando 
contextualizado, em que são refletidos os conjuntos de signos, de símbolos e significados expressos de determinadas culturas.

$\mathrm{Na}$ maioria dos referenciais e métodos de pesquisa, o envolvimento do pesquisador deve ser o menor possível, o que se contrapõe a priori à possibilidade de se desenvolver um trabalho etnográfico, já que o mesmo entende uma imersão do pesquisador junto à comunidade com a qual pretende conhecer/verificar determinadas questões significativas. Vai-se a campo com questões iniciais, mas no próprio campo, nas relações que vão se produzindo, surgem novas questões, que podem fortalecer as já estabelecidas a priori ou suscitar novas questões, o que implicaria em novos caminhos. Este processo é possível quando, em função da imersão no campo, se produz uma interação que parte do estabelecimento de uma confiança mútua, através dos diálogos travados (BUENO, 2007).

Esta imersão permite uma "coleta de dados" muito mais aproximada de uma realidade vivencial do sujeito, pois ela ocorre durante um processo de participação do pesquisador no movimento sociocultural "in loco", em que aspectos cognitivos, afetivos, morais e, principalmente, relacionais vão dando sentido ao que se pretende de fato apreender de um determinado grupo, de uma determinada cultura, em que "[...] muito mais do que simplesmente falar, é conversar com eles. O objetivo da Antropologia é o alargamento do universo do discurso humano" (GEERTZ, 1989, p. 10).

Assim, através desta forma de se relacionar, é possível produzir um texto em que não se tem por objetivo simplesmente dar fala a um determinado grupo ou cultura, em que não se pretende falar por eles, mas sim produzir uma série de reflexões que passa pelo processo de troca, que se produziu a partir do encontro/confronto entre o pesquisador (com sua cultura e sua história) e o 'objeto’ (também com sua cultura e sua história).

Não se pode perder de vista a importância dos referenciais conceituais em relação às análises dos dados empíricos, incorrendo no equívoco de tentar entender um processo, analisando-o a partir do senso comum e/ou das próprias representações pessoais do pesquisador. A ausência de uma “[...] articulação entre referenciais teóricos e observação poderia ocasionar um afastamento dos objetivos da etnografia" (BUENO, 2007, p.481).

O processo da produção de conhecimento se dá, então, no campo onde a postura do pesquisador deve ser bastante clara, ele se insere no grupo, entra no jogo, faz parte e se implica no processo e, no que se refere às perguntas e hipóteses, mesmo que se parta inicialmente de algum ponto norteador, no trabalho etnográfico, tem-se a clareza de que 
tais questões poderão ser alteradas como consequência dos contatos que vão sendo estabelecidos e estreitados com os sujeitos (FONSECA, 1999).

Reconhece-se, de forma quase consensual, que não existe conhecimento científico que se produza de forma isenta, que o produto de um determinado trabalho sempre será mediado por questões que passam, necessariamente, pelo sujeito que o produziu, sendo influenciado pelas suas concepções políticas e ideológicas, pela sua própria experiência de vida que o levou a determinadas escolhas.

Deste modo, Rockwell (2009) afirma que a etnografia tratada como abordagem, não deve ser tomada como instrumento neutro,

[...] como enfoque, está impregnada de concepciones implícitas acerca de como se construyem representaciones de la vida social y cómo se les dá sentido a partir del diálogo com quienes habitan una localidad. Permite comprender algunos procesos sociales y práticas culturales, especialmente a escala cotidiana, pero también encuentra límites ineludibles (p.184).

Ao se deparar com esta impossibilidade de uma postura neutra, pesquisadores tentam, através do uso de metodologias, minimizar esta "influência". Entretanto, no caso do referencial etnográfico, este fato não só não se constitui um problema, mas é de certa forma a base para o desenvolvimento do trabalho, ou seja, o trabalho irá se configurar a partir das interações e influências mútuas entre o pesquisador e o objeto de pesquisa, em que quanto maior e melhor for esta interação, maior será a compreensão do fenômeno. Contudo Caldeira (1988) sugere que o pesquisador que se utiliza do referencial etnográfico deve estar atento para reproduzir a sua experiência no campo tal qual a mesma se deu, sendo o máximo possível fiel na sua descrição.

Bueno (2007) afirma que, em relação à etnografia nos processos educacionais, alguns autores, a partir dos anos 80, como Rockwell e Ezpeleta, vão apresentá-la numa perspectiva de produção de transformação, atentando para o fato de que nas pesquisas etnográficas sejam buscadas novas possiblidades de relação com a escola e com o trabalho dos professores, que de acordo com as pesquisadoras a "[...] a transformação mais importante que a etnografia pode obter é aquela que se opera naqueles que a praticam" (BUENO, 2007, p. 486).

$\mathrm{Na}$ presente pesquisa, a Etnografia em Educação cumpre, entre suas principais finalidades, problematizar os campos metodológicos nas investigações sobre Educação 
Física Escolar, tanto em relação às elaborações dos relatos, quanto dos próprios procedimentos pedagógicos evidenciados, indagando sobre aspectos relativos às escolhas dos pesquisadores em suas motivações e justificativas iniciais; definições sobre o trabalho de campo, quantidade de tempo no processo de coleta de dados, critérios para coleta e análise dos dados; redação, características e apresentação dos resultados.

No quadro Etnografia em Educação Física, quatro componentes são apresentados na composição dos eixos estruturantes para análises das dissertações etnográficas: identificação; pontos de partida/metodologia; em campo, tempo, técnicas, registros; no texto: características e procedimentos de análises.

Estes componentes centrais estão circunscritos por um conjunto de questões norteadoras, para identificação dos trabalhos, como sobre quem são os autores e orientadores de teses etnográficas escolares em educação física e quais programas de pósgraduação em Educação ou Educação Física foram desenvolvidos. O segundo componente refere-se aos Pontos de partida, com o interesse de compreender quais aspectos o pesquisador leva a campo em suas questões iniciais, concepções e pré-noções,

Entendendo que o pesquisador leva para campo suas pressuposições, seus preconceitos, suas formas de se relacionar e compreender a sociedade da qual faz parte e na qual se localiza o seu campo de pesquisa, é importante que o texto final apresente claramente os pontos de vista que se constituíram, portanto, em pontos de partida para a realização da investigação. Esta é uma exigência importante que decorre do fato de que os etnógrafos são membros da sociedade que estudam, diferentemente dos antropólogos que, em outros tempos, estudavam sociedades estranhas (BRAGA, 2001, p. 67).

Rockwell (2009) alerta sobre os impasses que ocorrem ao pesquisador, com o impacto do surgimento de questões de ordem metodológicas e pessoais, logo nos primeiros momentos de entrada em campo,

[...] estar en el campo lleva inevitablemente a la pregunta '¿qué hacemos ahí?'. No pocos que intentan responder a esta pregunta en sus primeras exploraciones sobre el terreno han dado la media vuelta y han regresado a la biblioteca o al archivo o, ahora, a internet. Permanecer ahí puede ser difícil, inquietante, desconcertante (p.186).

Sobre a metodologia busca-se identificar os modos de como o pesquisador relaciona e articula o referencial específico teórico, instrumental e analítico etnográfico 
com seu tema de pesquisa, pois como afirmam Ezpeleta e Rockwell (2007) esta "[...] tradição de pesquisa, quando não se arrogam pretensões ateóricas ou não se situa dentro de sua vertente empirista, permite integrar ao processo de pesquisa o necessário desenvolvimento conceitual" (p.146) .

Como terceiro componente deste eixo, são considerados os itens em relação ao trabalho de campo: tempo/técnicas/registros. No trabalho de campo, compreende-se o processo em que se devem fornecer elementos que alterem as predisposições iniciais do pesquisador, como considera Rockwell (1987), a partir de suas próprias experiências,

[...] el análisis etnográfico es un trabajo específico que conduce a la construcción de nuevas relaciones, no previstas antes de hacer el análisis. Según esta definición, se ha hecho análisis cuando las concepciones que se tuvieron acerca del objeto de estudio al inicio del estudio resultan transformadas (modificadas, complejizadas, condicionadas, determinadas, etc.) en alguna medida (p.10).

No que diz respeito ao tempo, refere-se a uma apreensão tanto quantitativa quanto qualitativa da relação do pesquisador e seus períodos passados em campo, considerandose como afirma Braga (2001) que

[...] dos elementos diferenciadores entre a etnografia e outras formas de pesquisa qualitativa é, segundo muitos autores, a longa permanência dos pesquisadores em campo, (...) a exigência de um trabalho de campo prolongado é um dos pontos sobre os quais parece haver consenso ao se avaliar uma etnografia (p. 164).

Quanto às técnicas de coleta de dados utilizadas, o interesse se volta tanto para os diferentes procedimentos instrumentais de coleta quanto para as análises e adequações suscitadas, desde os períodos iniciais em campo, considerando que

[...] ainda que observar, registrar, gravar, entrevistar sejam formas das quais os etnógrafos lançam mão para construir suas investigações, não é apenas isso que caracteriza e define a etnografia. De outro lado, embora a produção de documentos descritivo-analíticos de particularidades de uma cultura seja finalidade da etnografia, seu sentido também não se esgota nesse produto (BRAGA, 2001, p. 177).

Rockwell (2005), ao se referir sobre os processos de observação, entendida como interacional, chama a atenção para o fato de esta estar repleta de suposições teóricas, 
culturais e ideológicas, em que de "[...] ninguna manera es posible elaborar una cartografía completa de la "otra cultura" y, de hecho, los significados logrados están imbuidos de los supuestos culturales tanto del investigador como de las personas con quienes conversa" (p. 05).

Finalizando este tópico, apresentamos o item registro, no qual é enfatizada a elaboração do diário de campo, os procedimentos concomitantes e judicativos durante a coleta de dados, encaminhamentos, alterações, dúvidas, redirecionamentos,

O etnógrafo, ao escrever e ler seu diário de campo, "além de 'esboçar' o outro, 'esboça-se' também como personagem de seu empreendimento" já que a forma como esteve imerso naquele conjunto de significados que procura investigar já é, ela mesma, possuidora de múltiplos sentidos, dos quais apenas alguns serão privilegiados na escrita, como resultados dos processos seletivos que o investigador inexoravelmente fará (BRAGA, 2001, p. 211).

É importante ainda abordar a ideia que se refere à "comunicação sincera" pois como Rockwell (2009) afirma, seria ao "[...] entablar conversaciones sinceras en torno de intereses comunes es la base del processo de transformacion personal, es decir, el meollo de la etnografia. Narrar esta experiencia le da sentido a lo que suele llamarse el diario de campo" (p. 191).

Quanto às especificidades metodológicas contidas nos processos de construção dos relatos, (variáveis segundo os ciclos e anos de escolarização), quando referidas especialmente à observação participante junto a crianças, utilizando o exemplo dado por Florestan Fernandes acerca de um trabalho por ele desenvolvido, em que, entre outras coisas, o mesmo viabiliza a escuta das observações e críticas das crianças, Demartini (2009) destaca a importância de que sejam ouvidas, para que se saiba o que pensam, dizem, realizam, “[...] naquela época, ele já recorria às criticas das crianças sobre aquilo que ele estava refletindo. Nós usamos pouco as falas das crianças e menos ainda as críticas das crianças (p. 10)" .

$\mathrm{Na}$ triangulação metodológica clássica etnográfica, observação/entrevista/análise documental, a autora, ao se referir ao último item, destaca a importância de se coletar e dar valor à documentação escrita e iconográfica das crianças, inclusive os escritos autobiográficos, que podem fornecer importantes elementos sobre uma determinada composição da cultura infantil, de determinados períodos, em diferentes realidades, de 
como foram/são construídas, sentidas, pelas crianças-protagonistas/informanteslegítimas, pois se deve compreender que,

[...] os escritos autobiográficos como os diários são importantes (...) a escrita autobiográfica da própria criança ganha especificidades que a diferenciam daquela que é escrita ou narrada pelo autor após toda uma trajetória de vida, na idade adulta: ela nos aproxima da criança, de seus pensamentos e sentimentos no momento vivenciado (DEMARTINI, 2009, p. 20).

Como último componente deste eixo estruturante do quadro referencial de análises etnográficas em Educação Física, damos especial atenção à constituição final da pesquisa, em forma de seu texto, suas características e modos de análises,

[...] constitui-se como elemento identificador da etnografia, a produção de um texto em que a riqueza e a complexidade das observações sejam preservadas no conjunto das análises feitas pelo pesquisador, e que a experiência de campo seja explicitada sem perder suas características essenciais, como a historicidade, por exemplo. Desse ponto de vista, entende-se que estarão presentes no texto tanto o sujeito pesquisador como os sujeitos envolvidos, denominados frequentemente informantes e, mais recentemente, interlocutores ou participantes (BRAGA, 2001, p. 80).

Peirano (1992) destaca que é importante perceber que as pesquisas nas chamadas ciências humanas se produzem, principalmente, na interface entre o conhecimento empírico (aquele que se produz no senso comum) e o conhecimento técnico/científico, numa relação dialética. Na Antropologia, essa relação se daria de forma ainda mais estreita:

A antropologia tem como projeto formular uma ideia de outros povos e outros lugares. A antropologia tem como projeto formular uma ideia de humanidade construída pelas diferenças, resultado e contraste dos nossos conceitos (teóricos ou do senso comum) com outros conceitos nativos. Se este feedback entre pesquisa e teoria constitui o procedimento básico do conhecimento científico em geral, ele assume uma dimensão mais dramática na antropologia, pois que nela a pesquisa tem como característica ser pesquisa de campo (PEIRANO, 1992, p. 04). 
Entretanto deve-se ter em conta que a partir de uma crítica pós-moderna feita aos textos etnográficos aponta-se que a etnografia “[...] não deve ser uma interpretação sobre, mas uma negociação com, um diálogo, a expressão das trocas entre uma multiplicidade de vozes" (CALDEIRA, 1988, p.141).

Geertz (1989), no que diz a respeito do registro etnográfico, afirma a importância deste se constituir em mais do que um conjunto detalhado, minucioso e sequencial de acontecimentos, mas sim se constituir como uma 'descrição densa',

Lo que en realidad encara el etnógrafo (salvo cuando está entregado a la más automática de las rutinas que es la recolección de datos), es una multiplicidad de estructuras conceptuales complejas, muchas de las cuales están superpuestas o enlazadas entre sí, estructuras que son al mismo tiempo extrañas, irregulares, no explícitas, y a las cuales el etnógrafo debe ingeniarse de alguna manera, para captarlas primero y para explicarlas después. Y esto ocurre hasta en los niveles de trabajo más vulgares y rutinarios de su actividad: entrevistar a informantes, observar ritos, elicitar términos de parentesco, establecer límites de propiedad, hacer censo de casas... escribir su diario. Hacer etnografía es como tratar de leer (en el sentido de "interpretar un texto") un manuscrito extranjero, borroso, plagado de elipsis, de incoherencias, de sospechosas enmiendas y de comentarios tendenciosos y además escrito, no en las grafías convencionales de representación sonora, sino en ejemplos volátiles de conducta modelada (p. 26).

Entende-se que, a partir do enfoque da Antropologia, a Educação Física tem visto a si mesma de uma forma mais dinâmica, ampliando seus horizontes, levando à busca de uma compreensão das diferenças produzidas pelas diferentes culturas corporais, em múltiplos contextos,

A perspectiva antropológica lança luzes sobre essa área chamada Educação Física, área esta que é, simultânea e dialeticamente, única e variada, singular e plural, objetiva e subjetiva, universal e local. Qualquer abordagem de Educação que negue esta dinâmica cultural inerente à condição humana correrá o risco de se distanciar do seu objetivo último: o homem como fruto e agente da cultura. Correrá o risco de se desumanizar (DAOLIO, 2001, p. 38).

Braga (2001) destaca em sua pesquisa o modo de como dois dos orientadores de dissertações e teses, por ela identificados com mais trabalhos autodenominados etnográficos em Educação, posicionam-se em relação ao conjunto de suas próprias 
orientações e pesquisas com essa denominação, pois como Luiz Carlos de Freitas ${ }^{1}$ professor do Programa de Pós-Graduação em Educação da Universidade Estadual de Campinas (PPGE/UNICAMP) teria esclarecido, “[...] de forma bastante incisiva que, rigorosamente, nenhum dos trabalhos que ele orientou pode ser chamado de etnográfico [...] os trabalhos que fazemos são estudos de caso, com alguma influência etnográfica, do ponto de vista das técnicas envolvidas" (p. 152).

Em relação ao posicionamento de Magda Soares professora do Programa de PósGraduação em Educação da Universidade Federal de Minas Gerais (PPGE/UFMG), seus argumentos também parecem corroborar com o sentido expresso por Freitas, em relação às pesquisas etnográficas em Educação de forma mais geral, pois ela

[...] ressalta que faz restrição em denominar de 'etnográficas' as pesquisas que orientou. Considerou que, pelas características, elas exigiram uma aproximação etnográfica, com utilização de recursos próprios da etnografia. Magda Becker Soares julga que se pode dizer a mesma coisa da maior parte das pesquisas que se dizem etnográficas (BRAGA, 2001, p. 152).

Deste modo, é importante ratificar que nosso interesse pela Etnografia recai tanto em suas finalidades de pesquisa acadêmica, mas como atividade inerente à própria prática pedagógica, pois de acordo com Neira (2011b), quando considerado o Currículo Cultural da Educação Física colocado em ação,

Em meio ao processo de desmantelar as forças ideológicas, os docentes empregam a etnografia como forma de conferir aos alunos e a si próprios à condição de etnógrafos. Dessa forma, professor e estudantes debruçam-se na leitura e na interpretação dos múltiplos aspectos envolvidos na prática cultural corporal objeto de estudo. A execução satisfatória da etnografia exige que todos os envolvidos realizem investigações individuais ou coletivas (p. 119).

Assim esta pesquisa sobre etnografias escolares em Educação Física, estão compreendidas como processos dialéticos de leituras e interpretações das realidades

\footnotetext{
${ }^{1}$ O professor integra, como líder, o grupo de pesquisa cadastrado no Sistema Lattes-CNPq, com o nome de Laboratório de Observação em Estudos Descritivos, do qual também faz parte a professora Mara Regina Lemes de Sordi, responsável também pela orientação de dois trabalhos autodenominados etnográficos, localizados na base de dados da ANPED. O grupo, com mais de dez anos de existência, prioriza a análise da avaliação tomando-a como elemento central na prática pedagógica (Sistema Lattes-CNPq). (BRAGA, 2001).
} 
escolares, nas relações estabelecidas entre pesquisadores (as) e professores (as), alunos (as) e comunidade escolar.

Em seguida, serão abordados aspectos específicos de dois conjuntos referenciais curriculares em Educação Física: o Crítico-superador e o Cultural. A escolha destas duas matrizes curriculares dá-se em função, no primeiro caso, a Crítico-superadora, por conta de sua orientação marcadamente moderna, alicerçada nos fundamentos teóricometodológicos dialético-materialistas da Pedagogia Histórico-Crítica, assim como, no caso da segunda matriz, a Cultural, incluir em seus fundamentos estruturantes, abordagens de elementos e conceitos dos Estudos Culturais e do Multiculturalismo Crítico, alinhados ao campo epistemológico da Pós-Modernidade.

\subsection{CRÍTICO-SUPERADOR}

A estrutura teórico-metodológica do currículo Crítico-superador, aqui entendido, apresenta em suas determinações cinco componentes principais: Prática social inicial; Problematização; Instrumentalização; Catarse; Prática social final. De orientação teórica marxista, circunscreve suas bases conceituais no campo da História, do materialismo-dialético, da luta de classes, do capitalismo, da Política, da Educação e da transformação social.

Como primeiro item encontra-se a prática social inicial, situação didática em que se procuram evidenciar os objetivos, conteúdos e procedimentos metodológicos e avaliativos, além das relações compreendidas entre a disciplina, o conteúdo, sua forma de abordagem e o mundo social.

Ganham importância as apreensões que os alunos sentem em relação aos temas apresentados, como estão inseridos em suas vidas, no mundo do trabalho, do lazer, da religião, da política, da família, da comunidade, em que no “[...] anúncio dos conteúdos aponta-se o que será estudado e quais os objetivos a serem alcançados. Na vivência cotidiana dos conteúdos, identifica-se o que os alunos já sabem e o que eles gostariam de saber mais sobre o assunto em questão" (REIS, et al. 2013, p.58).

Sendo a prática social inicial uma contextualização do conteúdo, os diálogos que passam a ser estabelecidos entre professores e alunos remetem a uma construção coletiva inicial sobre o tema em suas múltiplas relações. A apresentação dos objetivos e conteúdos é feita a partir do elaborado nos programas oficias, instituição e docentes. 
Na prática, o anúncio dos conteúdos realiza-se quando se informam aos alunos quais tópicos e subtópicos serão abordados nas próximas aulas. É a listagem dos temas a serem desenvolvidos com seus respectivos objetivos. Esse procedimento auxilia os educandos a assumirem o encaminhamento do processo pedagógico (REIS et al., 2013, p. 24).

Como segundo elemento deste quadro curricular, apresenta-se a problematização, entendida como tarefa em que são colocadas questões centrais específicas do conteúdo em relação às suas dimensões e finalidades sociais, o que atribui à abordagem do conhecimento nesta perspectiva, uma constante de possibilidades e reelaborações. Considerado 'fio-condutor' de todo o processo esse “[...] momento é ainda preparatório, no sentido de que o educando, após ter sido desafiado, provocado, despertado e ter apresentado algumas hipóteses de encaminhamento, compromete-se teórica $\mathrm{e}$ praticamente com a busca da solução para as questões levantadas” (REIS et al., 2013, p. $60)$.

O terceiro item deste eixo é denominado instrumentalização tomada no sentido expresso por Gasparin (2007), como sendo o centro do processo pedagógico da proposta didática histórico-crítica, em que são desenvolvidas práticas e estratégias para que o conhecimento abordado seja tanto apropriado, quanto aplicado e transformado pelo aluno. Considerada a fase em que os conceitos científicos passam a ser mais bem assimilados, em que as abstrações são estabelecidas em maiores nexos e segurança no entendimento e construção da realidade - o concreto pensado -, seria, neste momento, que se realizaria a aprendizagem.

Por isso, o trabalho do professor como mediador consiste em dinamizar, através das ações previstas e dos recursos selecionados, os processos mentais dos alunos, para que se apropriem dos conteúdos científicos em suas diversas dimensões, buscando alcançar os objetivos propostos ( $\mathrm{p}$. 127).

Como quarto elemento encontra-se a catarse, em que pontos de chegada e níveis atingidos são expressos por demonstrações teóricas. De acordo com Saviani (2006), este seria considerado um momento de produção e materialização avaliativa do processo, “[...] o momento de expressão elaborada da nova forma de entendimento da prática social a que se ascendeu [...] trata-se da efetiva incorporação dos instrumentos culturais, transformados agora em elementos ativos de transformação social” (p. 72). 
Finalizando a composição deste quadro curricular, encontra-se o item, prática social final do conteúdo, momento em que seria expressa uma tomada de consciência para ação social ampliada, modificada, em que se teria uma,

[...] nova maneira de compreender a realidade e de posicionar-se diante dela: é a manifestação da nova postura prática, da nova atitude, da nova visão do conteúdo no cotidiano. Trata-se, de acordo com Gasparin (2005), do momento de ação consciente em prol da transformação da realidade, a partir do retorno à prática social, agora entendida de forma mais elaborada (REIS et al. 2013, p. 61).

Dada a intenção de formar uma nova mentalidade, com condições de analisar, apreender, criticar os contextos em suas múltiplas determinações, em função das mediações realizadas no processo dialetizado de ensino-aprendizagem proposto,

[...] ações reais e efetivas não significam somente realizar atividades que envolvam um fazer predominantemente material, como plantar uma árvore, fechar uma torneira, assistir a um filme etc., uma ação concreta, a partir do momento em que o educando atingiu o nível do concreto pensado, é também todo o processo mental que possibilita análise e compressão mais amplas e críticas da realidade, determinando uma nova maneira de pensar, de entender e julgar os fatos, as ideias. É uma nova ação mental (GASPARIN, 2007, p. 146).

A apropriação pelos alunos do conhecimento científico, considerado socialmente relevante, a apreensão de suas sínteses e contradições, orientadas para a construção de condições objetivas e subjetivas para a transformação social, explícita em seus determinantes teóricos e, principalmente, políticos, o compromisso com os interesses dos trabalhadores proletários, inseridos nos conflitos e antagonismos característicos das sociedades divididas em classes sociais distintas.

Esse conjunto teórico ao qual se referem as propostas de encaminhamentos didático-metodológicos de uma Pedagogia Histórico-Crítica para Educação Física Escolar - estruturada a partir das proposições de trabalhos como os de Reis et al (2013), Coletivo de Autores (1992), Gasparin (2007), Saviani (2006), - reafirmam a importância da competência técnica aliada à política nos aspectos que dizem respeito às práticas pedagógicas nas aulas de Educação Física na abordagem 'Crítico-superadora'. 


\subsection{CURRÍCULO CULTURAL}

Na constituição do Currículo Cultural em Educação Física, os componentes didático-metodológicos foram o Mapeamento, a Problematização/Tematização, a Genealogia Arqueológica e o Registro e Avaliação.

Compreendido e assumido numa acepção pós-moderna, orientado pelas teorias pós-críticas, o Currículo Cultural propõe uma ação pedagógica orientada pela Justiça Curricular, com a formação de sujeitos comprometidos com identidades democráticas, em que as relações de poder, o Outro e o trato das diferenças são tematizados, problematizados e sistematizados pedagogicamente nas aulas de Educação Física das escolas.

Com base na justiça curricular, é possível inferir que uma distribuição equilibrada das diversas manifestações da cultura corporal, a partir do seu grupo social de origem prestigia, pela valorização do patrimônio cultural corporal tradicionalmente excluído do currículo, a pluralidade dos grupos presentes na escola e na sociedade. Essa medida visa romper com a exclusividade de valores que intensificam noções de superioridade/inferioridade que atribuem conotações discriminatórias aos setores sociais em desvantagem nas relações de poder (NEIRA, 2011b. p. 69).

O princípio Justiça Curricular remete à importância de serem considerados os múltiplos saberes sobre a cultura corporal que perpassam a escola, através das inúmeras manifestações corporais apresentadas pelos alunos, pelos docentes e comunidade escolar. Nesse sentido, a consideração sobre a relevância dos diferentes saberes passa a permear a elaboração do Currículo Cultural, um currículo que segundo Neira (2011b)

[...] elaborado de forma justa mantém-se atento ao modo como se privilegiam certos conhecimentos em detrimento de outros, certos discursos em detrimento de outros, certas vozes em detrimentos de outras, atuando no sentido de modificar as condições de minimização e desqualificação das temáticas pertencentes aos grupos não hegemônicos (p. 69).

O trabalho pedagógico sobre o conhecimento - com seus valores, interesses, necessidades, desejos - é passível de análises, críticas, questionamentos, que dizem respeito aos sujeitos do saber, suas inúmeras determinações, múltiplos antagonismos, 
diversas correlações de poder, econômicas, políticas, religiosas, de classe, gênero, étnicas, entre outros tantos marcadores sociais identitários-diferenciadores, daí residira a importância dada,

[...] a uma distribuição equilibrada das diversas manifestações da cultura corporal, a partir do seu grupo social de origem, prestigia, pela valorização do patrimônio cultural corporal tradicionalmente excluído do currículo, a pluralidade dos grupos presentes na escola e na sociedade (NEIRA, 2011b, p. 69).

Assim, os saberes silenciados também passam a ter condições de protagonismo, assumindo as possibilidades de conflitos como instrumento de intervenções, aprofundamento e ampliação dos saberes e não sínteses esclarecedoras ${ }^{2}$ a serem apaziguadas, banidas, evitadas. Decorre então o valor da reflexão, da análise e do exercício de formulação de hipóteses e proposições. Ações lúdicas, mimetizadas ou de reinvenções, intervenções, bricolagens, artistagens, em que se possa buscar “[...] romper com a exclusividade de valores que intensificam noções de superioridade/inferioridade que atribuem conotações discriminatórias aos setores sociais em desvantagem nas relações de poder" (NEIRA, 2011a, p. 98).

O estabelecimento da Justiça Curricular exige o reconhecimento problemático da existência do Outro, do diferente, do contraditório e conflituoso, do subjugado, hierarquizado, banido, excluído, com todas as implicações e significados para o exercício de uma pedagogia que não se omite, nem deixa de se posicionar, politicamente, sobre o conjunto de correlações de formas, forças e poderes estabelecidos, muitas vezes, opressor e autoritário contido nos saberes, colocados em xeque, quando autointitulados libertadores, emancipadores, empreendedores, evangelizadores com suas normatizações, técnicas de indução-punição de condutas.

\footnotetext{
${ }^{2}$ As teorias pós-críticas, enquanto tributárias ao referencial pós-moderno, rechaçam uma possível condição emancipatória in extremis, investindo muito mais numa construção genealógico-arqueológica da relação saber - poder entre os sujeitos-instituições e na provisoriedade processual da verdade. Algumas ainda afirmam a total impossibilidade sobre o estabelecimento de verdades, sendo estas sempre um devir-relativo, tecidas nas correlações de força e poder, provisórias, em disputa e jamais dadas a priori.
} 
As atividades de ensino atentas à justiça curricular promovem, entre outras situações, a desconstrução da maneira hegemônica de descrever o outro cultural (SILVA, 2000). No entender de Costa (2012, p.140), desconstruir não é destruir, desconstruir requer procedimentos de análises do discurso 'que pretendem mostrar as operações, os processos que estão implicados na formulação de narrativas tomadas como verdades, em geral, tidas como universais e inquestionáveis'. A desconstrução põe a nu as relações entre discursos e poder (NEIRA, 2011b, p. 70).

O mapeamento, na constituição desta prática pedagógica assim orientada, constitui o momento inicial na elaboração do planejamento do professor no processo de construção e desenvolvimento de suas aulas.

No sentido de reconhecer e valorizar a cultura corporal acessada, é feito um levantamento sobre quais as apreensões que os alunos possuem acerca de suas próprias práticas culturais ligadas aos esportes, danças, lutas, ginásticas e brincadeiras ou veiculadas pelas mídias e também existentes na comunidade, ao redor e para além dos muros da escola.

Mapear quer dizer identificar quais manifestações corporais estão disponíveis aos alunos, bem como aquelas que, mesmo não compondo suas vivências, encontram-se no entorno da escola ou no universo cultural mais amplo. Mapear também significa levantar os conhecimentos que os alunos possuem sobre uma determinada prática corporal. Não há um padrão ou roteiro obrigatório a ser seguido, durante o mapeamento, os professores empreendem várias atividades (NEIRA, 2011b, p.107).

Esse procedimento de mapear é que permitirá entretecer, inicialmente, os saberes sobre a cultura corporal trazidos às escolas - contidos nas comunidades - e suas possibilidades de diálogos em relação às diferentes abordagens, tanto técnicas, de execuções de seus movimentos básicos e regramento, fundamentais, avançados, táticos, estratégicos, com implicações anátomo-fisiológicas, cinestésicas e psicológicas, mas também sociais, culturais, refletidos sobre o binômio Identidade-Diferença, diante de inúmeros marcadores sociais como posição de classe, orientações religiosas, etnia, gênero, entre outros.

O contexto problemático compreendido se estabelece socialmente quando se constata o enorme contingente de sujeitos, em seus grupos e comunidades, que possuem 
cada vez maiores dificuldades, quando não quase total impossibilidade, de se fazerem ouvidas e prevalecidas suas vozes, histórias e interesses. Por essa razão, “[...] os Estudos Culturais sempre estão do lado do mais fraco" (NEIRA; NUNES, 2009, p.192).

A tematização e a problematização, derivam das informações e dados coletados, durante o mapeamento sobre as atividades e saberes da cultura corporal na escola,

[...] na abordagem de um determinado tema, os professores emaranham as próprias culturas corporais experienciais e as dos alunos com outros saberes (acadêmicos, do senso comum, populares ou pertencentes a outros grupos). No bojo dessa triangulação, obtém-se a produção de novos sentidos para as manifestações corporais tematizadas (NEIRA, 2011b, p. 102).

A Problematização dos discursos e significados atribuídos às práticas corporais definidas em acordo com o mapeamento, articulado aos documentos oficias, ancorando socialmente seus conhecimentos e dialogando, pedagogicamente, com as manifestações da cultura corporal local emergidas, indica a exploração dos significados e as possibilidades de impressão de sentidos, em relação aos fenômenos da cultura referentes às brincadeiras, danças, lutas, ginásticas e esportes,

A problematização implica um constante desvelo da realidade percebida. É um esforço permanente por meio do qual as pessoas passam a perceber como as coisas estão no mundo (MIZUKAMI, 1986). Quando problematiza os temas da cultura corporal, o currículo se transforma em espaço de crítica cultural (MOREIRA e MACEDO, 2001), no qual se propicia o questionamento sobre tudo que possa ser 'natural e inevitável'. A ideia é colocar em xeque e permitir novos olhares sobre aquilo com que usualmente lidamos de modo acrítico (NEIRA, 2011b, p.117).

Como terceiro item deste quadro, destaca-se a Genealogia-Arqueológica, que como método, segundo Neira (2011b), “[...] fornece aos envolvidos a possibilidade da análise dos contextos de pensamento e do conjunto de verdades que validam ou negam as manifestações culturais" (p. 96).

Como último elemento deste quadro referente ao Currículo Cultural, define-se o item Registro e Avaliação, em que a importância da materialização dos procedimentos colocados em ação pelo Currículo Cultural é ressaltada, uma vez que no "[...] decorrer das atividades de ensino, as anotações das observações e análises do cotidiano das aulas 
possibilitam a reunião das informações necessárias para a avaliação do trabalho pedagógico" (NEIRA, 2011a, p. 158).

Compreendendo a avaliação como elemento integrante de todo o processo pedagógico, Neira (2011b) afirma que o Currículo Cultural compreende a produção material realizada pelos alunos em uma integralidade, em que a "[...] coleta de dados sobre o processo subsidia a reflexão a respeito da prática educativa e acumula indícios, tanto dos acertos, quanto dos possíveis equívocos pedagógicos cometidos no decorrer do processo" (p. 158).

A avaliação, nesta perspectiva, orienta-se pelo reconhecimento das diferenças culturais no ambiente escolar e fora dele, evitando a conformação de identidades cristalizadas, estigmatizantes, preconceituosas, pois compreendida de modo multicultural "[...] a avaliação volta-se ao reconhecimento da diversidade cultural e da construção das diferenças, também, no interior da sala de aula. Busca conhecer e levar em conta essa diversidade e não somente classificar os alunos" (NEIRA, 2011b, p. 160).

$\mathrm{Na}$ avaliação, é importante ressaltar que no entendimento de uma pedagogia multiculturalmente orientada e atenta às diferenças, as assimetrias de poder, a hegemonização de determinadas práticas corporais em detrimento de outras no interior da escola,

[...] ao finalizar o estudo sobre uma manifestação corporal específica, o professor pode organizar uma atividade avaliativa visando descobrir, em que medida, os procedimentos didáticos adotados naquele período letivo contribuíram para ampliar o repertório dos conhecimentos do grupo, bem como para superar os preconceitos e concepções identitárias, incialmente, reveladas (NEIRA, 2011b, p.161).

É preciso ainda que se acrescente no contexto de princípios e procedimentos do Currículo Cultural em Educação Física, como estruturado e apresentado por NEIRA (2011b), outros elementos também considerados fundamentais para o conjunto de análises sobre o trato pedagógico em seus procedimentos didático-metodológicos a respeito da Cultura Corporal na escola, tais como: o daltonismo cultural, a descolonização do currículo, sua ressignificação, aprofundamento e ampliação.

Como afirmam Stoer e Cortesão (1999), o 'daltonismo cultural' decorre da desconsideração das diferentes culturas que compartilham o espaço escolar, ratificadas por ações formativas que enfatizam a homogeneização e uniformidade dos alunos. 
Para evitar o daltonismo cultural e suas consequências, o currículo cultural empreende atividades que permitem lidar com a heterogeneidade da cultura corporal: a assistência a vídeos, modos variados de participar das vivências corporais, construção de blogs, filmagens e fotografias realizadas pelos alunos, análises de textos e imagens presentes nas mídias, elaboração de clipes, atividades partilhadas com outras escolas, demonstrações durante as aulas, estudos do meio, construção de materiais, preparação e realização de entrevistas, conversas com convidados, elaboração de apresentações para a comunidade e realização de pesquisas (NEIRA, 2011b, p. 90).

Daí a importância de se empreender uma 'descolonização do currículo', no qual as manifestações culturais dos grupos historicamente ausentes no cenário escolar passam a ser consideradas, respeitadas e abordadas, pedagogicamente, nas aulas de educação física.

A descolonização do currículo viabiliza um leque de oportunidades 'diferentes', proporcionando a participação equitativa das múltiplas identidades, aspecto central de uma escola comprometida com a apropriação crítica da cultura corporal por parte de todos os seus frequentadores. Por meio desse procedimento, o currículo cultural da educação física empreende a possiblidade de diálogo entre culturas de convivência e partilha coletiva com o diferente, desestabilizando a noção de que existem culturas particulares autênticas (NEIRA, 2011b, p. 81).

Neira (2011 a ) entende que o estabelecimento do objetivo de ressignificar o currículo parte da ideia de que sejam atribuídos novos significados aos artefatos produzidos em outros contextos, tomando como referência a própria experiência cultural; desse modo, são entendidas que as mais diversas manifestações da cultura corporal produzidas em diferentes contextos sócio-histórico-políticos, com finalidades específicas, assim como seus sentidos e significados, são elas mesmas, processos de ressignificação, transformações, em função da inter-relação com a cultura.

Ao valorizar as atividades de ressignificação, o currículo da Educação Física favorece a construção de identidades democráticas por meio da troca entre crianças, entre as crianças e o professor, a aceitação das diferenças e o respeito ao outro. Os indivíduos se reconhecem e se diferenciam a partir do outro, por isso as atividades devem possibilitar a participação, independentemente das características individuais ( $\mathrm{p}$. 157). 
Dentro do quadro teórico referencial do Currículo Cultural em Educação Física, são considerados os procedimentos de aprofundamento e ampliação em que, segundo Neira (2011a),

\begin{abstract}
Aprofundar, aqui, significa conhecer melhor a manifestação corporal objeto de estudo. Procurar desvelar aspectos que lhe pertencem, mas que não emergiram nas primeiras leituras e interpretações. Ampliar, por sua vez, implica em recorrer a outros discursos e fontes de informação, preferivelmente, aqueles que trazem olhares diferentes e contraditórios com as representações e discursos acessados nos primeiros momentos (p. 158).
\end{abstract}

Desse modo são abordadas possíveis modificações de sentidos, transformações quanto à percepção e entendimento dos temas da cultura corporal, problematizados na (s) aula(s) em relação aos conhecimentos e apreensões iniciais. Na ampliação, busca-se o entretecimento de saberes entre o específico - o tema da cultura corporal desenvolvido nas aulas - e reflexões sobre seus nexos em diferentes âmbitos tais como: econômicos, políticos, midiáticos, religiosos, artísticos, étnicos raciais, de gênero, de orientação sexual, entre outros.

Os educadores que atuam inspirados pelos valores do currículo cultural reescrevem diariamente e durante as aulas uma nova prática pedagógica de cunho democrático. McLaren (1997a) ensina que essa redação inovadora leva à inclusão dos conhecimentos das manifestações da cultura corporal dos grupos subordinados e a uma nova perspectiva dos olhares dos alunos sobre si próprios e sobre seu grupo, possibilitando uma prática em constante fluxo entre o local e o global, entre a comunidade e a sociedade mais ampla. No currículo cultural, os educadores medeiam o processo e fazem com que os alunos percebam os hibridismos e mestiçagens, tornando-se, eles próprios, pesquisadores do cotidiano (NEIRA, 2011a, p. 57).

Com a elaboração desses quadros curriculares - assim como o Etnográfico em Educação Física Escolar -, procurou-se delimitar os parâmetros indicativos de critérios para análises das pesquisas etnográficas escolares na disciplina de Educação Física. A seguir, serão apresentados os procedimentos e resultados parciais sobre a relação preliminar de dissertações e teses sobre Educação Física Escolar, objeto para análise de seus resumos e, posteriormente, conteúdos completos. 
Considerando as questões acima apresentadas, esta pesquisa teve por objetivos revisar os aportes teórico-conceituais e metodológicos da Etnografia, dos currículos Crítico-superador e Cultural em Educação Física; identificar, analisar, caracterizar, classificar e categorizar teses e dissertações etnográficas em Educação Física Escolar e destacar e confrontar aspectos significativos das pesquisas escolares em Educação Física considerando-se as apropriações feitas aos referenciais teóricos etnográficos e curriculares. 


\section{MÉTODO}

Em termos metodológicos, recorreu-se à análise documental, com o levantamento de dissertações e teses, por meio de elaboração de banco de dados com pesquisas escolares em Educação Física, tendo como critério principal o de serem autodeclaradas etnográficas em seus resumos.

A mudança da busca pela constituição de bancos com pesquisas etnográficas em Educação Física por todo o território nacional, para somente as restritas às universidades públicas paulistas, ocorreu em função de indicativos dos membros da banca de qualificação, em que fragilidades e desatualizações nos bancos consultados haviam sido constatadas. Trabalhos etnográficos, reconhecidos pelos membros como relevantes e com as características determinadas para esta pesquisa, como escolares, envolvendo práticas pedagógicas, refletindo sobre questões curriculares, estariam ausentes do material apresentado.

Partiu-se para elaboração de um banco de dados a partir das três universidades estaduais paulistas, retomando o critério exclusivo de se autodeclararem etnográficas em seus resumos. Foram encontradas pesquisas na Universidade de São Paulo (USP) e na Universidade Estadual de Campinas (UNICAMP), não tendo sido encontrada nenhuma ocorrência na Universidade Estadual Paulista “Júlio de Mesquita Filho”(UNESP).

Como objetivos para consecução desta pesquisa, foram consideradas as atividades de identificar, analisar, caracterizar, classificar e categorizar resumos de teses e dissertações etnográficas; em seguida, realizar a mesma tarefa sobre o conteúdo completo de dissertações e teses selecionadas e, finalmente, destacar e refletir aspectos significativos emersos, das descrições, dos relatos em pesquisas etnográficas escolares em Educação Física, em relação aos pressupostos teóricos etnográficos, curriculares críticos e pós-críticos em Educação Física Escolar.

Foram realizadas buscas por dissertações e teses, somente nos programas de pósgraduação da UNICAMP, UNESP e USP em Educação e Educação Física. Assumidas como etnográficas e escolares, treze pesquisas foram encontradas, sendo realizados exames em seus conteúdos completos em seis dos trabalhos, cinco dissertações e uma tese.

A base referencial teórica, portanto, para o desenvolvimento desta tese está circunscrita aos campos teóricos da Etnografia em Educação e Educação Física; das Teorias Críticas, de orientação marxista e neomarxistas em Educação, na concepção 
Crítico-superadora da Educação Física; nas teorias Pós-Críticas em Educação e no Currículo Cultural.

Os materiais considerados como principais fontes para o banco de dados foram resumos das dissertações e teses em Educação Física, nos programas de Pós-graduação Stricto Sensu em Educação e Educação Física inicialmente nacionais e depois somente paulistas. Realizando buscas em bancos já estabelecidos, foram inseridos termos indutores para identificar e reunir trabalhos que pudessem ser classificados como etnográficos escolares em EF.

As análises primeiramente ocorreram sobre os resumos das pesquisas autodenominadas como etnográficos em Educação Física Escolar. O método de análise de conteúdo dos resumos buscou elementos referentes aos pontos de partida, metodologia, trabalho e registro de campo, análises e resultados contidos nas dissertações e teses, que permitam estabelecer relações com os referenciais das teorias curriculares críticas, pós-críticas e etnográficas em Educação e Educação Física.

Essas apreciações procuraram, inicialmente, destacar a identificação dos trabalhos em seus títulos, autores, localização, orientador e ano de conclusão das pesquisas, procurando elementos nos resumos das teses e dissertações, sobre suas questões geradoras, problematizações e hipóteses levantadas; características do referencial teórico adotado; o tempo de realização do trabalho de campo, técnicas e instrumentos utilizados, formas de análise dos dados obtidos; construção dos relatos; apresentação dos resultados.

As análises, que tomam por base os referenciais teóricos críticos e suas influências sobre os currículos, são realizadas levando-se em conta os destaques feitos às suas principais proposições conceituais, tais como: trabalho, historicidade, movimento, dialética, materialismo-histórico, contradição, práxis, economia-política, classes, hegemonia e ideologia.

Do campo das Teorias Pós-Críticas, precisamente dos Estudos Culturais e do Multiculturalismo Crítico, as questões reflexivas são estabelecidas sobre os aspectos conceituais na teorização curricular, como diferença, identidade, cultura, gênero, etnia, orientações sexual e religiosa, fronteiras, hibridismo, bricolagem, relações de poder, práticas pedagógicas e o currículo cultural em ação.

A Etnografia busca indicar problematizações especialmente aos campos metodológicos, técnico-instrumentais e analíticos; da construção dos relatos em si e aos procedimentos pedagógicos evidenciados, indagando sobre aspectos relativos às escolhas dos pesquisadores em suas motivações, problematizações e justificativas 
iniciais; definições sobre o trabalho de campo, quantidade de tempo no processo de coleta de dados, critérios para coleta e análise dos dados; redação dos resultados, entre outras, pois, de acordo com o que afirma Geertz (1989), “[...] se você quiser compreender o que é a ciência, você deve olhar, em primeiro lugar, não para as teorias ou as suas descobertas e, certamente, não para o que seus apologistas dizem sobre ela; você deve ver o que os praticantes da ciência fazem" (p.15).

Ao focar o interesse nas pesquisas já concluídas e identificadas como etnográficas e escolares na área, procurando refletir sobre possíveis processos dialógicos em que são feitas as apropriações dos referenciais teóricos etnográficos, críticos e pós-críticos curriculares, a proposta com aproximações de caráter meta-etnográfico ${ }^{3}$ aqui sugerida compreende que, ao se percorrerem caminhos já trilhados, nas múltiplas possibilidades de práticas pedagógicas contidas nos relatos, busca-se também a orientação do caráter dialético do movimento que constitui a construção dos saberes.

[...] o conhecimento dos rumos da produção científica de uma área é fundamental para a melhoria da qualidade da pesquisa, para os avanços da ciência e, principalmente, para o diagnóstico do impacto dessa produção no âmbito social de sua criação. A busca de explicações sobre os caminhos adotados pela pesquisa permite evidenciar suas conquistas, indicar suas lacunas, ao mesmo tempo, chamar atenção para as novas alternativas de investigação (MARTINS; SILVA, 2004, p. 03).

A pesquisa apresenta então elementos sobre etnografias em Educação Física Escolar, que refletidos em relação às teorizações críticas, pós-críticas em educação e currículo, buscam também captar alternativas, possibilidades didático-metodológicas, no desenvolvimento das práticas pedagógicas escolares em Educação Física e sobre as maneiras de registrá-las etnograficamente.

$\mathrm{Na}$ primeira parte, são apresentados os resultados obtidos em relação à estruturação dos quadros teóricos em torno de duas principais áreas de abordagem: etnografia e currículos em Educação Física Escolar.

\footnotetext{
${ }^{3}$ Caldeira, (1988) sobre o termo indica que o " [...] historiador James Clifford - para quem o termo metaetnográfo foi cunhado - é seguramente uma das figuras centrais no processo de desconstrução da etnografia clássica. Em um de seus mais importantes trabalhos ele tenta mostrar os dispositivos através dos quais os antropólogos criariam em seus textos uma autoria legítima para falar sobre os outros, 'uma autoridade etnográfica"” (p.136).
} 
Nesses quadros, figuram os elementos teóricos, conceituais, instrumentais e analíticos, considerados relevantes para as finalidades das pesquisas sobre dissertações e teses etnográficas em Educação Física Escolar e foram denominados: 'Etnográfico em Educação Física'; 'Crítico-superador' e 'Cultural' em Educação Física Escolar.

Em relação às matrizes curriculares em Educação Física escolar e seus principais eixos constitutivos, foram destacados aspectos ligados mais especificamente à prática pedagógica na 'sala-quadra' de aula, pressupostos didático-metodológicos e referências conceituais fundantes de cada uma das elaborações curriculares apresentadas.

Desse modo, na matriz analítica conceitual Etnografia em Educação Física, os elementos considerados centrais foram: identificação; pontos de partida/metodologia; campo: tempo/técnicas/registros; texto: características e análises. Neste caso, optou-se em circunscrever os itens principais deste eixo, por seus respectivos marcadores técnicoinstrumentais, de modo a explicitar as estruturas norteadoras das análises dos procedimentos tanto dos trabalhos de campo, quanto dos próprios textos finais das dissertações e teses.

No que diz respeito às matrizes curriculares, no quadro Crítico-superador, os principais eixos foram estruturados na sequência: Prática social inicial; Problematização; Instrumentalização; Catarse e Prática Social Final; sendo destacados conceitos orientados pelo materialismo-histórico-dialético como: trabalho, exploração, hegemonia, ideologia; classes sociais, política, capitalismo, poder e transformação social.

Concluindo esta primeira parte, apresenta-se o quadro denominado Currículo Cultural em Educação Física Escolar, em que foram considerados como itens centrais da prática pedagógica multiculturalmente orientada: mapeamento; tematização problematização; genealogia arqueológica e registro-avaliação.

Como referencial conceitual estruturante, também são apresentados com base nas teorias pós-críticas: justiça curricular; cultura corporal da comunidade; ancoragem social dos conhecimentos; articulação com os objetivos educacionais da instituição educativa; identidade/diferença; híbrido; fronteiras; bricolagem; neoliberalismo, cultura e diferença.

Em seguida, serão detalhadas as constituições teóricas dos quadros, considerandose suas relações com o propósito central da pesquisa, qual seja, realizar um balanço das pesquisas etnográficas escolares em Educação Física, em dissertações e teses, partindo de questões que buscam abordar as apropriações feitas aos referenciais etnográficos e do mesmo modo em seguida, em relação às teorias curriculares críticas e pós-críticas em Educação Física. 
São apresentados a seguir os materiais selecionados para análise em forma de dissertações e teses em Educação Física Escolar, orientadas metodologicamente pela Etnografia, nas universidades públicas do Estado de São Paulo, nos programas de Pósgraduação em Educação e Educação Física, considerando-se sua explícita referência nos resumos e defendidos no período compreendido de 2005-2015. Durante o garimpo dos trabalhos nos bancos de dados foram empregados os descritores 'escola'; 'escolar', 'educação física escolar' nos campos de busca 'geral', 'palavras-chave' e 'resumo', assim como a grafia do termo 'etnografia', incluso duas de suas variantes: etnográfica (s), etnográficos (s).

Sobre os modos de como ocorreram as buscas nos bancos de dissertações e teses, detalhamos o exemplo do levantamento realizado sobre dissertações e teses em Educação Física desenvolvidas no Programa de Pós-graduação da Faculdade de Educação Física da Universidade Estadual de Campinas (FEF-UNICAMP), junto à Biblioteca Digital da Unicamp $^{4}$ :

Quando inserido o termo ' educação física escolar' como critério para buscas em 'todos os campos' na plataforma digital de seu Sistema de Bibliotecas da Unicamp (SBU), foram obtidos um primeiro conjunto com 90 documentos como resultado. Quando usado o mesmo termo 'educação física escolar' como critério de busca, porém para o campo específico, 'palavras-chave', foram obtidos 56 documentos.

Pela leitura desses 56 resumos puderam ser considerados, como que relacionadas aos temas específicos escolares em Educação Física, 33 pesquisas. Deste segundo subconjunto, foram excluídos os trabalhos com temas relacionados à formação inicial e continuada de professores, biografias, história e política da Educação Física. Ainda foram excluídos aqueles que, mesmo com temas como jogos, esportes, aptidão física e saúde, não se referiam diretamente ao exercício de práticas pedagógicas em aulas de Educação Física nas escolas, em forma de relatos ou análises curriculares. ${ }^{5}$

\footnotetext{
4 Os procedimentos aqui elencados junto ao Programa de Pós-Graduação em Educação Física da UNICAMP foram os mesmos utilizados nas bibliotecas virtuais dos programas de Pós-graduação em Educação e Educação Física consultados da USP e da UNESP.

5 Também foram excluídas as pesquisas realizadas em período não correspondente ao determinado para esse levantamento, em que foram considerados os últimos dez anos, a partir de 2005.
} 
Dentro desse segundo subconjunto, puderam ser encontradas pesquisas que na indicação de suas metodologias estavam denominadas como: pesquisa-ação (3); análise do discurso (1); pesquisa exploratória descritiva (1); estudo de caso (2); grupo focal (1); análise do conteúdo (1). Por não apresentarem explicitação alguma quanto à metodologia empregada ou apenas autorreferidas somente como 'pesquisas qualitativas', catorze pesquisas foram consideradas como "sem metodologia indicada" e, portanto, também não incluídas.

Foram assim auferidas 13 pesquisas que puderam ser identificadas em suas metodologias como que relacionadas à etnografia, assim nominadas: 'etnografia'; 'pesquisa etnográfica'; ‘tipo etnográfica'; 'método etnográfico'; 'perspectiva etnográfica'; 'estudo etnográfico'; 'estudo do caso etnográfico'; 'cunho etnográfico'; sendo 4 teses e 9 dissertações.

A identificação por meio de quadros se dá pela instituição universitária e pelo programa de pós-graduação em que as pesquisas foram realizadas, com o título e ano da defesa; sua forma, se dissertação ou tese; excertos da metodologia e palavras-chave. A banca examinadora também é elencada. Cada pesquisa é acompanhada de uma análise em que se são destacados os objetivos e pontos de partida, aspectos metodológicos e curriculares apresentados nos resumos. 


\subsection{DISSERTAÇÕES ESCOLARES EM EDUCAÇÃO FÍSICA}

01. O impacto dos PCN na prática dos professores de educação física. 2007. FEUSP 6 .

\begin{tabular}{|l|l|l|}
\hline \multicolumn{1}{|c|}{ Autor } & \multicolumn{1}{|c|}{ Metodologia } & \multicolumn{1}{|c|}{ Palavras-chave } \\
\hline & $\begin{array}{l}\text { Educação Física } \\
{[\ldots] \text { foram eleitas quatro categorias que }} \\
\text { fundamentaram uma investigação } \\
\text { etnográfica com professores atuantes no } \\
\text { Gramorelli, } \\
\text { Lilian Cristina } \\
7\end{array}$ & $\begin{array}{l}\text { Earâmetros } \\
\text { Curriculares } \\
\text { Nacionais }\end{array}$ \\
& & Prática Educativa \\
\hline
\end{tabular}

Em relação aos pontos de partida, a pesquisadora ao considerar as reformulações ocorridas, no Brasil, do currículo nacional, nos finais da década de 90, procura apresentar como estão expressas as especificidades do componente curricular da disciplina de Educação Física no documento, assim como, as apropriações feitas pelos professores na realização de suas práticas educativas.

Quanto à metodologia expressa que, aliada à revisão bibliográfica sobre temas ligados às práticas dos professores de Educação Física Escolar, (pós-LDB ${ }^{8}$, 9394/96) e uma análise documental específica dos PCN, Parâmetros Curriculares Nacionais, $\left(3^{\circ} \mathrm{e}\right.$ $4^{\mathrm{o}}$ ciclos Educação Física), realizou também uma investigação etnográfica.

No que diz respeito aos aspectos curriculares, as referências se apoiam nos PCN, objeto documental da pesquisa, em seus conteúdos e apropriações, permitindo a identificação de aproximações dos professores em relação às proposições apresentadas, caracterizando assim o que a autora denomina como uma 'influência desencadeada'.

\footnotetext{
${ }^{6}$ Faculdade de Educação da Universidade São Paulo.

7 Banca examinadora: Neira, Marcos Garcia (Presidente); Darido, Suraya Cristina; Fusari, José Cerchi. Área temática: Didática, Teorias de Ensino e Práticas Escolares.

${ }^{8}$ Lei de diretrizes e bases da educação nacional.
} 
02. Cultura corporal juvenil da periferia paulistana: subsídios para construção de um currículo de educação física. 2007. FEUSP.

\begin{tabular}{|l|l|l|}
\hline \multicolumn{1}{|c|}{ Autor } & \multicolumn{1}{|c|}{ Metodologia } & Palavras-chave \\
\hline & $\begin{array}{l}\text { Para tanto, foi desenvolvida uma pesquisa de } \\
\text { cunho qualitativo de tipo etnográfico que }\end{array}$ & Cultura corporal \\
$\begin{array}{l}\text { Chaim } \\
\text { Junior, } \\
\text { Cyro Irany } \\
9\end{array}$ & $\begin{array}{l}\text { questionamentos a grupo focal, o repertório } \\
\text { cultural corporal juvenil pertencente a um } \\
\text { grupo socialmente desprivilegiado tomando- } \\
\text { se como referência o critério econômico. }\end{array}$ & Currículo \\
\hline
\end{tabular}

Como ponto de partida, esta pesquisa enfoca interesses sobre jovens, o reconhecimento dos saberes que seus grupos sociais apresentam na escola e como 'patrimônio cultural' dos mesmos são negligenciados nos currículos.

Apoiado nos referenciais da teorização cultural, declara como opção metodológica a pesquisa de cunho qualitativo do tipo etnográfico, com formação de grupo focal.

Relacionados os dados obtidos em campo sobre o repertório cultural corporal juvenil, elabora uma proposta curricular de intervenção na perspectiva sociocultural.

\footnotetext{
${ }^{9}$ Banca examinadora: Neira, Marcos Garcia (Presidente); Gallardo, Jorge Sérgio Perez; Souza Neto, Samuel de. Área temática: Didática, Teorias de Ensino e Práticas Escolares.
} 
3. A Educação Física articulada ao currículo transdisciplinar. 2012. EEFE - USP. ${ }^{10}$

\begin{tabular}{|c|c|c|}
\hline Autor & Metodologia & Palavras-chave \\
\hline $\begin{array}{l}\text { Caselli, } \\
\text { Alvaro } \\
\text { José }^{11}\end{array}$ & $\begin{array}{l}\text { A escolha metodológica pelo estudo de caso } \\
\text { etnográfico reuniu no estudo I professores } \\
\text { de classe e professores especialistas de } \\
\text { diversas áreas e, no estudo II professores de } \\
\text { Educação Física. A investigação pautou-se } \\
\text { na descrição densa e análise de documentos, } \\
\text { das entrevistas semiestruturadas reflexivas } \\
\text { e da observação participante durante } \\
\text { reuniões com professores. }\end{array}$ & $\begin{array}{l}\text { Currículo de ensino } \\
\text { fundamental } \\
\text { Educação Física - } \\
\text { Estudo e ensino } \\
\text { Educação infantil } \\
\text { Ensino fundamental } \\
\text { Transdisciplinaridade }\end{array}$ \\
\hline
\end{tabular}

Problematizando a estrutura curricular da educação infantil e do ensino fundamental, com organizações disciplinares apresentadas de forma isolada, linear e justapostas à pesquisa, enfatiza estudos sobre um currículo baseado no PYP (Primary Years Programme), modelo de currículo integrado organizado por temas transdisciplinares elaborado, implantado e supervisionado pelo IB - International Baccalaureate.

O procedimento metodológico declarado é o 'estudo do caso etnográfico', com descrição densa, análise documental, entrevistas semiestruturadas e observação participante, com professores de classe, especialistas de diferentes áreas e de educação física.

Descreve, analisa as características e pressupostos do programa PYP e a articulação da disciplina específica de educação física a um currículo transdisciplinar.

\footnotetext{
${ }^{10}$ Escola de Educação Física e Esporte - USP.

${ }^{11}$ Banca examinadora: Ferraz, Osvaldo Luiz (Presidente); Correia, Walter Roberto; Neira, Marcos Garcia. Área de concentração: Pedagogia do Movimento Humano.
} 
4. Educação física, escola e cultura: o enredo das diferenças. 2006. FEF UNICAMP.

\begin{tabular}{|l|l|l|}
\hline \multicolumn{1}{|c|}{ Autor } & \multicolumn{1}{|c|}{ Metodologia } & \multicolumn{1}{|c|}{ Palavras-chave } \\
\hline Oliveira, & $\begin{array}{l}|c| \\
\text { O trabalho está delineado como uma } \\
\text { Rogerio } \\
\text { etnografia, no sentido de uma "descrição } \\
\text { densa". }\end{array}$ & $\begin{array}{l}\text { Educação Física } \\
\text { Escolar }\end{array}$ \\
& $\begin{array}{l}\text { Cultura } \\
\text { Diversidade cultural }\end{array}$ \\
\hline
\end{tabular}

Neste trabalho, o tema central diz respeito à representação realizada pelos alunos nas aulas de Educação Física em relação à significação das diferenças.

Afirma a pesquisa delineada como uma etnografia, no sentido de uma 'descrição densa', Geertz (1989), em uma turma de oitava série do ensino fundamental de uma escola pública do município de Campinas, durante um bimestre letivo.

Em termos curriculares, destaca os subsídios dados pela perspectiva intercultural de Educação e Educação Física, no qual as diferenças devem ser consideradas sob a ótica da alteridade.

\footnotetext{
12 Banca: Jocimar Daolio [Orientador]; Neusa Maria Mendes de Gusmão; Eliana Ayoub. Área de concentração: Educação Física e Sociedade.
} 
05. Marcas da religião evangélica na educação do corpo feminino: implicações para a educação física escolar. 2008. FEF - UNICAMP.

\begin{tabular}{|l|l|l|}
\hline \multicolumn{1}{|c|}{ Autor } & \multicolumn{1}{|c|}{ Metodologia } & \multicolumn{1}{|c|}{ Palavras-chave } \\
\hline & & Educação \\
$\begin{array}{l}\text { Rigoni, } \\
\text { Ana } \\
\text { Carolina } \\
\text { Capellini }\end{array}{ }^{33}$ & $\begin{array}{l}\text { Sendo assim, este estudo se constitui como } \\
\text { uma etnografia realizada em uma Igreja } \\
\text { Evangélica Assembleia de Deus, na cidade } \\
\text { de Campinas/SP. }\end{array}$ & Religião \\
& \multicolumn{1}{|c|}{$\begin{array}{l}\text { Corpo } \\
\text { Educação Física }\end{array}$} \\
\hline
\end{tabular}

Esta investigação tem como tema a educação dos corpos femininos a partir de uma determinada religião, a Igreja Evangélica Assembleia de Deus em suas implicações para as aulas de Educação Física Escolar.

Valendo-se do referencial teórico das Ciências Humanas, com autores da Educação Física; da Sociologia, da Antropologia; destaca a importância de Clifford Geertz, assim como de outros autores que tratam especificamente da vertente religiosa evangélica. Denominada como uma 'pesquisa etnográfica', foi realizada na Igreja Evangélica Assembleia de Deus, na cidade de Campinas/SP, com um ano e nove meses de duração, sendo utilizada observação participante e entrevistas semiestruturadas, com o pastor, membros da comunidade e especialmente com as meninas selecionadas para a pesquisa.

Afirmando que a disciplina de Educação Física, nos termos curriculares assumidos, possui como conteúdo principal elementos da cultura corporal de movimento, relaciona a educação dos gestos dos alunos em suas aulas e a influência sofrida pela gestualidade trazida de fora da escola, no caso a religiosa.

\footnotetext{
${ }^{13}$ Banca: Elaine Prodocimo [Orientador]; Eliane Moura da Silva; Jocimar Daolio. Área de concentração: Educação Física e Sociedade.
} 
06. Os saberes cotidianos de alunos nas aulas de educação física: implicações para a prática pedagógica. 2008. FEF- UNICAMP.

\begin{tabular}{|l|l|l|}
\hline \multicolumn{1}{|c|}{ Autor } & \multicolumn{1}{|c|}{ Metodologia } & \multicolumn{1}{|c|}{ Palavras-chave } \\
\hline $\begin{array}{l}\text { Rodrigues } \\
\text { Junior, } \\
\text { Jose } \\
\text { Carlos }\end{array}$ & $\begin{array}{l}\text { Optou-se por um estudo de cunho qualitativo } \\
\text { de perspectiva etnográfica, ancorado nos } \\
\text { pressupostos da 'descrição densa. }\end{array}$ & $\begin{array}{l}\text { Educação física } \\
\text { escolar } \\
\text { Prática pedagógica } \\
\text { Senso comum }\end{array}$ \\
\hline
\end{tabular}

Esta pesquisa aborda as compreensões que uma professora de Educação Física do ensino fundamental possui sobre os saberes cotidianos da cultura corporal de seus alunos e suas implicações para elaboração das práticas pedagógicas da docente.

A opção metodológica é identificada como qualitativa de 'cunho etnográfica', com ênfase nos pressupostos de uma 'descrição densa', com observação de aulas e realização de duas entrevistas semiestruturadas.

Afirma que os dados revelam nenhum acesso aos saberes dos alunos, em que se acrescentam aspectos pedagógicos e curriculares negativos como ausência de planejamento, falta de direcionamento metodológico e dificuldades de compreensão da especificidade da educação física na escola.

\footnotetext{
14 Jocimar Daolio [Orientador]; Neusa Maria Mendes de Gusmão; Helena Altmann. Área de concentração: Educação Física e Sociedade.
} 
07. Educação Física escolar e relações de gênero: risco, confiança, organização e sociabilidades em diferentes conteúdos. 2012. FEF - UNICAMP.

\begin{tabular}{|c|c|c|}
\hline Autor & Metodologia & Palavras-chave \\
\hline $\begin{array}{l}\text { Uchoga, } \\
\text { Liane } \\
\text { Aparecida } \\
\text { Roveran }{ }^{15}\end{array}$ & $\begin{array}{l}\text { Por meio de uma pesquisa do tipo } \\
\text { etnográfica, em três (3) séries de duas (2) } \\
\text { escolas pertencentes à Região } \\
\text { Metropolitana de Campinas, foram } \\
\text { observadas aulas de educação física que } \\
\text { apresentavam uma variação de conteúdos } \\
\text { ao longo dos bimestres e realizadas } \\
\text { entrevistas semiestruturadas, com } \\
\text { professores/as e alunos/as das turmas. }\end{array}$ & $\begin{array}{l}\text { Gênero } \\
\text { Educação física } \\
\text { Escola } \\
\text { Relações } \\
\text { interpessoais }\end{array}$ \\
\hline
\end{tabular}

Com tema sobre as relações de gênero nos diferentes conteúdos da educação física escolar, a pesquisa é denominada como do 'tipo etnográfica', realizada em três (3) séries de duas (2) escolas da Região Metropolitana de Campinas, com observações de aulas e entrevistas semiestruturadas com professores (as) e alunos (as).

Ao abordar os conteúdos de ginástica e esportes e os discursos generificados sobre ambos, destaca que é a noção compartilhada de que meninos sejam mais capazes em função de suas maiores habilidades é a que prevalece, independente do conteúdo. Quanto às meninas, registra-se sua maior capacidade organizativa.

Destaca a importância de se compreender as influências das construções de gênero para as aulas de Educação Física e como seus conteúdos podem colaborar sobre as percepções das relações de gênero existentes na própria intuição escolar.

\footnotetext{
${ }^{15}$ Helena Altmann [Orientador]; Claudia Pereira Viana; Jocimar Daolio. Área de concentração: Educação Física e Sociedade.
} 


\section{A prática pedagógica de Educação Física a partir do currículo de São}

Paulo. 2014. FEF - UNICAMP.

\begin{tabular}{|c|c|c|}
\hline Autor & Metodologia & Palavras-chave \\
\hline $\begin{array}{l}\text { Rocha, } \\
\text { Robinson } \\
\text { Luiz } \\
\text { Franco } \\
\mathrm{da}^{16}\end{array}$ & $\begin{array}{l}\text { Para isso, adotou-se a realização de um } \\
\text { estudo de caso etnográfico, referenciado pela } \\
\text { definição de "descrição densa" proposta por } \\
\text { Clifford Geertz. }\end{array}$ & $\begin{array}{l}\text { Educação Física } \\
\text { escolar } \\
\text { Prática } \\
\text { pedagógica } \\
\text { Currículos } \\
\text { Saberes docentes }\end{array}$ \\
\hline
\end{tabular}

Esta pesquisa aborda questões sobre o impacto da implementação da Proposta Curricular de Educação Física do Estado de São Paulo na construção das práticas pedagógicas pelos professores da disciplina.

Com metodologia denominada como um 'estudo do caso etnográfico', com 'descrição densa', Geertz (1998), em uma escola do município de Rio Claro, em 16 semanas, com 25 dias de observações de aulas e duas entrevistas semiestruturadas com a professora.

Destaca, no desenvolvimento das práticas pedagógicas pela professora, a 'aplicação' das orientações sugeridas no 'Cadernos do Professor', em processo de interação com seus próprios saberes experienciais, com adoções, adaptações, adições e exclusões de propostas contidas nos documentos oficiais. Processo esse considerado como uma 'retomada crítica' dos saberes envolvidos e denominado em sua execução didática como 'alternativa curricular'.

\footnotetext{
${ }^{16}$ Jocimar Daolio [Orientador]; Eliana Ayoub; Elaine Prosdócimo. Área de concentração: Educação Física e Sociedade.
} 
9. Diferenças, inclusão e educação física: significados produzidos pelas crianças. 2015. FEF - UNICAMP.

\begin{tabular}{|c|c|c|}
\hline Autor & Metodologia & Palavras-chave \\
\hline $\begin{array}{l}\text { Ferreira, } \\
\text { Flávia } \\
\text { Martinelli }^{17}\end{array}$ & $\begin{array}{l}\text { A pesquisa de cunho etnográfico foi } \\
\text { realizada ao longo de dois bimestres letivos } \\
\text { com uma turma formada por vinte e seis } \\
\text { alunos (oito meninos e dezoito meninas). }\end{array}$ & $\begin{array}{l}\text { Educação física } \\
\text { escolar } \\
\text { Diferenças } \\
\text { Inclusão } \\
\text { Cultura infantil }\end{array}$ \\
\hline
\end{tabular}

Esta dissertação apresenta como objetivo compreender a produção das diferenças e seus significados nas aulas de Educação Física a partir das dinâmicas culturais infantis.

De 'cunho etnográfico', com observações e elaboração de uma 'descrição densa', a pesquisa foi realizada com crianças do quarto ano do ensino fundamental da Prefeitura de Jundiaí - SP, em dois bimestres letivos, com uma turma formada por vinte e seis alunos (oito meninos e dezoito meninas). Além das aulas de educação física, outros momentos também foram considerados como os de entrada e saída da escola, os tempos de recreação e outros dias letivos.

Em termos curriculares, considerando as diferenciações como produções sociais, argumenta a favor de estratégias pedagógicas que abordem as diferenças, discutindo sua produção e mecanismo de criação e fixação.

\footnotetext{
${ }^{17}$ Jocimar Daolio [Orientador]; Mauro Betti; Edivaldo Góis Junior. Área de concentração: Educação Física e Sociedade.
} 


\subsection{TESES ESCOLARES EM EDUCAÇÃO FÍSICA}

10. Educação física no Ensino Médio: representações dos alunos. 2008. FEF - UNICAMP.

\begin{tabular}{|c|c|c|}
\hline Autor & Metodologia & Palavras-chave \\
\hline $\begin{array}{l}\text { Souza, } \\
\text { Adalberto } \\
\text { dos Santos }^{18}\end{array}$ & $\begin{array}{l}\text { [...] optei pela realização de uma pesquisa } \\
\text { etnográfica, uma vez que ela pode permitir } \\
\text { um mergulho mais denso no universo } \\
\text { escolar, possibilitando, desta forma, uma } \\
\text { análise também densa sobre o assunto. }\end{array}$ & $\begin{array}{l}\text { Educação Física } \\
\text { Educação Física } \\
\text { escolar } \\
\text { Cultura } \\
\text { Escola } \\
\text { Representação } \\
\text { social }\end{array}$ \\
\hline
\end{tabular}

Esta pesquisa teve como tema central a identificação das representações que alunos do ensino médio possuem em relação às aulas de Educação Física.

A opção metodológica foi 'etnográfica', que permitiria uma 'análise densa' sobre o universo escolar, com ênfases nas formas de expressões de interesses dos jovens nas aulas de Educação Física.

Sobre o currículo, delimitado no Ensino Médio, destaca o papel que a Educação Física teria nesta etapa, a visão da disciplina pelos alunos e as perspectivas para suas representações, considerando-se as influências externas e internas que envolvem os contextos cultural e escolar.

\footnotetext{
${ }^{18}$ Jocimar Daolio [Orientador]; Ana Lúcia Guedes Pinto; Mauro Betti; Helena Altmann; Eliana Ayoub. Área de concentração: Educação Física e Sociedade.
} 
11. Na "periferia" da quadra: educação física, cultura e sociabilidade na escola. 2010. FEF - UNICAMP.

\begin{tabular}{|l|c|l|}
\hline \multicolumn{1}{|c|}{ Autor } & Metodologia & \multicolumn{1}{c|}{ Palavras-chave } \\
\hline $\begin{array}{l}\text { Oliveira, } \\
\text { Rogério } \\
\text { Cruz de }\end{array}$ & $\begin{array}{c}\text { O método de pesquisa centrou-se na } \\
\text { etnografia, sendo o trabalho de campo } \\
\text { desenvolvido por 6 (seis) meses com uma } \\
\text { turma de } 7^{0} \text { ano de uma escola pública em } \\
\text { suas aulas de Educação Física. }\end{array}$ & Euca \\
& $\begin{array}{c}\text { Cultura } \\
\text { Diferença }\end{array}$ & Sociabilidade \\
\hline
\end{tabular}

Esta pesquisa apresenta como objetivo a compreensão das dinâmicas culturais, de participação e apropriação, que envolvem os alunos que se situam à margem nas aulas de educação física - na 'periferia' da quadra- e os fatores que permitem esta condição.

O método apresentado é o da 'etnografia', com trabalho de campo de 6 (seis) meses com uma turma de $7^{\circ}$ ano de uma escola pública em suas aulas de Educação Física. Foram utilizadas entrevistas semiestruturadas, análise de documentos e observação das aulas de Educação Física.

Em termos curriculares, no que diz respeito ao ensino-aprendizagem, apresenta práticas esportivas não - diretivas e o entendimento das aulas de Educação Física como tempos e espaços menos rígidos dentro da escola. Afirma estarem ausentes as apropriações em relação aos conhecimentos da cultura corporal. Os alunos realizam críticas à escola, à disciplina e ao professor, mas também proposições de alternativas.

\footnotetext{
${ }^{19}$ Jocimar Daolio [Orientador]; Eliana Ayoub; Helena Altmann; Mauro Betti; Tarcísio Mauro Vaga. Área de concentração: Educação Física e Sociedade
} 
12. Corpos na escola: (des) compassos entre a educação física e a religião. 2013. FEF - UNICAMP.

\begin{tabular}{|c|c|c|}
\hline Autor & Metodologia & Palavras-chave \\
\hline $\begin{array}{l}\text { Rigoni, Ana } \\
\text { Carolina } \\
\text { Capellini }^{20}\end{array}$ & $\begin{array}{l}\text { O método utilizado foi o etnográfico, } \\
\text { tendo como principal referência o } \\
\text { conceito de "descrição densa" do } \\
\text { antropólogo Clifford Geertz. }\end{array}$ & $\begin{array}{l}\text { Educação física } \\
\text { escolar } \\
\text { Corpo } \\
\text { Religião }\end{array}$ \\
\hline
\end{tabular}

Neste trabalho, o tema é sobre a educação física na escola em relação à educação religiosa, evangélica, fora da escola. As influências, tensões e 'acomodamentos' que ocorrem nas aulas de Educação Física. Apresenta um levantamento sobre o "corpo" e a religião na análise antropológica.

O método é denominado como ‘etnográfico', por ser orientado por uma 'descrição densa', Geertz (1998), com observações, entrevistas e conversas informais registradas. Teve como participantes cinco meninas de duas instituições diferentes, Congregação Cristã no Brasil (CC) e a igreja evangélica Assembleia de Deus (AD), cursando os anos finais do Ensino Médio, que foram acompanhadas nas aulas de Educação Física, durante o ano de 2011.

Considerando os problemas referentes aos professores e à escola, relaciona os dados à especificidade da instituição e da disciplina deEducação Física.

\footnotetext{
${ }^{20}$ Jocimar Daolio [Orientador]; Tarcísio Mauro Vago; Alex Branco Fraga; Ronaldo Rômulo Machado de Almeida; Helena Altmann. Área de concentração: Educação Física e Sociedade.
} 
13. Educação física escolar e os saberes na ação docente. 2014. FEF UNICAMP.

\begin{tabular}{|c|c|c|}
\hline Autor & Metodologia & Palavras-chave \\
\hline $\begin{array}{l}\text { Celante, } \\
\text { Adriano } \\
\text { Rogério }^{21}\end{array}$ & $\begin{array}{l}{[\ldots] \text { se caracteriza como um "estudo }} \\
\text { etnográfico", que se dedicou a descrever os } \\
\text { "saberes na ação" de três professores de } \\
\text { educação física. }\end{array}$ & $\begin{array}{l}\text { Saberes docentes } \\
\text { Professores } \\
\text { Formação } \\
\text { Educação física } \\
\text { escolar }\end{array}$ \\
\hline
\end{tabular}

A pesquisa teve como questão central compreender como os professores de Educação Física atribuem sentidos às práticas pedagógicas em suas aulas, considerando sua formação acadêmica e outras formas de saber de acordo com suas trajetórias de vida.

Caracteriza o trabalho como um 'estudo etnográfico', uma "descrição densa", interpretativa, Geertz (1989), no qual se dá um processo interativo em campo, com observação de aulas e diálogos com os docentes, sendo priorizado o ponto de vista do "outro". Realizado com três professores de educação física que atuam nas séries iniciais do ensino fundamental, em escolas da rede municipal de ensino da cidade de Jundiaí-SP.

A abordagem curricular compreende uma investigação dos 'saberes na ação', no cotidiano escolar, que constituem parte da 'cultura profissional' dos docentes.

Dos 13 trabalhos obtidos junto aos bancos de dissertações e teses em Educação e Educação Física das três universidades paulistas públicas (USP; UNICAMP e UNESP), quatro são teses e nove são dissertações. As teses estão todas na UNICAMP, na Faculdade de Educação Física, no Programa de Pós-graduação em Educação Física, na área de concentração Educação Física e Sociedade, na linha de pesquisa "Corpo, Educação e Escola", e sob supervisão de um único orientador, o Professor Jocimar Daolio, nos anos de 2008 (10), 2010 (11), 2013 (12) e 2014 (13). ${ }^{22}$

\footnotetext{
${ }^{21}$ Jocimar Daolio [Orientador]; Ana Lúcia Guedes Pinto; Odilon José Roble; Osvaldo Luiz Ferraz; Walter Roberto Correia. Área de concentração: Educação Física e Sociedade.

${ }^{22}$ Ao lado do ano de defesa da pesquisa se encontra o número do trabalho em relação à sequência de quadros listados.
} 
As dissertações estão na USP, no Programa de Pós-graduação da Faculdade de Educação (FEUSP), na área temática: Didática, Teorias de Ensino e Práticas Escolares. 2007 (01) e (02), com orientação do Professor Marcos Garcia Neira e no Programa da Pós-graduação da Escola de Educação Física e Esportes, área de concentração, Pedagogia do Movimento Humano, em 2012 (03), orientada pelo Professor Osvaldo Luiz. As outras seis dissertações todas foram elaboradas na Faculdade de Educação Física da UNICAMP, 2006 (04); 2008 (05), (06); 2012 (07); 2014 (08); 2015 (09). Jocimar Daolio orientou as dissertações (04); (06), (09), (08); a Professora Elaine Prodócimo orientou a dissertação (05) e a Professora Helena Altmann a dissertação (07). ${ }^{23}$

A concentração de trabalhos por ano de defesa foram, em 2007, duas dissertações; 2008, uma tese e duas dissertações; 2010, uma tese; 2012, duas dissertações; 2013, uma tese; 2014, uma tese e uma dissertação e 2015, uma dissertação. Nos anos 2009 e 2011 não foram encontrados trabalhos. Também não foram encontradas dissertações ou teses de caráter etnográfico em Educação Física nos Programas de Pós-graduação em Educação e o de Ciências da Motricidade Humana da UNESP, no período delimitado, de 20052015 .

Em torno da terminologia etnográfica, no que se refere às metodologias empregadas nos trabalhos, encontram-se: 'pesquisa etnográfica', (1), (5) e (10); do tipo etnográfico (2) e (7); estudo do caso etnográfico', (03) e (08); etnografia, (4) e (11); qualitativa de cunho etnográfica, (06) e (09) e estudo etnográfico (12) e (13).

Em relação aos temas, quatro pesquisas se remetem a aspectos curriculares e práticas escolares em aulas de Educação Física, como as pesquisas (01) sobre diretrizes curriculares e práticas pedagógicas docentes PCN; (02) sobre cultura corporal juvenil e currículo sociocultural em Educação Física; (3) ensino fundamental e transdisciplinariedade; (08) diretrizes curriculares e práticas pedagógicas docentes a partir do Currículo Oficial de São Paulo. Sobre diferença e diversidade cultural, três trabalhos, (09) e (11) e (04). Sobre os saberes nas aulas de Educação Física, formação acadêmica, profissional, cotidiana e do senso comum três pesquisas, (06), (07), (10). Sobre religião e práticas educativas escolares em Educação Física, duas pesquisas, (05) e (12) e sobre questões de gênero nas aulas de Educação Física, uma pesquisa (07).

\footnotetext{
23 Destaque-se que Jocimar Daolio é orientador de mestrado e doutorado de dois dos autores respectivamente, Rogério Cruz de Oliveira (04) e (11) e Ana Carolina Capellini Rigoni, (05); (12).
} 
São identificados como principais sujeitos para as pesquisas professores da Educação Física das redes públicas e privadas de ensinos fundamental I e II, médio e Educação Infantil: (1), (3), (7), (8) e (13); os alunos e alunas do ensino médio, (02), (10) e (12); alunos e alunas do ensino fundamental I, (06) e (09); alunos e alunas do ensino fundamental: II (04), (11). Outros: especialistas de diversas áreas (03); alunas evangélicas (05) e (12); pastor (05).

Quanto aos locais de realização das pesquisas são apresentadas: uma escola pública do município de Campinas; uma igreja evangélica, na cidade de Campinas/SP; escolas da Região Metropolitana de Campinas; uma escola do município de Rio Claro e uma escola do ensino fundamental da Prefeitura de Jundiaí (SP). Nove pesquisas não indicam com precisão os locais de coleta de dados de campo.

Os períodos indicados na realização dos trabalhos de campo variam entre um ou dois bimestres (4) e (9); dezesseis semanas, sendo 25 dias de observações, (08); seis meses (11) e um ano e nove meses (5); tempos de recreação e outros dias letivos são citados, mas não especificados em horas ou quantos dias (09), sete trabalhos não informam a duração de tempo do trabalho de campo ou observações, (01), (02), (03), (06), (07), (10), (12), (13).

Em relação às técnicas, foram mencionadas a de 'Grupo Focal', duas vezes, nas pesquisas (01) e (02); Entrevistas semiestruturadas, (03), (05), (07), (08), (11), cinco vezes; análise documental, três vezes, (01), (03), (11), Observações participantes, duas (03), (05). Observações de aulas (06), (07) e (11); apenas como 'Observações', 'Entrevistas' e 'Conversas informais' (09), (12). A pesquisa (13) afirma estar compreendida como "processo interativo em campo, com observação de aulas e diálogos com os docentes, sendo priorizado o ponto de vista do "outro". As pesquisas (04) e (10) não permitiram inferir dados sobre o uso de técnicas e instrumentos pelos registros em seu resumo.

Quanto às palavras-chave mais frequentes são os termos "Educação Física Escolar", oito vezes; em seguida termos relacionados à Cultura, seis vezes, como exemplos, 'cultura corporal', 'cultura juvenil', 'diversidade cultural' e 'cultura infantil'; 'educação física”, cinco vezes. Palavras-chave relacionadas a Currículo, quatro vezes, com 'parâmetros curriculares nacionais', 'currículo de ensino fundamental' e ‘currículos'; em relação aos processos docentes em Educação Física Escolar, três vezes com 'práticas pedagógicas', 'práticas educativas' e 'saberes docentes'; o termo 'escola' também aparece três vezes; 'diferença', 'corpo' e 'religião', duas vezes; 'estudo e 
ensino', 'educação infantil', 'educação', 'corpo', 'senso comum', 'gênero', 'relações interpessoais', 'inclusão', 'representação social', 'sociabilidade', 'professores', ‘formação' são relacionadas somente uma vez.

As referências curriculares identificadas foram listadas e numeradas na ordem em que foram apresentadas nos quadros das pesquisas:

1. No que diz respeito aos aspectos curriculares, as referências se apoiam nos PCN, objeto documental da pesquisa, em seus conteúdos e apropriações, permitindo a identificação de aproximações dos professores em relação às proposições apresentadas, caracterizando assim o que a autora denomina como uma 'influência desencadeada'.

2. Relacionando os dados obtidos em campo sobre o repertório cultural corporal juvenil elabora uma proposta curricular de intervenção na perspectiva sociocultural.

3. Currículo baseado no PYP (Primary Years Programme), modelo de currículo integrado, organizado por temas transdisciplinares elaborado, implantado e supervisionado pelo IB - International Baccalaureate.

4. Perspectiva intercultural de Educação e Educação Física, no qual as diferenças devem ser consideradas sob a ótica da alteridade.

5. A Educação Física possui como conteúdo principal elementos da cultura corporal de movimento,

6. Ausência de planejamento, falta de direcionamento metodológico e dificuldades de compreensão da especificidade da educação física na escola.

7. Construções de gênero para as aulas

8. Implementação da proposta curricular de educação física do Estado de São Paulo.

9. Estratégias pedagógicas que abordem as diferenças, discutindo sua produção e mecanismo de criação e fixação.

10. Delimitado no Ensino Médio, destaca o papel que a Educação Física teria nesta etapa,

11. No que diz respeito ao ensino-aprendizagem, apresenta práticas esportivas não diretivas e o entendimento das aulas de Educação Física como tempos e espaços menos rígidos dentro da escola.

12. Sem referências curriculares identificadas. 
13. Formação acadêmica e outras formas de saber de acordo com suas trajetórias de vida. Saberes na ação, no cotidiano escolar, que constituem parte da cultura profissional dos docentes.

Em seguida serão apresentadas análises de caráter descritivo dos conteúdos completos de seis, das 13 pesquisas listadas acima, com ênfases aos seus aspectos metodológicos e curriculares. Sendo destacadas as características gerais referentes às principais questões de pesquisa, os modos de como foram compreendidos os trabalhos de campo, quanto às observações; análises documentais e entrevistas semiestruturadas; articulações com o referencial teórico e documental curriculares.

\subsection{DESCRIÇÕES DE DISSERTAÇÕES E TESE}

A sequência de trabalhos analisados obteve a ordem apresentada a seguir, em que foi levada em consideração a variação de pelo menos um trabalho por orientador e a cronologia, a exceção do professor Jocimar Daolio com uma dissertação e uma tese, o que resultou em um total de cinco dissertações e uma tese.

1. O impacto dos PCN na prática dos professores de educação física. 2007. FEUSP, de Gramorelli, Lilian Cristina. Neira, Marcos Garcia (Orientador); Darido, Suraya Cristina; Fusari, José Cerchi, (banca); Área temática: Didática, Teorias de Ensino e Práticas Escolares.

2. A prática pedagógica de educação física a partir do currículo de São Paulo. 2014. FEF - UNICAMP, de Rocha, Robinson Luiz Franco da. Jocimar Daolio (Orientador); Eliana Ayoub; Elaine Prodócimo, (banca). Área de concentração: Educação Física e Sociedade.

3. A educação física articulada ao currículo transdisciplinar, de 2012 na EEFE - USP, de Álvaro José Caselli; Ferraz, Osvaldo Luiz (Orientador); Correia, Walter Roberto; Neira, Marcos Garcia, (banca); na área de concentração: Pedagogia do Movimento Humano.

4. Marcas da religião evangélica na educação do corpo feminino: implicações para a educação física escolar, 2008, FEF - UNICAMP. De Ana Carolina Capellini Rigoni. Elaine Prodócimo (Orientador); Eliane Moura da 
Silva; Jocimar Daolio (banca). Área de concentração: Educação Física e Sociedade.

5. Educação física escolar e relações de gênero: risco, confiança, organização e sociabilidades em diferentes conteúdos. 2012. FEF - UNICAMP; Liane Aparecida Roveran Uchoga; Helena Altmann (Orientadora); Claudia Pereira Viana; Jocimar Daolio (banca). Área de concentração: Educação Física e Sociedade.

6. Na "periferia" da quadra: educação física, cultura e sociabilidade na escola. 2010. FEF - UNICAMP. Rogério Cruz de Oliveira. Jocimar Daolio [Orientador]; Eliana Ayoub; Helena Altmann; Mauro Betti; Tarcísio Mauro Vago. Área de concentração: Educação Física e Sociedade.

\section{A) DISSERTAÇÕES}

01. GRAMORELLI, Lilian Cristina. O impacto dos PCN na prática dos professores de educação física. 2007.

A pesquisa teve como tema principal "identificar as possíveis influências das inovações trazidas pelos Parâmetros Curriculares Nacionais na prática pedagógica dos professores de Educação Física” (p.56).

O procedimento adotado é denominado como uma pesquisa qualitativa do tipo etnográfica, em que se considera como pontos de partida, a compreensão sobre os modos que os professores de Educação Física ressignificam as proposições apresentadas nos PCN em suas aulas e as apropriações que realizaram, considerando as concepções de área, objetivos do componente, conteúdos de ensino, orientações didáticas e formas de avaliação contidas no documento.

Sobre os instrumentos para coleta dos dados, foi empregada a análise de conteúdo documental, especificamente dos PCN - Educação Física ( $3^{\circ}$ e $4^{\circ}$ Ciclos), o que teria permitido elaborar um instrumento de coleta junto aos professores de Educação Física, participantes da pesquisa, componentes do grupo focal. Tais procedimentos tiveram a 
finalidade de "[...] interpretar, como também desvelar, problemas e avanços no cotidiano da Educação Física face às indicações dos Parâmetros Curriculares Nacionais" (p. 57). ${ }^{24}$ Nas análises de conteúdo documental dos PCN Educação Física ( $3^{\circ}$ e $4^{\circ}$ Ciclos), foi destacada a intenção de detectar quais poderiam ser as proposições inovadoras para a área, considerando-se o que já se consolidara, historicamente, em relação às práticas pedagógicas para a disciplina.

Sendo assim, por meio de uma cuidadosa leitura do documento, buscamos indícios que possivelmente desvinculavam as aulas de Educação Física do anterior viés em busca da melhoria da aptidão física ou dos aspectos psico-biológicos presentes na trajetória histórica do componente. Nossa análise permitiu desvelar propostas onde a dicotomia corpo-mente não estava presente; que colocavam a Educação Física como um componente curricular integrado ao construto coletivo da escola e que alentavam para uma ação didática onde as aprendizagens fossem construídas pelos alunos de forma significativa (p.57).

Este processo de análise permitiu a constituição das categorias (4), pelo critério léxico, que orientaram as discussões no 'Grupo Focal', sendo elas os conceitos de 'inclusão' e ‘avaliação'; 'conteúdos' e ‘blocos de conteúdos'.

A técnica utilizada para coleta de dados foi a de "Grupo Focal" que, considerando os conteúdos dos documentos, de acordo com as categorias elaboradas, teve como propósito possibilitar apreender as interpretações teóricas por parte dos professores participantes, assim como, possíveis consequências para as práticas pedagógicas escolares em Educação Física.

Um grupo composto por sete professores de Educação Física com atuação no Ensino Fundamental ${ }^{25}$ foram contatados previamente por carta-convite para participar de um debate sobre ' Os saberes da Educação Física Escolar', sem que fosse antecipado qual seria o tema específico da reunião.

\footnotetext{
${ }^{24}$ Foram destacadas, após a coleta de dados, duas questões principais para verificação: a) em que medida a organização dos Parâmetros Curriculares Nacionais ensejou pistas para uma nova prática educativa? b) se as práticas dos professores de Educação Física alinham-se aos pressupostos expressos nos Parâmetros Curriculares Nacionais? (p. 57)

${ }^{25}$ Os critérios para escolha dos integrantes do Grupo Focal foram o de serem professores de Educação Física, atuantes no ensino fundamental e com algum tipo de acesso aos conteúdos dos PCN em sua formação continuada ou em preparação para concursos públicos. (p.60)
} 
A adesão dos professores foi voluntária. Participaram da reunião os sete professores informantes, a moderadora, o observador e um professor convidado. Utilizamos para registro do trabalho, a gravação em áudio e em vídeo, bem como preparamos um material que havíamos preparado anteriormente para suscitar o debate entre os professores (p.60).

Com a finalidade de caracterização dos participantes, quatro do sexo masculino e três do feminino, foi solicitado ao final do encontro o preenchimento com alguns dados por meio de um 'questionário' com itens relacionados à faixa etária; 'tempo de atuação na Educação Física Escolar; segmento de atuação (infantil, fundamental, médio); 'natureza da instituição escolar, se privada ou pública; horário coletivo de trabalho, como reuniões pedagógicas; frequência de participação nesses encontros e dados quanto a sua formação acadêmica de pós-graduação. Considera a autora que,

Há razões para crer que esse grupo, por meio de diversas oportunidades formativas como cursos de graduação recentes, cursos de extensão e pós-graduação e os momentos de formação contínua no interior das escolas, as temáticas presentes nos documentos tenham sido desenvolvidas e apropriadas pelos informantes (p. 62).

Quanto ao local de realização da coleta de dados, foi organizado um único encontro, em um sábado à tarde, numa sala de aula da Faculdade de Educação da Universidade de São Paulo, gravado em áudio e vídeo, foi garantido o sigilo sobre as informações coletadas assim como sobre a identificação dos participantes, tendo como,

[...] único fim, a coleta de dados para questões referentes à Educação Física Escolar'. Com duas horas de duração, encerrada a coleta de dados, foi dado início um diálogo com o grupo no qual se constatou que os professores não associaram a temática do encontro com discussões referentes aos PCN (p.63).

Quanto à coleta de dados no grupo focal, foram apresentados trechos extraídos dos textos dos PCN, de vídeos sobre aulas de Educação Física e instrumentos completos de avaliação utilizados por outros professores. Como recurso para suscitar um ambiente adequado para análises e discussões, foram elaborados roteiros com questões problematizadoras que abordaram temas que se referiram aos objetivos da Educação Física Escolar; aspectos conceituais como cultura corporal e seus elementos, jogo, lutas, danças, ginástica; a relação Educação Física e o exercício da cidadania. 
Questões sobre as concepções de Educação Física dos participantes, procurando evidenciar pontos de aproximação e distanciamento em relação às ideias apresentadas nos PCN, considerando-se as categorias elencadas a priori de inclusão, conteúdos e avaliação. Especificamente em relação ao conteúdo esporte, foram desenvolvidas questões sobre como seriam desenvolvidas suas aulas, se com ênfases na melhoria da aptidão física, do desenvolvimento motor ou contribuindo para o exercício crítico da cidadania.

Foi apresentado um vídeo que tematizava a seletividade dos alunos nas aulas de Educação Física Escolar, entre os que ‘jogam bem’ e os que ‘jogam mal’, com roteiro de questões que buscaram problematizar a competividade, a participação de alguns e a inclusão de todos nas aulas de Educação Física. Um outro vídeo foi apresentado, que abordava o 'Cálculo da Zona Alvo', de caráter mais 'teórico', para análises sobre as categorias de Conteúdos (conceituais, procedimentais e atitudinais) e Blocos de Conteúdos nos PCN, com questões sobre o entendimento desta terminologia; qual o tipo de aula de Educação Física seria mais comum e diferenciações em relação a outras formas de aulas.

Encerrando este tópico e tendo como categoria preferencial para análises neste momento a 'Avaliação', foram entregues dois instrumentos avaliativos em Educação Física Escolar, um de caráter mais quantitativo, mensurativo, valorativo, em forma de prova final e outro com registros e observações de caráter mais diagnóstico e formativo, qualitativo, como sugerido nos PCN, “[...] que possibilita uma intervenção sobre a prática em uma perspectiva processual no sentido de facilitar a observação do aluno no seu processo de construção de conhecimento" (p. 66).

Com intenção de procurar refletir sobre como os professores compreendem a avaliação em Educação Física, foram elaboradas questões que em seu roteiro abordaram temas como os modos de como realizam suas avaliações, com quais instrumentos, se com testes, provas escritas, observações, trabalhos de pesquisa; quais opiniões tinham em relação aos modelos apresentados, pontos positivos e problemáticos em ambas as propostas apresentadas e afinal, para que serviria a avaliação em Educação Física Escolar?

Gramorelli (2007) afirma que a pesquisa etnográfica possibilitará analisar as apropriações que se estabelecem entre as proposições sugeridas nos $\mathrm{PCN}^{26}$ e as ações

\footnotetext{
${ }^{26}$ Foram escolhidos os $3^{\circ}$ e $4^{\circ}$ ciclos - correspondentes ao Ciclo II do Ensino Fundamental - como a etapa da Educação Básica de enfoque para a investigação.
} 
realizadas pelos professores em suas práticas pedagógicas nas aulas de Educação Física em que "[...] a pesquisa etnográfica possibilitará olhar, ver e reparar se as proposições para as práticas dos professores de Educação Física do Ensino Fundamental se relacionam e incorporam as intenções propostas pelos Parâmetros Curriculares Nacionais (BRASIL, 1998a)" (p. 66).

Nas considerações finais, ressalta novamente como a análise documental realizada sobre os Parâmetros Curriculares Nacionais, $3^{\circ}$ e $4^{\circ}$ ciclos, (BRASIL, 1998a), teriam fundamentado a construção das quatro referências principais adotadas para análises ${ }^{27}$, que “[...] nortearam a investigação etnográfica junto aos educadores atuantes na Educação Básica que compuseram um Grupo Focal” (p.101).

\section{A prática pedagógica de educação física a partir do currículo de São} Paulo. Rocha, Robinson Luiz Franco da. 2014.

Rocha (2014), ao analisar as pesquisas educacionais que dizem respeito aos diferentes aspectos da cultura escolar, destaca a centralidades que os professores assumem nestes trabalhos quando se busca melhor compreender a realidade escolar, especialmente quando da abordagem das práticas pedagógicas em relação aos currículos, uma vez que para "[...] qualquer currículo que venha a ser implementado numa escola ou rede de ensino só pode vir a ser concretizado na realidade das aulas pela ação deles” (p. 49).

Tendo o 'estudo do caso etnográfico' como método de pesquisa, o autor se propôs investigar a implementação do currículo oficial do Estado de São Paulo a partir das experiências cotidianas vivenciadas em situações reais de aulas por uma professora da rede pública.

27 As categorias foram de inclusão, avaliação, de conteúdos e blocos de conteúdos. 
Em relação à determinação sobre quem seria a professora colaboradora, o pesquisador apresenta um relato sobre o processo e quais critérios de escolha foram utilizados. O primeiro foi o de que fosse efetiva na rede de ensino desde antes de 2008, período em que a Proposta Curricular do Estado de São Paulo para a disciplina de Educação Física (PCEF-SP) foram adotados na rede, de modo que o professor escolhido já tivesse dado aulas desde antes do período da implementação curricular. Além deste critério também foram elencados outros três:

(1) a preferência por um(a) professor(a) efetivo desta rede de ensino, por esta condição conferir maior estabilidade ao professor na rede, proporcionando que o(a) professor(a) lecione sem períodos de interrupção (que poderiam ocorrer caso o professor fosse eventual); (2) a escolha por um(a) professor(a) que estivesse há mais de um ano na mesma escola, por acreditarmos que este fator influencia consideravelmente a prática pedagógica, uma vez que, estando já há algum tempo na escola, o professor possui melhores condições de conhecer a realidade escolar na qual está inserido; e, (3) deu-se preferência por um(a) professor(a) que manifestasse desenvolver suas aulas com base no referencial curricular, uma vez que realizar a pesquisa com um professor que afirmasse não pautar suas aulas no referido material seria se afastar do objetivo proposto para a mesma (p.51).

Com indicações pela própria Coordenadora de Núcleo Pedagógico da disciplina de Educação Física, da Diretoria de Ensino de Limeira (DEL), de oito nomes de escolas, como afirma 'de memória', que havia professores que se enquadrassem no perfil desejado, o pesquisador - também professor efetivo da mesma rede e residente da cidade de Rio Claro - dirigiu-se a três delas, uma vez que não era intuito ir a todas as instituições indicadas e sim encontrar uma que melhor se adequasse às finalidades da pesquisa e que aceitasse sua realização, o que seria o suficiente para se dar o fim das buscas.

Na primeira escola, em uma região central de Rio Claro, o que facilitaria o acesso, em contato com a coordenadora pedagógica, explicou os motivos de sua visita, sendo informado que a professora da disciplina se aposentaria e que não saberia da disposição dela em aceitar a pesquisa. Foi dito, ainda, que a escola costuma receber muitos estagiários e que isso, naquele ano, deveria mais uma vez acontecer. Por conta desses fatores, essa primeira instituição foi descartada.

$\mathrm{Na}$ segunda escola, também no centro da cidade, relata como muito boas a receptividade e disponibilidade pela coordenação e professor, respectivamente. Entretanto por não conseguir entrar em contato com a direção da escola, para autorizar a 
frequência às aulas, cuja finalidade seria a pesquisa, optou-se pela terceira escola, que foi visitada logo em seguida.

$\mathrm{Na}$ terceira escola, houve contato com a coordenadora, mas como nenhum professor de Educação Física fora encontrado agendou-se uma segunda visita, para que se pudesse contatar a professora responsável pelas aulas da manhã. Nesta segunda visita, enquanto se dirigia com a coordenadora ao encontro da professora, a direção da escola ofereceu a possibilidade de realizar a pesquisa, desde que houvesse o aceite da professora e o encaminhamento dos documentos necessários para autorização junto à instituição.

Em contato com a docente para explicações sobre as intenções e procedimentos para a realização da pesquisa, o aceite pela Professora 'Lola' foi dado, sendo marcado para a semana seguinte o retorno para início dos trabalhos de campo. De acordo com a disponibilidade de dias e período conforme o horário da professora (terças e sextas feiras pela manhã) e considerando um comentário feito pela mesma acerca das diferenças significativas existentes no desenvolvimento das aulas. De acordo com cada uma das classes, o pesquisador julgou relevante o acompanhamento e realização de atividades de pesquisa em mais de uma classe de um mesmo ano, sendo assim escolhidas três classes dos nonos anos.

É feita uma apresentação inicial, com fins de contextualização das descrições e discussões feitas na escola e com a professora, tomando cuidados para garantia do anonimato tanto das pessoas envolvidas como da própria instituição, sendo apresentadas algumas informações básicas sobre a "Escola Rio Branco", com fotos e da "Professora Lola”. O autor se vale de considerações de Fonseca (1999) que aponta a importância de que sejam apresentadas pelo menos referências mínimas sobre o lugar sociológico e histórico dos sujeitos envolvidos.

Localizada na periferia da cidade de Rio Claro e inaugurada em 1988, a escola possui aproximadamente 1000 alunos, com idade entre 11 e 18 anos, estudantes do Ensino Fundamental - Ciclo II e Ensino Médio. Com 28 classes em funcionamento nos três períodos (manhã, tarde e noite). 
Destaca-se que há um número expressivo de alunos oriundos de outros estados brasileiros, principalmente de estados do Nordeste. Dentre as poucas informações fornecidas por esse documento, dá-se atenção ao fato de que considerável parcela dos alunos reside com avós e tios e que aproximadamente $60 \%$ dos pais e responsáveis estudaram apenas até o Ensino Fundamental, 30\% concluíram o Ensino Médio e somente 4\% possuem diploma do Ensino Superior. Entre os 6\% restantes, 1\% são analfabetos e 5\% não concluíram o Ensino Fundamental (p.55).

Com uma estrutura física que apresenta uma construção em dois pisos com secretaria, sala da direção e coordenação, diretamente ligadas, dois banheiros de uso dos funcionários, uma sala de informática, sala de vídeo, pátio interno com escada de acesso ao piso superior. Cantina, cozinha, sala de materiais de Educação Física, banheiro masculino e feminino, a sala dos professores, uma sala de despensa e mais duas salas de aula ao final do corredor. No piso superior, são encontradas oito salas de aula e uma sala de almoxarifado. Ao lado do prédio há a quadra descoberta, um pátio descoberto e um estacionamento para uso de professores e funcionários.

Sobre os espaços utilizados para as aulas de Educação Física, além da quadra, outros espaços também serviram à realização de observações, como as próprias salas de aula, os pátios externo e interno e a sala de vídeo. Sobre as condições de conservação dos espaços relata que a quadra não tinha cobertura e seu piso apresentava várias irregularidades, além de uma aspereza que causava várias quedas e arranhões aos alunos, segundo depoimento da professora.

Ao lado da quadra, uma arquibancada se constituía como espaço relevante para as aulas, pois por possuir sombra, servia aos alunos que ouviam as explicações da professora ou esperavam para participação nas atividades.

No mês de abril ainda foram fixados algumas mesas e bancos de concreto entre as árvores, que foram bem aceitos pelos alunos. Esse espaço é todo cercado por grades, embora em várias partes existam "passagens" nos locais onde o arame foi cortado. Pelo que percebi, essas passagens cumprem facilitar a recuperação da bola quando esta cai para além do alambrado dentro ainda dos muros da escola (p.57).

O pátio externo mesmo não sendo destinado para fins de aulas, em alguns momentos, era utilizado por alunos para a prática de jogos de voleibol em círculo, com uso raro, duas vezes, de rede. Com a fixação de mesas e bancos de concreto, o espaço também era utilizado para o jogo de 'damas', sendo que em uma única vez foi utilizado para que meninos jogassem futebol. 
Sobre o pátio interno como local usual para as aulas de Educação Física, destaca seu uso nos dias de chuva como único disponível para práticas corporais, como capoeira e movimentos do hip-hop, igualmente utilizado para jogo de damas e tênis de mesa.

A sala de vídeo foi utilizada em diferentes situações nas aulas, com projeção de filmes sobre de hip-hop, propagandas e regras sobre o futebol de campo e para as apresentações pelos alunos sobre seus times de Futebol.

O pesquisador considera importantes as características sobre os locais em que foram realizadas as observações, pois colaboram para o entendimento das descrições feitas posteriormente, uma vez que "[...] a ampliação e a limitação das possibilidades de realização das aulas por conta das condições físicas e de materiais é uma questão latente que precisa ser considerada" (p.60)

Sobre a professora, são apresentados dados sobre o local de nascimento, idade, estado civil, número de filhos, sobre a instituição em que realizou a formação inicial e a razão da escolha pelo curso de Educação Física. Aborda aspectos sobre sua infância e relações familiares e de como foram sua vida escolar e algumas de suas experiências nas aulas de Educação Física no Ensino Fundamental e Médio. Trata também de temas relativos à sua graduação e início da prática profissional um ano após sua formatura, período em que inicia sua pós-graduação lato-sensu em Educação Física Escolar.

Ainda sobre suas atividades profissionais, relaciona concursos públicos prestados, assim como sua experiência como sócia proprietária e professora de uma escola de Educação Infantil, por 18 anos. Após se desfazer da escola, presta concurso público em 2005 que a efetiva na rede estadual paulista de educação. Discorre sobre problemas de saúde que a afastam da sala de aula por um período de três meses no ano de 2006 e de suas dúvidas sobre continuar ou não como professora da rede pública.

\footnotetext{
Alguns aspectos pesavam muito para que ela pensasse em não se manter como professora da rede estadual paulista, como a quantidade de alunos por classe (na sua experiência com ensino infantil as salas tinham bem menos alunos), a falta de materiais e uma inadequada estrutura física para as aulas (as condições da quadra e o fato de ela não ter cobertura) e a indisciplina dos alunos (ela citou a ocorrência de agressões verbais por parte de alguns alunos que não queriam seguir as orientações dadas durante as aulas). Estes pontos, somados à ocorrência de sua doença, contribuíram para um profundo questionamento sobre sua continuação ou não no magistério paulista (p. 62-63).
} 
Dando sequência à cronologia, em 2007, relata uma nova ocorrência de problemas de saúde e seu afastamento por quase todo aquele ano. Em 2008, já em retorno às aulas, teve contato com os materiais curriculares o com as discussões em torno da implementação dos parâmetros curriculares do Estado de São Paulo, permanecendo, ainda, na mesma escola até o ano de 2010. Neste mesmo ano, ingressa em outro curso de pós-graduação latu-sensu em Educação Física Escolar, promovido pela Secretaria de Educação de São Paulo, para os professores da rede estadual. ${ }^{28}$

Ainda nesta escola, na cidade de Limeira, a professora Lola continuou lecionando nos anos de 2009 e 2010, ano em que ingressa em outro curso de pós-graduação lato sensu em Educação Física Escolar, agora oferecido pela própria Secretaria da Educação do Estado de São Paulo (SEE/SP) para os professores da rede, motivada pelas dificuldades encontradas em suas aulas de implementação do novo currículo, justificada pela ausência de capacitação adequada para trabalho com os materiais curriculares do PCEF-SP. Ainda em 2010, inicia uma segunda graduação, em Pedagogia, na mesma instituição que havia realizado a graduação em Educação Física, com objetivo de exercer cargos administrativos, em especial, o de supervisão.

No ano seguinte realiza remoção para a 'Escola Estadual Rio Claro', na cidade de mesmo nome, onde permanece em seu terceiro ano atuando como professora. Em 2012, complementa sua carga horária em uma outra escola da Rede Estadual. Em 2013, opta em lecionar apenas pela manhã para turmas dos $9^{\circ}$ anos do Ensino Fundamental e os anos do Ensino Médio, pois será neste ano também que acumulará, por concurso, mais um cargo como professora de Educação Física na rede municipal de ensino, exercendo assim atividades completas docentes pela manhã e tarde.

\begin{abstract}
Assim, na época em que as observações da pesquisa de campo ocorreram, a professora Lola atuava como docente efetiva da rede estadual de São Paulo na Escola Estadual Rio Claro no período da manhã (há pouco mais de sete anos na rede estadual e em seu terceiro ano nesta mesma escola), docente recém-contratada da rede municipal de Rio Claro, no período da tarde e cursava o último semestre de Pedagogia (ela veio a terminar em agosto de 2013, logo após o término das observações) (p. 65).
\end{abstract}

\footnotetext{
${ }^{28}$ O REDEFOR - Rede São Paulo de Formação Docente é um programa criado pela SEE/SP em parceria com o governo estadual e universidades públicas paulistas para oferecer cursos gratuitos de pós-graduação aos docentes da rede estadual.
} 
Rocha (2014) considera que foi com o mesmo intuito da apresentação de informações gerais sobre a escola e os espaços destinados para observações das aulas de Educação Física, que os dados apresentados sobre a 'professora Lola' e sua trajetória pessoal, acadêmica e profissional são abordados, sua localização 'sociológica e histórica' no sentido de colaborar para o melhor entendimento de seu cotidiano em suas práticas docentes.

Em relação ao trabalho de campo, foram realizadas observações no período de 5 de março a 18 de junho de 2013 (final das aulas do semestre), com duas entrevistas ao final nos dias 25 e 26 de junho na escola.

Definido o período, deu-se a escolha dos dias, turno e turmas $\left(9^{\circ} 1,9^{\circ} 2\right.$ e $9^{\circ} 3$ do Ensino Fundamental) em acordo com a professora. Deste modo, com três turmas, o tempo de observação foi ampliado, caso fosse escolhida apenas uma única turma.

Para os registros da pesquisa de campo, adotou-se um diário de campo, o qual era preenchido no momento das aulas. Nele, não apenas eram anotadas as situações observadas, como também um ou outro questionamento surgido e originado a partir daquilo que era visto (p.65).

O diário, então, era transcrito para formato digital, com complementações e reflexões sobre o processo de estudo, preferencialmente no mesmo dia das observações ou no máximo no dia seguinte.

Em função da grade horária, o número de observações variou significativamente, entre as observações ocorridas na terça-feira $\left(25-9^{\circ}\right.$, ano 1$)$ sendo em maior número do que as ocorridas às sextas-feiras $\left(20-9^{\circ}\right.$, ano $2 ; 9^{\circ}$, ano 3$)$.

\footnotetext{
Esta diferença se deu pela ocorrência de algumas interrupções das aulas de sexta-feira, tendo sido causadas por conta de: um feriado; convocações para realização de cursos na DEL (uma no mês de março e outra no final de junho); realização do Conselho de Classe ao final do primeiro bimestre; uma reunião para a discussão das avaliações aplicadas no início do ano e um feriado numa quinta-feira, que causou a interrupção das aulas da sexta-feira (p.66).
}

Foram realizadas observações de 70 aulas, em 25 dias, com cerca de 58 horas. Os temas abordados na sequência bimestral foram capoeira, hip-hop e futebol de campo, de acordo com o previsto pelo PCEF-SP. 
Quanto às entrevistas, foram realizadas após as observações, em dois dias, em função da amplitude de perguntas por etapa, (roteirizadas e em anexo ao trabalho). No primeiro dia as questões focaram a caracterização da professora abordando temas sobre seu percurso de vida e profissional (44 minutos); no segundo dia, as questões se dirigiram às especificidades do PCEF-SP, colocado em ação pela professora, tratando de temas sobre os materiais curriculares, das dificuldades encontradas para sua implementação e demais questões com base nas observações realizadas, (duração de 1 hora e 45 min.).

Com o cruzamento das informações obtidas com as observações, as entrevistas e o referencial teórico, o autor afirma que assim teria sido "[...] permitido alcançar uma melhor compreensão da maneira como a professora, colaboradora com o estudo, constrói sua prática pedagógica, a partir do que é proposto no PCEF-SP, as suas condições de trabalho e convicções próprias para a sua prática" (p. 67-68).

$\mathrm{Na}$ introdução, ao discorrer sobre sua trajetória acadêmica e profissional, em que apresenta aspectos sobre as origens e transformações de suas preocupações escolares, com materiais curriculares e práticas pedagógicas, considera a importância da participação na disciplina "Seminários Avançados em Educação Física Escolar", com o professor Jocimar Daolio, do Programa de Pós-Graduação da Faculdade de Educação Física da Universidade Estadual de Campinas (FEF-Unicamp), que também foi um dos autores PCEF-SP.

Cursando a disciplina de "Seminários Avançados em Educação Física Escolar", a intenção de cursar um mestrado foi amadurecida e, conforme afirma o mesmo ocorrendo com a perspectiva metodológica que seria assumida na pesquisa, pois " [...] importantes autores para este estudo me foram apresentados nesta época. Clifford Geertz, Claudia Fonseca e Roberto DaMatta alimentam uma perspectiva do trabalho etnográfico que aqui se optou por realizar" (p. 03).

Após apresentar a lista de cinco questões que orientaram seu projeto ${ }^{29}$, cujo tema abordado foi sobre os modos de "[...] como uma professora de Educação Física da rede estadual paulista constrói sua prática pedagógica, a partir do que é proposto no atual

\footnotetext{
${ }^{29}$ De que maneira os professores de Educação Física da rede estadual têm construído sua prática educacional com base na PCEF-SP? A PCEF-SP tem sido realmente integrada à prática dos professores da rede? Se sim, de que forma eles têm se apropriado dos materiais oficiais e como fica a questão da autonomia destes? Que iniciativas têm sido criadas e adotadas pelos professores frente à realidade na qual trabalham para colocar em prática o que é proposto no referencial curricular? (p.05-06)
} 
PCEF-SP.” (05-06), aprofunda as justificativas sobre a opção metodológica especificada "como um estudo de caso etnográfico",

[...] a opção por um método de pesquisa que possibilitasse olhar para a maneira como o (a) professor (a) desta disciplina conduz sua prática docente em meio à própria realidade escolar, e que, ao mesmo tempo, tornasse possível acessar as opiniões, objetivos, certezas e conhecimentos/saberes por detrás de seu comportamento. Percebeu-se a necessidade de olhar o cotidiano das aulas, conscientes de que esta se dá por um processo singular e complexo. Os professores desempenham suas ações de maneira única junto aos alunos e demais agentes escolares, diante da estrutura física e organizacional do contexto em que estão inseridos (p. 06).

Os referenciais teóricos adotados na 'orientação etnográfica' da pesquisa remetem-se a André (1995), que aborda a característica etnográfica de proporcionar maior proximidade do pesquisador aos próprios locais dos acontecimentos e a Geertz (1989) para quem a etnografia deve ser uma "descrição densa", resultado de " um tipo de esforço interpretativo",

A etnografia é, segundo Geertz (1989), uma "descrição densa" da realidade. Por uma descrição densa, o autor entende que realizá-la é tecer uma análise do comportamento dos sujeitos, de forma que não fique restrita a simples descrição superficial das suas ações, mas que se busque nela a interpretação dos atos e discursos como forma de entender o que está sendo “dito" por eles, não apenas em seus discursos, mas também nas suas ações mais rotineiras (p.06).

Em Fonseca (1999), aborda o aspecto da representatividade destes tipos de estudos, que derivariam de transformações das problemáticas iniciais, ocorridas em função do trabalho de campo,

[...] esta representatividade não é 'mecânica', do tipo que ilustra ou testa alguma afirmação geral, mas, segundo essa autora, seguindo-se os cuidados necessários a esse tipo de estudo, é possível que o dado particular abra caminho para generalizações, interpretações abrangentes, para a elaboração de modelos que nos ajudem a fazer sentido daquilo que os 'outros' fazem (p. 7-8).

Para compreensão do trabalho etnográfico empregado, já mencionado anteriormente como um 'estudo do caso', aborda a intencionalidade, em se considerando 
o tema, de procurar captar e interpretar durante o processo, os significados das ações e discursos de uma professora de Educação Física em suas aulas.

No seu segundo capítulo, são apresentados os critérios, procedimentos e motivos para escolha da escola, do (a) professor (a); relata como foram os primeiros contatos com a professora 'Lola', colaboradora da pesquisa e o encaminhamento da documentação e recolhimento das autorizações e assinaturas necessárias.

Sobre sua entrada em campo e preocupações iniciais, estava o modo de como se daria sua aceitação pela professora, funcionários e especialmente pelos alunos. Este processo de aceitação foi avaliado como bastante satisfatório; no relato, são apresentadas indicações de como se passou de um momento a princípio inseguro e com desconfianças, para outros com relações de cordialidade, empatia e reconhecimento do papel acadêmico ali desempenhado.

Dá o exemplo de Geertz (1989) que, com sua esposa, em Bali, Indonésia, no ano de 1958, após um incidente com a polícia e de terem tomado posição de fuga ao lado dos nativos, passam a receber - no lugar da indiferença vivida por ambos em seus primeiros dias -, o respeito e consideração da população local. Essa condição de aceitação, segundo Geertz (1988), teria tornado a pesquisa "[...] uma experiência etnográfica mais rica" (p.70), já que possibilitou acesso a informações que de outro modo não seriam possíveis de se obter.

Também aparecem, como preocupação para o pesquisador, possíveis influências que sua presença poderia acarretar em função da maior proximidade alcançada em relação ao fenômeno estudado, nos espaços e com os sujeitos envolvidos como, por exemplo, modificações das práticas pedagógicas, em suas formas usuais, desenvolvidas no cotidiano escolar pela 'professora Lola', em que, segundo o autor,

[...] é preciso aceitar que minha presença nas aulas ocorria sob a condição de "observador participante", pois, estando imerso na realidade das aulas, seria ingenuidade buscar alcançar uma "neutralidade". Na verdade, segundo DaMatta (1978), a descoberta nos estudos etnográficos ocorre a partir do relacionar-se, o que reforça a impossibilidade de o pesquisador se "neutralizar" frente aos sujeitos no decorrer da pesquisa. Mas ao mesmo tempo, o autor reforça o quão importante é o pesquisador "[...] calar e isolar-se" (DaMatta, 1978, p.33) em alguns momentos, como forma de não "participar" demasiadamente do contexto investigado. Essa era uma preocupação constante (p. 71-72). 
No capítulo 3 de título "A prática pedagógica da professora Lola: processo de 'retomada crítica"” do Currículo de Educação Física do Estado de São Paulo (CEF-SP), reafirma que a opção de fazer de sua pesquisa um ‘estudo do caso etnográfico' foi o que permitiu acompanhar a prática pedagógica da professora, durante 25 dias, nas 16 semanas de trabalho de campo.

Teria buscado acompanhar as aulas desta docente no seu acontecer diante das suas condições concretas de trabalho, de forma que fosse possível analisar a dinâmica com a qual esta realizava o trato dos conteúdos sugeridos no referencial curricular (foco do estudo), bem como outras situações não previstas (sugeridas) nos documentos curriculares.

\section{A Educação Física articulada ao currículo transdisciplinar. CASELLI,} Álvaro José. 2012.

Na pesquisa “A Educação Física articulada ao currículo transdisciplinar”, Caselli (2012) trata o tema da relação de um específico tipo de currículo institucional, transdisciplinar, com a disciplina de Educação Física ministrada na escola, campo de sua pesquisa.

Aborda uma estrutura curricular de Educação Infantil e Ensino fundamental I, baseada em um modelo internacional denominado Primary Years Programme, ${ }^{30}$ (PYP). A pesquisa busca estabelecer nexos entre as prerrogativas orientadoras éticas, metodológicas e avaliativas do programa e os seus efeitos pedagógicos nas aulas de EF.

Tendo como objetivos descrever e analisar as características de um programa curricular integrado (PYP), procura identificar modos de como a Educação Física se articula ao currículo integrado, organizado por temas transdisciplinares e unidades de investigação, considerando diferentes representações realizadas pelos dos professores(as) de Educação Física (p.18).

O autor propõe a realização de dois estudos, a descrição e análise das características e pressupostos do programa PYP e a articulação da educação física ao currículo transdisciplinar. No primeiro estudo, os sujeitos escolhidos foram os

\footnotetext{
${ }^{30}$ Programa dos Anos iniciais. Tradução livre.
} 
professores regentes de classe e professores especialistas de diversas áreas e, para o segundo estudo, somente os professores de educação física.

A opção metodológica é denominada como um estudo do caso etnográfico, que envolve uma descrição densa, com análise de documentos e realização de entrevistas, caracterizando-se,

[...] por uma investigação qualitativa, de natureza descritiva (THOMAS e NELSON, 2002; TRIVIÑOS, 1987), mais especificamente por um estudo de caso etnográfico, onde foram privilegiados os registros e a compreensão das questões que envolvem o estudo a partir da perspectiva dos seus sujeitos (p.66).

Com André (2008), corrobora a ideia do uso da terminologia de estudo de caso etnográfico para investigações sobre práticas pedagógicas, a partir de critérios que a autora considera relevantes nesta determinação metodológica, como os enfoques voltados mais para 'o que' e 'no como' que estas práticas se configuram do que em seus resultados; de aprofundamento na complexidade e totalidade de um fenômeno particular, institucional, pessoal ou curricular e quando da busca de inéditas correlações a partir da proximidade proporcionada pelo trabalho de campo desenvolvido. O pesquisador, então, afirma ser adequada sua escolha da metodologia etnográfica, pois sua pesquisa aborda um programa curricular específico, de uma determinada instituição em suas articulações com a disciplina de Educação Física.

Em relação aos instrumentos de pesquisa, com base em Lankshear e Knobel (2008) e Günther (2006) afirma que as análises de documentos expressam posições oficiais da instituição, oferecendo elementos que colaboram para elaboração, obtenção e interpretação de dados coletados diretamente junto aos sujeitos, por meio de outros instrumentos como entrevistas, observações e registros das notas de campo.

Neste sentido, foram analisados documentos oficias do IB - organização que implanta, supervisiona e assessora as instituições escolares que desenvolvem o programa analisado - e outros produzidos por coordenadores e professores que atuam na instituição escolar.

No Estudo I, com finalidade de caracterizar o Programa Curricular Integrado (PYP - Primary Years Programme), três documentos são destacados: o "Making the PYP happen - A curriculum framework for an international primary education", elaborado pelo IB (International Baccalaureate), documento orientador curricular oficial para 
escolas que desenvolvem o PYP (Primary Years Programme); o "Chronological Programme of Inquiry" - documento de referência para o planejamento anual; o "Yearly overview" - baseado no Programme of Inquiry explicita os objetivos de aprendizagem por área do conhecimento e o "Unit planner", com todas as etapas de orientação para investigação em cada uma das unidades (p.70-71).

O roteiro para análise dos documentos apresenta a caracterização do PYP em seus principais elementos com a identificação e missão dos programas do IB; a sequência de unidades de investigação, por ano escolar, com os elementos da organização curricular disciplinar e transdisciplinar; os objetivos de aprendizagem considerando a área de conhecimento - unidades de investigação e o planejamento do professor de classe de acordo com a unidade de investigação.

Para o segundo estudo, com objetivo de caracterizar as articulações entre a disciplina de Educação Física ao PYP, organizado por temas transdisciplinares e unidades de investigação, considerando as representações dos professores (as) sobre o programa curricular, foram listados os seguintes documentos: a estrutura geral do planejamento anual (PE Yearly over view); o planejamento das unidades de investigação (PE Unit planner) e o planejamento semanal das aulas de EF. Por ocasião das análises, procurou destacar relações entre os blocos temáticos e as unidades de investigação durante o ano letivo; os objetivos da Educação Física em relação ao PYP e os elementos dos planos semanais considerando os dois documentos anteriores.

As entrevistas semiestruturadas reflexivas foram realizadas com três professoras de Educação Física, da Educação Infantil e do Ensino Fundamental, com roteiro constante, em anexo, o qual contém questões antecipadamente tratadas com os próprios entrevistados, de acordo com os objetivos do segundo estudo, de identificação de representações destes professores sobre o PYP.

Alguns aspectos são destacados sobre as características do instrumento 'entrevista semiestruturada reflexiva', como a elaboração de um roteiro pré-estabelecido, aberto a questões emergentes do diálogo com os sujeitos, (GÜNTHER, 2006), com flexibilidade no estabelecimento da ordem das questões (THOMAS; NELSON, 2002) e os riscos de extrapolação de limites das questões - excesso de flexibilidade, ou de delimitação rigorosa. (GOLDENBERG, 2009). O caráter reflexivo que acompanha o procedimento de entrevista é atribuído ao processo dialógico estabelecido por considerações e confirmações pelo próprio entrevistado, sobre as interpretações e assertivas apresentadas pelo entrevistador sobre as respostas obtidas. 
No segundo estudo, foram realizadas entrevistas com três professoras de Educação Física, com identificação do local, dos participantes, data, início e duração, com questões sobre tempo de formação; de experiência como professor de Educação Física Escolar; atuação na instituição pesquisada; formação específica no PYP; entendimentos sobre o currículo integrado e transdisciplinariedade; sobre convergências e divergências entre suas crenças filosóficas, pedagógicas e as do PYP; restrições e limites impostos do PYP ao programa específico de Educação Física; sobre os modos de articulação entre a Educação Física e as unidades de investigação; as formas de participação nos planejamentos, colaborativo e do departamento de EF; uma avaliação das categorias sugeridas no documento do PYP para a Educação Física - desafios individuais, jogos, composição de movimentos, desafios de aventura, fitness e saúdepara a área específica; dificuldades encontradas e mudanças ocorridas na prática pedagógica.

$\mathrm{Na}$ entrevista com a professora do $6^{\circ}$ ano do ensino fundamental, o tema foi sobre a unidade de investigação em processo de finalização, denominada "Descobertas Científicas", realizada na sala dos professores de Educação Física em dois dias (ambas transcritas em anexo). Nas datas de 10/11/2010 das $14 \mathrm{~h} 15 \mathrm{~min}$ às $14 \mathrm{~h} 37 \mathrm{~min}$, com duração de 27 minutos e a segunda entrevista no dia 17/11/2010 das $10 \mathrm{~h} 00 \mathrm{~min}$ às $10 \mathrm{~h} 15 \mathrm{~min}$, duração de 15 minutos.

Destaca a importância das conversas e dos esclarecimentos da professora sobre a metodologia empregada, para realização das aulas com pesquisas, realizadas pelos alunos, orientadas por uma abordagem transdisciplinar. Quanto às atividades desenvolvidas, foram listadas avaliação diagnóstica com questões e tarefas ligadas ao tema, tais como, diferença entre descoberta e invenção, quais as descobertas mais importantes e por que, entre outras.

Ainda de acordo com a professora de classe, a organização curricular transdisciplinar proporciona uma articulação menos estereotipada das disciplinas, nos processos de investigação pelos alunos. A professora discorre sobre a importância do equilíbrio entre o que o professor (a) ensina e o quanto ele (a) guia e supervisiona a descoberta dos alunos, destacando pontos em relação aos conteúdos da área de linguagem, matemática, estudos sociais e as habilidades transdisciplinares.

Consta também da entrevista um comentário sobre as possiblidades de conexões na unidade estudada e a disciplina, dando como exemplo "[...] a ideia de discutir estudos científicos relacionados ao esporte ou atividade física, tais como os efeitos do uso de 
anabolizantes no esporte ou o desenvolvimento de equipamento voltado para o alto rendimento" (p.114).

Sobre as entrevistas com as professoras de Educação Física, roteirizadas, transcritas e em anexo, após identificação das participantes, o autor elabora um quadro sintético com discussão sobre os dados obtidos. As entrevistas foram realizadas na sala dos professores (as) de Educação Física da instituição entre os dias 17 e 19 de agosto de 2011. As questões que nortearam as entrevistas são apresentadas pelo pesquisador em apêndice.

A Professora A atua na Educação Física da Educação Infantil (Alpha 2, Reception e Transition) e Ensino Fundamental I ( $1^{\circ}$ e $5^{\circ}$ ano); teve entrevista realizada em 19/08/2011, início às 12h52min com 19 minutos e 43 segundos de duração.

A Professora B de Educação Física atua na Educação Infantil (Alpha 3, Reception e Transition) e Ensino Fundamental I ( $6^{\circ}$ ano), também é Coordenadora de Educação Física na Educação Infantil; a entrevista foi realizada em 17/08/2011, iniciada às 16h18min com duração de 31 minutos e 45 segundos.

A Professora C de Educação Física, atua na Educação Infantil (Alpha 2) e Ensino Fundamental I ( $2^{\circ}, 3^{\circ}$ e $4^{\circ}$ ano); a entrevista foi realizada foi em 19/08/2011, com inicio às $11 \mathrm{~h} 25 \mathrm{~min}$ e duração de 35 minutos e 52 segundos. 
SINTESE DAS RESPOSTAS E PRINCIPAIS IDÉIAS ELABORADAS NAS ENTREVISTAS

\begin{tabular}{|c|c|c|c|c|c|}
\hline & & Foco das perguntas & PROF. A & PROF. B & PROF. C \\
\hline \multirow{4}{*}{ 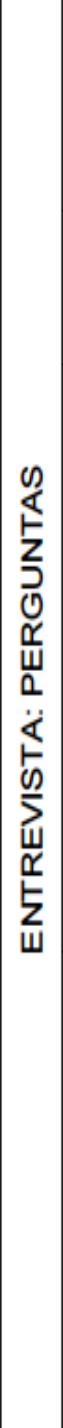 } & E.P1 & $\begin{array}{l}\text { Tempo de formação } \\
\text { em educação física }\end{array}$ & $\begin{array}{l}2 \text { anos e } 6 \text { meses } \\
\text { licenciatura. }-4 \\
\text { anos e } 6 \text { meses } \\
\text { bacharelado }\end{array}$ & 8 anos & 6 anos \\
\hline & E.P2 & $\begin{array}{l}\text { Tempo que atua na } \\
\text { Educação básica }\end{array}$ & 2 anos e 6 meses & 7 anos & 7 anos \\
\hline & E.P3 & $\begin{array}{l}\text { Tempo de trabalho } \\
\text { na instituição da } \\
\text { pesquisa }\end{array}$ & $\begin{array}{c}1 \text { ano como } \\
\text { professora e } 6 \\
\text { meses como } \\
\text { assistente. }\end{array}$ & 4 anos & $\begin{array}{c}1 \text { ano como } \\
\text { assistente e } 1 \text { mês } \\
\text { como professora. } \\
\text { Atuei, enquanto } \\
\text { assistente, durante } 4 \\
\text { a } 5 \text { meses como } \\
\text { professora do } 20 \text { ano } \\
\text { do ensino } \\
\text { fundamental, como } \\
\text { parte do treinamento. }\end{array}$ \\
\hline & E.P4 & $\begin{array}{c}\text { Curso - treinamento } \\
\text { PYP }\end{array}$ & $\begin{array}{c}2 \text { cursos: } 1 \\
\text { introdutório com o } \\
\text { coordenador do PYP } \\
\text { da escola e outro } \\
\text { chamado Making the } \\
\text { PYP happen } \\
\text { (organização } \\
\text { curricular, como } \\
\text { utilizar o programa } \\
\text { nas aulas - com } \\
\text { certificado IB) }\end{array}$ & $\begin{array}{c}2 \text { cursos: } \\
\text { Introdução ao PYP } \\
\text { com o coordenador } \\
\text { do PYP da escola } \\
\text { e planejamento } \\
\text { colaborativo (este } \\
\text { com certificado IB) }\end{array}$ & $\begin{array}{c}2 \text { cursos: } 1 \\
\text { introdutório com o } \\
\text { coordenador do PYP } \\
\text { da escola e outro } \\
\text { chamado Making the } \\
\text { PYP happen } \\
\text { (organização } \\
\text { curricular, como } \\
\text { utilizar o programa } \\
\text { nas aulas - com } \\
\text { certificado IB) }\end{array}$ \\
\hline
\end{tabular}

Quadro síntese com as perguntas e respostas dadas pelas professoras nas entrevistas realizadas. (CASELLI, p. 118-122, 2012)

Com base nas respostas oferecidas pelas professoras sobre currículo integrado e transdisciplinariedade, o pesquisador afirma não ter sido possível perceber um domínio adequado dos conceitos e mesmo sobre a diferença entre eles. Convergentes em alguns pontos, divergentes em outros, nas respostas denotavam-se dificuldades das professoras na na apreensão e domínio dos pressupostos conceituais e metodológicos da proposta curricular transdisciplinar. 
As respostas indicam a necessidade de uma reflexão mais aprofundada dos conceitos centrais da organização curricular transdisciplinar, objeto deste estudo. O entendimento desses conceitos é fundamental para os professores (as) compreenderem o trabalho pedagógico desenvolvido na instituição (p.124).

Sobre as crenças filosóficas e pedagógicas pessoais e o que consta no PYP, o pesquisador indica haver um consenso entre as três professoras sobre uma "[...] educação holística que busque a formação integral do aluno e que esta formação seja para a vida" (p.125).

Aspectos em relação às restrições ou limitações quanto aos temas transdisciplinares e o programa disciplinar de Educação Física não foram detectados e o que prevaleceu foi o entendimento de ser apenas um modo diferente de estruturação curricular, ainda que, segundo a Professora C, existam algumas dificuldades de compatibilizar o planejamento com o cotidiano escolar em sua dinâmica.

No que tange à observação participante, foram realizadas observações em três situações: algumas reuniões de planejamento colaborativo; atividades de preparação pedagógica; ${ }^{31}$ encontros formais-informais com os professores (as) especialistas (Educação Física, Línguas, Arte, Música, Teatro e Apoio Individual) e professoras regentes de classe. Os registros se deram com gravação de áudio e respectivas transcrições, com enfoque nas relações estabelecidas entre os conteúdos disciplinares e as unidades de investigação. Todas as reuniões foram realizadas em inglês.

As observações são documentadas através de notas de campo, instrumento que possibilita registros de situações ou diálogos planejados ou não, desde que sejam identificados como elementos importantes no contexto da pesquisa (p. 69).

Sobre a reunião com os professores e as possibilidades de conexões entre a Educação Física e as unidades de investigação, foi elaborado um roteiro com

\footnotetext{
${ }^{31}$ As 'Atividades De Preparação Pedagógica' são reuniões realizadas antes do início do ano letivo, com finalidades de planejamento. Com participação da diretoria geral, coordenadores e professores. Em alguns momentos, os trabalhos são realizados coletivamente, mas predomina o trabalho entre professores dos mesmos segmentos, Educação Infantil e Ensino Fundamental. Os professores de Educação Física se dividem de acordo com o número de aulas em que atuam nos dois segmentos.
} 
identificação dos participantes, data e horário, seguido de descrição sintética das falas dos professores.

Com base nas indicações de Boni; Quaresma, (2005) e Proença, (2008) considera que as orientações para os procedimentos de observação participante devam se dar a partir da compreensão da importância da proximidade estabelecida entre pesquisador-sujeitos e pela condição de inserção do pesquisador no próprio contexto de relações sociais nas quais se dão as ações.

O roteiro de análises das observações do planejamento colaborativo, realizado na escola, incluiu as orientações básicas das reuniões, com data, horário de início e final, participantes de cada reunião e as relações entre as unidades de investigação e as diferentes áreas do conhecimento. Para as atividades de preparação pedagógica, foram relacionados o cronograma de atividades e suas descrições.

$\mathrm{Na}$ observação de aula do $6^{\circ}$ ano, sobre a unidade de investigação "Descobertas Científicas' foram considerados data, horário e participantes, registro das falas, ações e recursos utilizados pela professora e alunos. Sobre as conversas com a professora de classe, com data, horário e participantes, foi levado em consideração o modo de introduzir uma unidade de investigação e a transdisciplinariedade em ação.

Também foram descritas e analisadas duas reuniões de planejamento colaborativo, organizadas por diretores (da Educação Infantil e Ensino Fundamental) e o coordenador pedagógico do PYP; presentes, os professores (as) de classe e especialistas, com objetivo de construir um mapa curricular, de estabelecer relações entre as disciplinas específicas e as unidades de investigação.

As reuniões analisadas foram referentes à primeira unidade de investigação, com início previsto para o dia primeiro de agosto de 2011. Os objetivos dessas reuniões foram familiarizar e aprofundar conhecimentos nas articulações disciplinares de acordo com as unidades de investigação, levando em conta o tema transdisciplinar e a ideia central. Após exposição do coordenador do PYP, os professores fizeram colocações sobre como realizar o trabalho de articulação pedagógica em suas disciplinas, com oportunidade de apresentação de pontos de concordâncias e divergências em relação ao documento principal. Foram detectados na fala dos professores, modos de conexão entre as disciplinas e unidades de investigação, mas não como estas de fato, pedagogicamente, aconteceriam mesmo que de forma esquemática; apareceram, ainda, falas relativas às experiências anteriores que, se por um lado, podem balizar o trabalho a ser realizado, poderiam incorrer no risco de manifestar como reprodução contínua do que já foi feito, 
ignorando-se, por exemplo, o que os alunos do então corrente ano poderiam acrescentar ao processo.

Reunião 1. Classe: Reception (Educação Infantil - grupo de 4 a 5 anos) Íntegra da transcrição no anexo I. Data: 01 de agosto de 2011 Início: 14h00m. Final: 14h50m. Participantes: Coordenador PYP, professoras de classe, coordenador de artes, professora de português, professoras de educação física e o pesquisador Álvaro Caselli (Coordenador de Educação Física).

Foi abordada a unidade de título "Brinquedos e brincadeiras", com a ideia central de que brincando se pode aprender e se divertir juntos. As linhas de investigação seriam a de caracterização dos jogos individuais e em grupos, do presente e do passado e a criação de regras com atitudes esperadas de cooperação, integridade e tolerância, com conceitos-chave de função e causa e conceitos relacionados de amizade, confiança e equidade.

No início da reunião, foram explicados os motivos da presença, da gravação e modos de coleta de dados pelo pesquisador. Em seguida, o coordenador do PYP explica que a ideia central de cada unidade, deve estar diretamente relacionada ao tema transdisciplinar: "quem somos nós". É feita uma leitura sobre o tema, tal como apresentado no documento "Making the PYP happen" (IB, 2009), no qual seriam destacados elementos como "[...] família, amigos, comunidade e cultura, direitos, responsabilidade e o significado de ser humano" (p. 97).

De acordo com o manifestado pelos professores, as ideias e atividades sugeridas foram de observação das brincadeiras das crianças e suas próprias regras; de jogos em grupo com regramento determinado; vivência de brincadeiras e brinquedos do passado com os pais e familiares, (Professora de classe). Atividades de desenho e pintura em jogos individuais e coletivos, com referências nas obras de Portinari e Ivan cruz sobre brincadeiras infantis. (Professora de Artes); linguagem e vocabulário referentes a jogos e brincadeiras como jogar, apostar, cirandar com prática de jogos, brincadeira e cantigas de rodas populares brasileiras, (Professora de Português) e proposições de jogos da cultura popular e de aprendizagem de regras com participação dos pais, (Professores de Educação Física).

Sobre os conceitos relacionados, a discussão com os professores abordou a amizade como condição para que as crianças possam brincar juntas; equidade como o direito de ser reconhecido, inclusive na sua diferença; e confiança com objetivo de que 
as crianças compreendam "[...] se confiam e o porquê de confiarem. As ênfases nessa faixa etária recairiam, portanto, no entendimento a partir da experiência." (p.100)

$\mathrm{Na}$ segunda reunião, manteve-se a estrutura da anterior, com título da unidade, 'Nenhum homem é uma ilha'; ideia central, comunidade organiza-se de diferentes formas, com linhas de investigação, variedade de comunidades e tomada de decisões em diferentes sociedades; características de diferentes organizações e de sistemas de governo, comunidades no mundo animal. Atitudes de cooperação e empatia. Conceitoschave discutidos: função, conexão, perspectiva. Conceitos relacionados de cooperação e network. Os professores de classe realizam proposições, apresentam ideias e sugestões de atividades.

A aula observada foi a do $6^{\circ}$ ano do ensino fundamental sobre a unidade de investigação "Descobertas Científicas". Realizada no dia oito de novembro de 2011, no horário 13:05 às 13:50. Os sujeitos participantes foram a professora de classe e os alunos.

O título da unidade de investigação foi 'Descobertas Científicas' (Scientific Discoveries), com o tema transdisciplinar 'Como funciona o mundo' (How the world works). A Ideia Central: Há um processo para descobrir o conhecimento sobre o mundo natural (There is a process for uncovering knowledge about the natural world), com as seguintes linhas de investigação: descobertas famosas e as pessoas que as fizeram (Famous discoveries and the people who made them); métodos usados em descobertas científicas (Methods used to make scientific discoveries e descobertas que estão acontecendo no momento (Discoveries that are being worked on). A atitude esperada seria a 'Curiosidade' (Curiosity); com conceitos chave, forma e conexão (Form and connection e conceitos relacionados: evidência e avanços tecnológicos (evidence and technological advances).

Com objetivo de compreender melhor como os conteúdos de várias disciplinas podem ser trabalhados dentro do contexto de uma classe, foi feita a observação da aula. O momento foi de fim e avaliação de unidade, com atividades de organização para participação de uma feira de ciências, após várias etapas didáticas já terem sido realizadas.

No relato constam elementos da aula em si, que teve início com a professora abordando o modo como os alunos, em suas pesquisas, seriam avaliados: a organização de uma feira de ciências e a apresentação dos resultados da sua pesquisa. Houve uma revisão das etapas de uma pesquisa, com exemplos no estudo, anteriormente, realizado 
pelos alunos a respeito da febre amarela. Na parte final da aula, foram anotados, em cartaz, os nomes dos integrantes dos grupos, tema, materiais e equipamentos para a feira.

Fotos documentaram os recursos utilizados em aula assim como do mural com os registros das etapas do processo de estudos sobre o tema "Descobertas científicas", com informações sobre a unidade, imagens de grandes cientistas, questionário dirigido aos alunos sobre seus conhecimentos do tema, um ranking, de acordo com os alunos, das maiores descobertas científicas para a humanidade e checklist sobre as principais etapas de uma pesquisa - (hipótese, lista de recursos, método, variáveis, registro de resultados, conclusão, uso de vocabulário científico).

Foram feitas observações na reunião somente com professores (as) de Educação Física, com apresentação de procedimentos didáticos e de avaliação com as articulações feitas pelos docentes de educação física, em relação a algumas unidades de investigação.

No dia 20 de junho de 2011, o pesquisador e coordenador da área de Educação Física $^{32}$ organizou uma reunião com os professores da disciplina para que estes exemplos apresentassem as conexões que buscam realizar com uma unidade de investigação. Algo que, provindo das atividades pedagógicas desenvolvidas, servisse de exemplo e referência para futuras atividades. Os registros de alguns momentos da reunião tiveram destaque sobre as experiências que professores expressavam das articulações feitas entre a disciplina de Educação Física, temas transdisciplinares e unidades de investigação:

Professora A: apresenta a descrição da unidade investigação, com tema transdisciplinar Quem somos nós? Título Nós todos crescemos, com ideia central todos os seres se modificam; com as linhas de investigação metamorfose, ciclos da vida das plantas, dos seres humanos e seu crescimento. São listadas, sequencialmente, as principais atividades desenvolvidas como a apresentação de conceitos sobre mudança e crescimento, vivências de habilidades motoras e jogos criados pelos alunos ou aprendidos com alguém em algum lugar.

Com os outros professores, as ideias centrais abordadas foram símbolo, meioambiente e mundo animal; com linhas de investigação sobre símbolos ao nosso redor e símbolos em diferentes épocas, escolhas do dia a dia, habitat e preservação, desenvolvidas em atividades de jogos de amarelinha e símbolos do tráfego; circuito com triciclos; procedimentos de segurança nos exercícios de ginástica; jogos de invasão proteção, com regras, punições inspirados em desenhos de TV.

\footnotetext{
${ }^{32} \mathrm{O}$ pesquisador declara atuar como coordenador da área de Educação Física na referida instituição.
} 
Nas análises, são destacadas as conexões feitas sobre os conceitos de crescimento, mudança e conhecimentos sobre o corpo; símbolos, brincadeiras e habilidades motoras; uso da quadra por humanos, pássaros e preservação da natureza.

Em relação às referências teóricas curriculares, para além do documento da instituição, objeto e referência para a dissertação, o pesquisador pontua considerações críticas acerca das formas hegemônicas de organização curricular. O modo como chama a atenção para a ideia de insuficiência do diploma de nível superior, como diferencial para a vida e no mundo do trabalho expressos na Proposta Curricular de Educação Física do Estado de São Paulo (2008) e o modo como acredita serem relevantes as propostas curriculares alternativas que levem em conta a organização curricular transdisciplinar.

\begin{abstract}
A partir da crença de que a concepção de currículo integrado e a organização curricular transdisciplinar podem oferecer respostas consistentes à questão da integração e responsabilidade compartilhada entre as disciplinas, o presente estudo pretende analisar um modelo de currículo integrado organizado por temas transdisciplinares, cuja estrutura central baseia-se no PYP (Primary Years Programme), programa de educação elaborado, organizado e supervisionado pelo IB - International Baccalaureate, e desenvolvido em algumas escolas internacionais no Brasil e escolas públicas e privadas em várias partes do mundo (p.16).
\end{abstract}

\title{
4. Marcas da religião evangélica na educação do corpo feminino: implicações para a educação física escolar. RIGONI, Ana Carolina Capellini. 2008
}

Nesta pesquisa, é assumido o referencial teórico das Ciências Humanas, com as contribuições da Sociologia e da Antropologia, com objetivo de relacionar a educação religiosa e as aulas de Educação Física Escolar, na educação do corpo dos fiéis. Foi realizada uma etnografia em uma Igreja Evangélica Assembleia de Deus, localizada na cidade de Campinas/SP.

Tendo em vista que o foco da pesquisa foi a cultura de um grupo específico e os símbolos que ela representa, a Antropologia foi a área de estudo que forneceu instrumentos mais apropriados a ela. Desde meu ingresso no curso de mestrado, tive um contato muito singular com os estudos antropológicos a partir de algumas disciplinas cursadas, por isso optei por realizar meu estudo nesta linha, utilizando especificamente a pesquisa etnográfica. (p.14) 
A pesquisa de campo foi feita entre março de 2006 e dezembro de 2007, com observação participante de cultos e encontros de formação; entrevistas semiestruturadas foram gravadas e transcritas, com membros da igreja, professoras de ensino religioso, o Pastor e meninas frequentadoras da escola de formação dominical.

\begin{abstract}
A coleta de dados (entrevistas) foi feita através da aplicação de um questionário elaborado de forma semiestruturada. Todos os depoimentos foram gravados, com a permissão dos entrevistados, para facilitar a transcrição e a interpretação dos dados. Todos os membros que participaram das entrevistas foram devidamente esclarecidos sobre as questões éticas do trabalho, como a garantia de sigilo quanto as suas identificações e a não publicação de imagens. Todos eles assinaram um termo de consentimento "livre e esclarecido" permitindo a publicação dos dados por mim registrados. Quanto às meninas que eram menores de idade, o termo foi assinado por seus pais consentindo com suas participações. (p. 61)
\end{abstract}

Com base em Geertz (1989), compreende que o que se faz em antropologia social é etnografia, que permite, com a entrada e aproximações em campo, criar discursos, descrever e interpretar os fenômenos culturais de grupos sociais distintos. Considera que esta abordagem ofereceu meios para se colocar na perspectiva dos sujeitos investigados “[...] compreendendo, assim, a lógica que rege as ações do grupo, ou seja, as razões pelas quais as pessoas agem da maneira como agem. Enfim, isto me oportunizou compreender o significado da construção do corpo a partir da religião evangélica" (p. 15).

As observações participantes focaram os gestos e comportamentos dos membros frequentadores da igreja Assembleia de Deus, familiarizando o estranho (Geertz, 1989), a partir do dia 1 de agosto de 2006, a pesquisadora passa a frequentar os cultos ${ }^{33}$ inserindo-se no contexto dos sujeitos em suas atividades religiosas de modo a estabelecer proximidades e relações de laços de confiança.

\footnotetext{
${ }^{33}$ As observações participantes totalizaram um número de 63 cultos. (p.62)
} 
No início, assisti a todos os tipos de culto praticados na Igreja, mas após perceber que todos tinham contornos parecidos, optei por dar maior ênfase aos cultos de domingo, tanto os da manhã como os da noite. Outro motivo que me levou a dar preferência aos cultos de domingo foi o fato de que era neles que se reunia o maior número de fiéis da Igreja, pois ele era "obrigatório" para toda família (seu nome já demonstrava sua importância), o culto da manhã era denominado de "Educação Dominical para a Família" e o da noite de "Culto da Família" (p. 16).

O enfoque das observações passava pelo que a igreja teria a dizer a respeito do corpo e sua presença em termos de gestualidades, compreender os significados atribuídos aos modos com que agem, com base em Mauss (2003), remete-se ao corpo em suas técnicas.

Há um estudo que chamou a atenção de Mauss e não por acaso. Este estudo falava sobre o aprendizado do nado, mas não sobre os aparatos biológicos do movimento. O artigo deixava de lado a "natureza" para demonstrar um interesse histórico e etnográfico da questão. $\mathrm{O}$ autor (que Mauss não cita a referência) falava sobre as mudanças que se podiam observar na maneira de ensinar o nado. Mauss (2003, p. 402) conta de forma descontraída como ele aprendeu a nadar e diz que na sua época era costume engolir água e depois cuspi-la. "Pois os nadadores se consideravam, em meu tempo, como espécies de barcos a vapor", diz o autor. E, o mais importante de tudo, Mauss complementa dizendo: "Era estúpido, mas, enfim, ainda faço esse gesto: não consigo desembaraçar-me de minha técnica". A mesma coisa podemos observar nas técnicas corporais aprendidas pelos fiéis das diversas religiões, técnicas estas que não são fáceis de modificar. [...] Tudo isto também pode ser observado nas diferentes religiões. Para o autor, um simples gesto que se faz com as mãos (e que é diferente de uma religião para outra) durante uma oração religiosa, é efetuado numa série de atos montados. "[...] e montados no indivíduo, não simplesmente por ele próprio, mas por toda a sua educação, por toda a sociedade da qual faz parte, conforme o lugar que nela ocupa" (MAUSS, 2003, p.408). É por isso que entendemos quando o autor fala que o corpo e suas técnicas estão ligados a símbolos morais (p. 54-55).

Um segundo local para as observações foi a 'Escola Dominical', que acontecia todos os domingos entre 09 e 10 horas da manhã, com participação de homens e mulheres, conjuntamente, realizando estudos e leituras indicadas em suas revistas de evangelização. Foi escolhida uma turma com cinco adolescentes meninas, considerando-se o fato de estarem nos anos finais do Ensino Fundamental. 
O grupo das meninas escolhidas conta com o trabalho de duas professoras que se revezam a cada domingo, são elas: Márcia e Vanessa. Em minha participação direta nas aulas da Escola Dominical, percebi que Márcia (já citada no capítulo anterior) parecia não gostar muito da minha presença. A outra professora, Vanessa, era muito simpática e não se importava com a minha participação nas aulas de evangelização. Pelo contrário, ela até me incluía na aula, dizendo que era para eu também falar se quisesse. Vanessa fazia doutorado na Unicamp e, assim como vários membros da Igreja, ela também não era de Campinas, veio da região norte do Brasil somente para estudar. Márcia também fazia doutorado na Unicamp e era do Paraná. Márcia parecia se sentir incomodada com a minha presença na aula, tanto que, várias vezes, ela sugeriu que eu não esperasse a aula terminar para iniciar minhas entrevistas. Ela sugeria que eu fosse para outra sala com uma das meninas que seriam entrevistadas, numa tentativa de continuar a aula sem mim. No entanto, quando eu perguntava se estava incomodando, ela, sempre muito educada, dizia que não. As duas professoras eram muito diferentes. Márcia era conservadora e tinha o semblante "fechado", já Vanessa era "mais moderna", apesar de usar as roupas comuns à Igreja, estas eram diferentes e mais alegres. Mas, em geral, fui bem tratada pelas duas (p. 87).

Sobre os aspectos mais relevantes detectados durante este momento das observações, denotam-se as diferenças de comportamento entre homens e mulheres, na relação discrição-indiscrição, durante os estudos dominicais, em que,

Enquanto um dos homens ensinava a lição em tom de voz muito alto em meio a algumas risadas nada discretas, que surgiam entre uma fala e outra, a mulher que ensinava a mesma lição no outro lado da Igreja falava em voz baixa (parecia muito acanhada) e sem nenhuma expressão de "graça" ou confiança no que dizia. Os homens que ouviam a lição falavam algumas vezes entre a fala do professor, emitindo exemplos e opiniões sobre o assunto (p. 78).

A pesquisadora ilustra com vários exemplos de ações e gestos realizados pelos fiéis na tentativa de se aproximarem mais de Deus, 
[...] voltados à redenção do fiel, como o dízimo doado por ele todos os meses à Igreja, as vestimentas, os gestos proferidos durante o culto e outros comportamentos corporais são facilmente observados na rotina deste grupo. Alguns têm ação direta, como o ato de se levantar e de se ajoelhar nos momentos corretos, as posições da mão no momento da oração, o jejum antes de algum ritual, etc. Outros agem sobre o corpo de forma indireta, como as roupas que alguns crentes precisam usar, os sermões que levam o fiel a modificar comportamentos, etc. Por tudo isto, percebi que o corpo é sempre influenciado, independente dos rituais agirem de forma direta ou indireta. Temos aí um conjunto de atitudes que foram educadas ao molde de um determinado grupo (neste caso um grupo religioso), e a isso Mauss (2003) chamou de técnicas corporais (p.56).

Em relação ao grupo das meninas, da mesma maneira foi possível observar características gestuais sobre modos adequados de se comportar para as mulheres, com situação de constante preocupação em relação às interpretações dadas aos seus movimentos,

Enfim, nas meninas que estudei, mais especificamente nas mais conservadoras, pude observar exemplos como o modo de sentar, os cuidados para se ajoelhar, as formas de cumprimentar, as maneiras comedidas de utilizarem o corpo, os gestos cautelosos sempre aparentando a necessidade de um cuidado excessivo com o corpo e outros. O uso da saia, por si só, é um limitador. Bruna e Paula tinham que tomar cuidado até para fazer um ritual de rotina, como o de se ajoelhar no chão. Dependendo do gesto que fizessem para se levantar, suas pernas apareciam "demais". Ou seja, a mulher deve se comportar de forma digna e, mostrar o corpo demonstra o apelo à sexualidade, algo a ser evitado para não causar tentação ao homem (p.111).

Durante o culto, as observações permitiram revelar significados expressivos como nos momentos de oração, na oralidade e nos gestos, nas exacerbações de sofrimento e no detalhamento correto dos movimentos e ritos. 
Outros exemplos relacionados ao corpo também foram observados. Os membros da Igreja estudada, ao rezarem durante os cultos, fechavam seus olhos num gesto que contraía toda a musculatura facial, transmitindo uma expressão de dor e sofrimento. Ao mesmo tempo em que pronunciavam palavras em tom de choro, apertavam os punhos com os dedos bem fechados como se este gesto simbolizasse a força que desejavam receber de Deus, a fim de suportar aquela dor que estavam sentindo. Há uma série de gestos que devem ser praticados numa cerimônia que envolve detalhes minuciosos. As mãos devem estar posicionadas corretamente, deve-se ficar de joelhos na hora certa, levantar na hora certa, permanecer numa certa posição pelo tempo necessário, enfim, são vários os exemplos de ritos corporais que compõem os mecanismos religiosos. São os símbolos contidos nestes movimentos que fazem deles o que chamamos de gestos (p.111).

A partir destas observações, realiza uma análise sobre as técnicas corporais e o ato de orar, pois uma vez que "[...] poderia ser feito apenas verbalmente ou mentalmente, não tem sentido para eles, se não expressar, através do corpo, os sentimentos necessários. Afinal, para os evangélicos estudados, o corpo deve atestar a crença de cada indivíduo " (p. 112).

As entrevistas semiestruturadas ocorreram a partir de fevereiro de 2007, num total de 16, quando a pesquisadora já se julgava mais inserida e aceita junto ao grupo de fiéis. Foram entrevistados membros da igreja, duas professoras e cinco alunas de uma turma da Educação Dominical e o Pastor, pois de acordo com a pesquisadora,

[...] entendi que ele era o modelo de indivíduo a ser seguido pelos membros da Igreja. Era ele quem repassava aos membros da Igreja o modo como deveriam se comportar e como deveriam educar seus filhos, afinal, ele era o "porta-voz" de Deus e poderia me esclarecer a respeito de questões as quais eu não conhecia, mas que, de certa forma, eu intuía que seriam importantes para o desenvolvimento deste estudo" (p. 17).

Os trechos que seguem são exemplos referentes às transcrições feitas das respostas dadas pelos sujeitos:

Deus pegou o pó da terra mais o pneuma, ou seja, o espírito, soprou seu ar e transformou em "alma vivente". Nós temos três elementos: o corpo, a alma e o espírito. O homem é um ser tricotômico. Olhando para esse ser, a alma é o elemento chave da vida do homem, é o elemento que decide, que questiona, a alma é o estado de decisão do homem. O corpo é a bainha da alma, o espirito é a relação que o homem tem com Deus, a necessidade de adoração e que existe em qualquer parte do mundo, uns podem adorar um animal, outros uma montanha, 
enfim, e os que adoram Deus, está intrínseco a nós a necessidade de adoração (Entrevista Pastor Roberto) (p.64).

A Santa Ceia é a representação simbólica de quando Jesus comemorou a última Páscoa com os discípulos, que ai ele partiu o pão e tomou o vinho e ele falou: Fazei isso em memória de mim até que eu volte, que é o que a gente crê, que Jesus vai voltar. Então a gente faz essa cerimônia, lembrando que ele morreu e que ressuscitou, e esta cerimônia é feita uma vez por mês (Entrevista Julia, professora da turma infantil) (p. 69).

A gente não usa saia porque é obrigado, a Igreja optou pela saia porque é um costume que a nossa sociedade sempre teve para marcar uma diferença (Entrevista, Márcia) (p. 80).

É tradição na nossa Igreja o uso da saia, mas se você pensar bem, vai lembrar que esta era uma tradição católica também. Se você for ver as mulheres mais velhas de hoje, todas andam de saia. Isso acontece porque a Bíblia manda a mulher se comportar com pudor e decência. Ela não pode ser alvo de atenção, ela tem que se vestir com simplicidade (Lúcio, marido de Márcia, na entrevista direcionada a ela) (p. 81).

Em relação ao roteiro e às questões direcionadas às meninas, três categorias foram tomadas como principais: aparência corporal, gestualidades, técnicas corporais e visões sobre as aulas de Educação Física. Foi estabelecido contato com as mães das alunas durante os cultos e com um dos pais.

Achei pertinente estabelecer contato e receber informações também dos pais das meninas selecionadas, até porque o modo de ser, principalmente das mães, poderia influenciar o modo de ser das filhas. Por isso, durante os cultos, sempre que tive a oportunidade me aproximei e conversei com as mães das meninas as quais me forneceram informações importantes. O mesmo não pude fazer com os pais, pois destes, dois não são evangélicos e dois praticamente não apareciam na Igreja. Por isso consegui conversar apenas com um deles, o Diácono local (p. 85). 
Abaixo seguem algumas das respostas dadas por cada uma das alunas durante os procedimentos de entrevista semiestruturada, referentes ao tema da Educação Física, a participação das alunas nas aulas e uma consideração sobre a dança, quando realizada em ambiente familiar:

Eles me acham diferente quando estou de saia. Por isso eu não gosto quando a professora dá uns exercícios que a gente tem que se abaixar muito ou fazer umas posições assim que os meninos ficam olhando e tirando sarro, sabe? Eu tenho vergonha de erguer muito as pernas, tudo que eu faço os meninos ficam falando besteira, sabe. Por isso que quando eu esqueço de levar o shorts eu nem faço Educação Física (Entrevista, Paula) (p. 133).

Uma vez a professora queria que as meninas dançassem a música do Leonardo, e eu disse que não ia dançar porque sabia que aquilo não ia agradar a Deus. Tinha uma amiga minha que era da Congregação $e$ que também sabia que aquilo não era legal e que nossa mãe não ia gostar. Daí a nossa professora falou "nossa, mas que religião mais besta”. Ai eu fiquei muito triste, porque assim, ela, ela não é evangélica, ela não sabe as coisas que eu sei (Entrevista, Bruna) (p. 134).

Ah, na época eu não via problema, era todo mundo mais criança, tipo na $1^{a}$ série nem dá nada você estar de saia, porque a gente nem sabe direito o que o preconceito significa. Eu até me lembro de me tirarem sarro porque eu era "crente", mas eu nem entendia direito que as pessoas me olhavam e me achavam estranha por causa da saia. Hoje eu sei que se eu fosse para a escola vestida igual às mulheres mais velhas aqui da Igreja se vestem, que é como eu me vestia, eu não iria aguentar, iam pegar muito no meu pé (Entrevista, Tais) (p.135).

Eu não gostava de ir para a escola. Ficava sempre com uma amiga minha que também era crente e que ia para a escola igual a mim. Sorte nossa que a professora de Educação Física não obrigava a gente a fazer aqueles exercícios, sabe? O problema não era só ter que ir de saia, o problema era que as minhas saias eram muito bregas. Acho que se na época eu tivesse umas saias pelo menos ajeitadinhas, não iam rir tanto, mas nem isso eu tinha. Depois que meu pai e minha mãe começaram a ganhar mais e eu pude ter umas roupas melhores. Mas dai eu já não queria mais usar saia (Entrevista, Telma) (p. 136). 
Nossa, quando eu vou para Campo Grande, na casa da minha tia, aí eu danço muito. (nesta hora ela respondeu com empolgação, mas rapidamente se arrependeu e foi logo "consertando" o que disse). Quer dizer, não sempre, mas é que lá na casa da minha tia ninguém é evangélico. Então todo mundo dança. Aí, estas músicas ficam o tempo inteiro na cabeça da gente. A gente acaba dançando. Minha mãe, tipo, eu percebo que ela não gosta, mas ela fala, ah, você que sabe Letícia (Entrevista, Letícia) (p.139).

Em relação às análises documentais, não foram identificadas referências explícitas, diretas, à utilização de referencial documental curricular ou de outra natureza nas análises e resultados da pesquisa, mas se considera a busca realizada na internet com a localização do site da igreja, uma atividade de análise documental que forneceu dados relevantes para a entrada em campo, assim como o aspecto legal das escolas confessionais,

\begin{abstract}
As escolas confessionais foram reconhecidas e garantidas desde a promulgação da primeira Lei de Diretrizes e Bases da Educação Nacional, de 1961. São escolas que oferecem, além do currículo convencional, a formação religiosa, possibilitando aos pais optarem pela escola que atenda aos valores religiosos escolhidos, em contrapartida ao ensino das escolas laicas (p.127).
\end{abstract}

Sobre o currículo e a obrigatoriedade do ensino da Educação Física no ensino fundamental e médio, refere-se à tensão estabelecida entre a disciplina, ou melhor, entre os conteúdos e atividades desenvolvidos em suas orientações didático-metodológicas e as interpretações religiosas a respeito do corpo e do profano. A Educação Física,

Inserida na vida das alunas que pertencem à crença religiosa estudada, pois é uma disciplina que compõe o currículo escolar obrigatório, ela está presente em seus cotidianos mesmo que algumas de suas atividades sejam consideradas profanas. Não que a aula de Educação Física em si seja considerada profana. Mas algumas atividades trabalhadas em aula não são "bem vistas" pelo grupo religioso, o que pode afastar as meninas evangélicas desta prática (p. 124). 
5. Educação Física escolar e relações de gênero: risco, confiança, organização e sociabilidades em diferentes conteúdos. UCHOGA, Liane Aparecida Roveran. 2014

Esta pesquisa trata do tema das relações de gênero nas aulas de Educação Física, abordando práticas pedagógicas com diferentes conteúdos. A escolha dos procedimentos de pesquisa abarcou a realização de um estudo etnográfico entendido, de acordo com Geertz (1989), como uma tentativa de reconstrução interpretativa de um conjunto de significados de determinados e complexos contextos culturais.

Sua caracterização, como do tipo etnográfica, remete-se às condições de tempo reduzido em campo, de pesquisador e sujeitos pertencerem à mesma cultura, com escolha e combinação de técnicas específicas como observação participante, entrevistas e análises de documentos. Também se afirma a centralidade do pesquisador como principal instrumento, mediando diretamente todo o processo e realizando as modificações se necessárias.

\begin{abstract}
A autora Marli André (1995), ao apropriar-se do conceito de etnografia e suas aplicações em pesquisas na área da educação, considera que o pesquisador/a na escola realiza um estudo de tipo etnográfico, já que normalmente o tempo de permanência deste na escola não é tão extenso quanto aos estudos que os etnógrafos fazem nas tribos e comunidades. Mesmo assim, de acordo com a autora, nesse tipo de pesquisa o pesquisador/a é o instrumento principal na coleta e na análise dos dados, assim, eles são mediados pelo instrumento humano, permitindo que este responda ativamente às circunstâncias que o cercam, de forma que ele modifique, se necessário, a forma de coleta de dados ainda durante o desenrolar do trabalho (p. 27).
\end{abstract}

Destaca o conceito de 'descrição densa' (GEERTZ, 1989), relacionado aos aspectos de maior aproximação e familiarização do pesquisador com o campo de estudo considerado na multiplicidade de possibilidades significativas existentes nos diferentes contextos, esse tipo de descrição permite estabelecer condições para interpretações sobre os significados que os sujeitos atribuem as suas ações.

Utiliza inicialmente a observação com anotações em diário de campo e conversas informais com professores e alunos. O critério para escolha do campo-escola foi com base no objetivo de realizar análises sobre relações de gênero nas aulas de Educação Física 
com conteúdos diversificados. Os professores, portanto, precisariam seguir os conteúdos da proposta curricular oficial do Estado de São Paulo, ainda que não em suas abordagens, mas em algumas das sequências sugeridas no documento. A opção feita foi ter como campo duas escolas em vez de uma, como indicado no projeto inicial, “[...] pela possibilidade de contrastar as duas realidades, buscando encontrar semelhanças e diferenças no que diz respeito às relações de gênero nas aulas" (p.32).

Considera que a importância de ter como critério para observações, escolas em que ocorressem aulas com diversificação de conteúdos, mas que não as caracterizasse como uma pesquisa dos conteúdos, mas sim nos conteúdos, parafraseia Geertz (1989), quando chama atenção para o fato de que os antropólogos (ou pesquisadora, neste caso) "[...] não estudam as aldeias (tribos, cidades, vizinhanças), eles estudam nas aldeias" (p. 29).

Seguem trechos das observações realizadas sobre situações ocorridas nas aulas de Educação Física. No primeiro, a pesquisadora descreve como um incidente com lesão, ocorrida em uma das aulas com uma aluna, provoca intervenção direta de pais e direção sobre os procedimentos didáticos da professora, com efeitos na participação dos meninos e meninas,

Outro fato que marcou as aulas de ginástica da escola Sônia foi a repercussão negativa que essas aulas tiveram para as mães de algumas alunas (e não alunos). Durante uma aula, a professora Laura relatou-me que em uma das $5^{\text {a }}$ séries uma garota havia estirado o músculo do pescoço enquanto realizava uma cambalhota. Devido à reclamação da mãe dessa garota e de algumas outras, a diretora "pediu" à professora que não obrigasse os alunos/as a realizarem as aulas práticas, dandolhes alternativas, como trabalhos e relatórios. Tal fato, ocorrido em outra sala, repercutiu na participação das meninas da $5^{\mathrm{a}} \mathrm{A}$, na qual eram feitas as observações desta pesquisa. Nas aulas que sucederam esse incidente com a garota da outra turma, as meninas passaram a participar ainda menos das atividades de ginástica artística, sendo que aquelas que se restringiam em realizar apenas movimentos mais fáceis (cambalhotas) optaram por fazer relatório e entregar trabalhos. Dessa forma, apenas oito das 18 meninas da sala participaram das aulas práticas nas seis aulas seguintes ao ocorrido na outra turma. O curioso é que o fato não interferiu na participação dos meninos. Se a reclamação das mães e a solicitação da diretora foram em função da possibilidade dos estudantes se machucarem, esse risco também não estava posto para os meninos? (p. 71). 
Neste segundo trecho, é dada a relevância às descrições feitas em relação ao contexto violento de uma das turmas, entre os meninos e entre meninos e meninas, com ofensas verbais e físicas, as diferentes reações, o modo como a instituição se colocava em relação à situação e a possibilidade de neste contexto violento ali estar representado parte da cultura da comunidade,

Um fato que chamou a atenção foi o número de ofensas verbais que os alunos das duas turmas dirigiam principalmente às meninas, as quais poucas vezes revidavam, sendo a atitude mais comum ignorar o fato. Entre os meninos também havia ofensas, que muitas vezes acabavam em brigas, pois esses, diferentemente das meninas, na maioria das vezes revidavam tais ofensas. As ofensas, na maior parte das vezes, referiamse à aparência física de meninos e meninas como "gordinho", "preto", "fedido", "mamute", "magrela", "orelhudo" etc., ou então referentes a conotações sexuais e/ou de gênero: "bicha", "chupa-rola", "puta", "vadia" essa última referida com muita frequência às meninas. Diversos meninos agrediam física e verbalmente outros meninos e também meninas. Havia certa conivência da escola com tal comportamento, não havendo intervenções específicas contrárias a essas atitudes no período em que estive presente na escola. Essa masculinidade agressiva, embora não fosse manifestada por todos os meninos, parecia ser parte da cultura daquela escola e provavelmente da comunidade na qual ela está inserida (p. 42).

As entrevistas foram realizadas com professores e professoras das turmas, após o primeiro bimestre de observações, assim como alunos e alunas com quem foram também estabelecidos diálogos informais, estes considerados fundamentais para entendimento dos acontecimentos observados nas aulas. Os alunos (as) foram escolhidos (as) com base nas observações, quatro meninos e quatro meninas, sob critério de envolvimento, dos (as) mais ou menos participativos (as) nas aulas. Feitas em duplas ou trios, em acordo com os pares de amizade e os tipos de participação.

Nas entrevistas com as professoras, ganharam importância os aspectos referentes à proposta curricular do Estado; a participação das meninas, comparações entre as formas de participação de ambos os grupos.

(Professora Júlia) Ah, acho que a maior parte dos conteúdos, independente da proposta, dá para trabalhar junto, sem problema, o que é ruim é muito aluno, mas diferenciar homem, mulher, não! Dá para trabalhar o conteúdo igual, claro que, geralmente, os meninos têm mais domínio do que as meninas, até porque os tipos de conteúdo 
também são muito mais do repertório deles, vamos dizer assim, do que delas. (...). Eu separo na hora do contato físico, que eu tenho mais medo de elas se machucarem, mas também aquela menina que se destaca eu deixo participar, sem problema. (...) é que também depende da classe, às vezes, têm meninos que se comportam superbem, não é um cara estúpido, que empurra, derruba. E tem menina que é mais habilidosa, se jogar com as meninas fica chato para elas (“...)” (trecho da entrevista realizada em 21/06/2010) (p. 65).

Em relação às entrevistas dos alunos (as), apresentam falas sobre os modos de que participam das aulas: a) de como um aluno, participativo nas aulas, revela uma postura de negação à prática do futebol e b) de alunas não participativas nas aulas, mas que afirmam realizar as mesmas práticas fora delas.

a) (Pesquisadora): De todas essas [atividades que fizeram na aula de EF] qual você mais gostou?

(Maurício): Da [atividade] de carriolinha e de pular corda!

(Pesquisadora): E ofutebol? Eu sempre vejo você jogando

(Maurício): Futebol... eu jogo, mas não gosto muito não, gostei mais da carriolinha e de pular corda

(Pesquisadora): E fora da escola, do que mais você brinca?

(Maurício): Ando de bicicleta, a gente faz campeonato para ver quem sabe mais coisas [acrobacias], como colocar rampinha, empinar [a bicicleta]. Só isso que eu faço (...)

(Pesquisadora): Futebol você joga?

(Maurício): Eu aprendi um pouco, mas eu odeio futebol! Odeio mesmo! [ênfase na fala]

(Pesquisadora): Mas nas aulas eu vejo você jogando

(Maurício): É de vez em quando eu jogo para os meninos parar de "encher o saco", mas eu odeio futebol! (trecho da entrevista realizada: 20/10/2010) (p. 96)

b) (Pesquisadora): E o que vocês fazem de atividade física fora da escola?

(Lais): A gente joga bola [futebol] com meninos e meninas

(Pesquisadora): Misturado? 
(Laís): Só jogamos eu e ela [Mariana] de menina, e um monte de meninos lá no campinho. Nós gostamos de fazer gol sem ninguém na barra [gol]

(Pesquisadora): E não tem mais meninas?

(Mariana): Quando tem a gente chama, mas é mais a gente mesmo.

(Pesquisadora): E os meninos são da mesma idade?

(Laís): É , quando nós não vamos [jogar], eles vão à nossa casa e chama a gente (risos).

(Pesquisadora): Mas aqui na escola vocês jogaram com os meninos?

(Mariana): Não, porque aqui na escola é muito ruim, eles não respeitam a gente

(Laís): É lá eles respeitam, porque não pode dar "bicuda", tudo isso! Não pode nada que doa!

(Mariana): Por exemplo, canelada, rasteira, derrubar a pessoa, violência, nada disso!

(Pesquisadora): Mas vocês gostam de jogar futebol?

(Laís): Gostar, nós gostamos, pra caramba! Nós jogamos todo o dia! $[\ldots]$

(Pesquisadora): E tem alguma coisa que vocês não gostaram nas aulas de Educação Física?

(Lais): Quando tinha que dividir o grupo, ai eu não gostava, porque separava a gente

(Pesquisadora): Separou como?

(Mariana): Assim, quando a gente jogava futebol, às vezes a dona

[professora] escolhia os grupos, ai era ruim porque ela nos separava! (Trecho da entrevista: $7^{a}$ série, escola Sônia 25/10/2010) (p. 103).

São apresentados documentos oficiais e uma lei. A Proposta Curricular do Estado de São Paulo; os 'Cadernos do Professor: educação física', da Secretaria Estadual de Educação e Decreto de Lei no 3.199, baixado em 1941, no governo Vargas.

Sobre a Proposta Curricular do Estado de São Paulo, especificamente sobre a disciplina de Educação Física, destacam dois conceitos-chave presentes no documento: o 'se-movimentar' (KUNZ, 1991) que considera a todos como autores de suas ações e 
não somente sujeitos condicionados estruturalmente pelas condições do meio em que se está inserido e 'Cultura de Movimento' (SÃO PAULO, 2008), que compreende as ações humanas em sua historicidade, importância e presença. Os jogos, as ginásticas, as danças e atividades rítmicas, as lutas e os esportes entendidos como expressões desta 'Cultura de Movimento' e, portanto, servem como referência para os conteúdos para a disciplina de Educação Física.

A abordagem do documento para a pesquisa se justifica pela indicação da diversidade de conteúdos para as aulas de Educação Física,

Embora o currículo não se proponha objetivamente a promover
igualdade de gênero, mas sistematização e diversificação dos
conteúdos, de forma que não sejam trabalhados apenas os quatro
esportes tradicionais (futebol, handebol, voleibol e basquetebol), o
objetivo desse trabalho foi investigar como essa diversificação interfere
nas relações de gênero, diminuindo desigualdades e promovendo
situações de convivência e aprendizagem coeducativas (p. 21).

O Decreto de Lei 3199 de 1942, mencionado na pesquisa, constitui-se como uma referência histórica sobre a participação da mulher em atividades físicas e esportivas comparada aos homens. O referido decreto, ao legislar sobre a matéria, restringe, direciona e delibera sobre as atividades físicas destinadas às mulheres, em seu artigo 54 trazia, “[...] Às mulheres não se permitirão a prática de desportos incompatíveis com as condições de sua natureza" (BRASIL, 1942)" (p. 15).

A pesquisa de campo teve início no mês de fevereiro de 2010, com contatos mantidos em escolas, de acordo com os critérios em relação ao professor: de que fossem efetivos na instituição e que seguissem os conteúdos de Educação Física, previstos na proposta curricular oficial. Com a seleção de três professores, em três cidades diferentes, inicia a observação em uma das escolas, em meados do mês de abril 2010. As outras duas tiveram início em maio e meados do mesmo mês.

Foram observadas turmas de $5^{\mathrm{a}}, 6^{\mathrm{a}}$ e $7^{\mathrm{a}}$ séries. Em um mês, foram observadas oito turmas nas três escolas, destas, duas foram selecionadas pela possibilidade de constatar realidades diferentes. Nas duas escolas denominadas como Sônia e Hortência, as observações se deram no período de dois bimestres, além dos dias dedicados às entrevistas. 
As entrevistas ocorreram ao final dos períodos de observações, cada entrevista teve duração de 15 a 20 minutos, todas roteirizadas e transcritas, em anexo e apêndices. Os documentos curriculares são utilizados como referência sequencial dos conteúdos.

Em relação à teorização sobre gênero, com base em Butler (2003), refuta binarismos e fixidez sobre as identidades de gênero e centraliza o debate sobre o domínio discursivo na elaboração das 'verdades' sobre os sujeitos, que justificariam desigualdades e diferenças nas aulas de Educação Física e em demais contextos.

\section{B. TESE}

6. Na "periferia" da quadra: educação física, cultura e sociabilidade na escola. 2010. OLIVEIRA, Rogério cruz de, 2010.

Esta pesquisa aborda o tema da 'periferia da quadra', quem são e o que fazem os alunos que não participam das atividades desenvolvidas nas aulas de Educação Física, para isso realiza uma etnografia sobre o cotidiano escolar dessas aulas, “[...] buscando identificar novos arranjos e outros pontos de vista para a dinâmica cultural dos atores sociais envolvidos - olhar de perto e de dentro" (p. 40).

Como referência do campo antropológico, baseia-se na Antropologia Urbana de José Guilherme Magnani que “[...] mesmo sem nenhuma menção à escola e à Educação Física, fornecem subsídios que fomentam novos olhares para se pensar a prática escolar da Educação Física” (p.40).

Valendo-se do entendimento de Magnani (2002) sobre as configurações dos "pedaços" em suas pesquisas urbanas, procura estabelecer paralelos com os acontecimentos que se apresentam em aulas de Educação Física. Considera a etnografia como um processo no qual o rearranjo de dados possibilita a ampliação das interpretações iniciais do pesquisador, numa atividade de compreensão de códigos, percepção de comportamentos e interpretações de significados.

A etnografia é entendida como uma atividade de compreensão de códigos, percepção de comportamentos e interpretações de significados que, de acordo com cada problema de pesquisa, procuraria filtrar, “[...] o dito e o não dito pelos atores sociais no que se refere à problemática de algum estudo" (p.49). 
Sobre a explicação etnográfica, com base em Magnani (2002), é um processo de rearranjo de dados que mesmo na impossibilidade de ser o do nativo, é ampliado em relação às interpretações iniciais do pesquisador,

Este novo arranjo carrega as marcas de ambos: mais geral do que a explicação nativa, presa às particularidades de seu contexto, pode ser aplicado a outras ocorrências; no entanto, é mais denso que o esquema teórico inicial do pesquisador, pois tem agora como referente o 'concreto vivido' (MAGNANI, 2002, p.17, grifo do autor) (p.49).

A importância do diário de campo é afirmada por neles constarem os registros que permitem estabelecer relações inéditas sobre o contexto observado uma vez que, “[...] durante a realização das primeiras observações e analisando, a posteriori, o conjunto de dados registrados no diário de campo, vários foram os eventos que corroboraram a existência de uma nova pista para o estudo" (p. 108).

Sobre as observações realizadas, os registros feitos a seguir dizem respeito às atividades desenvolvidas pelo professor e alunos em situação de aula livre; sua atuação como 'professor' de uma das turmas, mesmo na condição de pesquisador e a rede de sociabilidade estabelecida nas aulas de Educação Física.

Nas aulas livres, a condução das atividades era feita pelos alunos, na maioria das vezes, futebol; o professor atuava no controle do espaço, local, tempo para os meninos e meninas, distribuição de materiais e das relações conflituosas entre alunos,

$\mathrm{Na}$ espera pela vez de jogar, meninas e meninos ocuparam o tempo de várias formas: assistindo ao jogo da arquibancada, conversando com o professor, praticando futebol no anexo da quadra coberta, ouvindo música, dançando, ensaiando algumas brincadeiras como pega-pega ou, simplesmente, jogando conversa fora (p. 100).

Sobre os acontecimentos que tratam da aproximação, familiarização e aceitação de sua presença pelos alunos, relata os fatos ocorridos em sua $11^{\mathrm{a}}$ observação, que devido à ausência do professor da classe, recebe um convite da coordenadora pedagógica:

Assim, virei-me para a saída e já ia embora quando, da porta de uma sala, a coordenadora Mara me chamou. A mesma informou que o professor João não tinha ido à escola devido a uma paralisação programada pelo Sindicato dos Professores naquela tarde. Sem perder tempo, perguntou-me se eu tinha interesse em assumir a aula do professor. Naquele momento, mesmo sabendo que não cabia a mim tal função, resolvi aceitar em ficar com a turma. Seria uma ótima oportunidade para estreitar relações (p.106). 
Ao afirmar haver o estabelecimento de uma rede, sociabilidades entre os alunos que circulam na 'periferia da quadra', em que se dão relações de maior proximidade, em espaço com controles menos rígidos que os de sala de aula, com as práticas pedagógicas não diretivas, constata contradições existentes que permanecem em conflitos como os de gênero, por exemplo, no entendimento superficial sobre o esporte e as finalidades das aulas de Educação Física, pois nessa 'periferia,

[...] mesmo permitindo o contato livre e direto com o outro, podendo os alunos diferenciar-se, sendo mais que simplesmente alunos do $7^{\circ}$ ano podendo ser Elton, Antônia, Teresa, Marcos, Caio, Marcela etc., acabando por revelar um pouco de si: gostar de futebol, não gostar de futebol, demonstrar criatividade ("manchete" ao gol -, esboçar preconceitos, pronunciar-se quanto à falta de diversificação das atividades, comemorar aniversário, dançar, cantar, rir, ouvir música, ou, simplesmente, não fazer nada por qualquer motivo) - também leva ao conformismo declarado, esboçado nos conflitos de gênero, na prática irrefletida do esporte e na compreensão da Educação Física como um momento de sair da rotina rígida da escola, mesmo existindo o desejo de mudança (p. 137).

Foram realizadas entrevistas, todas roteirizadas e em apêndices, com a coordenadora pedagógica, com a professora de Ciências e com o professor de Geografia. Com o professor de Educação Física e alunos foram realizadas duas entrevistas, sendo que com os alunos foram feitas em grupos, para que ficassem mais à vontade. Houve a aplicação de um questionário que precedeu a realização das entrevistas com os alunos. As características quanto à entrevista semiestruturada, com roteiro de questões orientado pelos pressupostos da pesquisa, são tratados a partir de Triviños (1987):

\footnotetext{
De acordo com o autor, a entrevista semiestruturada é um dos principais meios para realizar coleta de dados numa pesquisa qualitativa, ao mesmo tempo em que valoriza a presença do investigador e oferece todas as perspectivas possíveis para que o informante alcance a liberdade e a espontaneidade necessárias, enriquecendo a investigação (p. 51).
}

Os trechos de entrevista aqui apresentados se referem aos conflitos pedagógicos e profissionais apontados pela coordenadora; as dificuldades de legitimação da Educação Física na escola, segundo o professor da disciplina; críticas do professor de Geografia ao modelo de gestão da instituição e a opinião de alunos sobre as aulas de Educação Física. 
A coordenadora, ao tratar da situação de municipalização da escola, atenta para o fato de que os professores passaram a escolher trabalhar naquela instituição, às vezes, independentemente de afinidade com a proposta pedagógica ou apreço à qualidade de ensino,

Então hoje nós temos alguns colegas que são mais antigos, que ainda mantêm essa proposta, que brigam por essa qualidade de ensino, $e$ temos também um grupo, que mesmo com uma formação e tudo, não tem uma preocupação tão grande em garantir a manutenção dessa qualidade [...] muitos estão vindo para cá por uma conveniência. Pela localização, por termos 25 alunos em sala - a maioria das escolas tem 35 ou 40 -, e não por acreditar na proposta da escola, de ter o desejo de fazer realmente um trabalho de qualidade aqui (Coordenadora Mara) (p. 84).

O professor de Educação Física (João) critica a condição de como a disciplina é tratada na 'Escola dos Sonhos', com o caráter atribuído de desarticulação em relação ao modelo formativo da escola, ao se levar em conta as demais disciplinas curriculares,

E a briga, no bom sentido, é exatamente essa, a gente gasta muito tempo tentando ocupar espaços dentro da escola que, no contexto geral, acham que não é nosso ou que nós não fazemos parte daquele espaço [...] como se a nossa disciplina não fosse uma disciplina curricular e existisse dentro da escola por mera imposição do sistema [...] muitas vezes [a escola] usa a Educação Física para estar solucionando outros problemas que acontecem dentro da instituição e que não teriam que ser cobertos com a disciplina da Educação Física (Professor João) (p.87).

O outro professor de Geografia (Anselmo) atenta para o perfil tradicional e conservador da escola, na qual um mesmo grupo de gestão administra de forma não democrática.

Já fui chamado atenção por várias coisas e sempre naquela conduta de chamar na sala, conversar, reprimir, oprimir [...] uma escola muito tradicional que se apega às avaliações para se ter regalias. Na última eleição para Direção da Escola, o slogan da candidata à reeleição, era 'Para que mudar?' Ora, não é mudando que a gente progride? Até o que já morreu muda, a biologia está ai para provar. Então é aquela coisa estática, que não percebe que as mudanças são bem-vindas. Acham que as mudanças ameaçam. Então deixaram transparecer que se mudasse a escola, perderia qualidade. (Professor Anselmo) (p. 88). 
Em relação aos alunos, o ponto destacado é o descontentamento destes em relação às atividades de Educação Física, quando desenvolvidas em sala de aula, pois as consideram ruins em oposição às aulas em quadra, que seriam melhores por nelas poderem brincar.

[Na sala] Ele [o professor João] fica falando, falando, falando e não adianta nada. Porque a gente vai ficar olhando para o lado e para o outro e não vai prestar atenção em nada. Mas agora, se ele chegar aqui na rodinha [na quadra] e ficar conversando com a gente, fazendo as perguntas aqui, ai seria legal. Porque você já foi criança e você sabe como é, aula na sala [de EF] não rola. Se ele desse o mesmo conteúdo de sala aqui [na quadra] a gente já iria gostar (Aluna Clara) (p.98).

Ao se referir a uma aluna (Sara) da $7^{\mathrm{a}}$ série, apresenta o comentário da mesma sobre o modo de como ela daria aulas de Educação Física, caso viesse algum dia se tornar professora, “[...] primeiro explicar os fundamentos. Depois, não jogar os alunos na quadra, mas mostrar como faz, ensinar tudo na prática mesmo" (grifo do autor), (p. 170). Chama a atenção a posição tomada pela aluna ao considerar sua quase que total ausência nas atividades desenvolvidas nas aulas de Educação Física, não podendo sequer ser classificadas de acordo com os 'pedacinhos' identificados pelo pesquisador, como os dos (im) praticantes, flutuantes e ativos.

Como atividade da pesquisa de campo, foram incluídas análises do Projeto Político Pedagógico da escola 2003-2005 e análises sobre o Plano de Ação da Escola para o ano de 2009.

No Projeto Político Pedagógico da Escola (PPP) consta o início do funcionamento da escola em 1988, primeiro como unidade federal de ensino (1988-1998) e posteriormente foi municipalizada. Situada dentro do espaço físico pertencente a uma universidade federal, continua sendo administrada pela instituição de origem, cabendo ao município gerir a lotação de professores e o desenvolvimento do projeto pedagógico. Entre os seus objetivos, destaca-se o de "possibilitar a realização de experiência e pesquisas no campo da Educação, contribuindo para a produção de novos conhecimentos na área educacional" (p.78). 
O Plano de Ações da Escola (2009) apresenta dados sobre o número total de alunos (403) e origens distribuídas pelos municípios (5), em que expressa que a diversidade encontrada por essa condição seja bastante positiva para as relações entre os alunos.

Com o melhor Índice de Desenvolvimento da Educação Básica (IDEB) do Estado, realiza sorteios de vagas para o primeiro ano do ensino fundamental, matutino (50) e vespertino (25), com mais quinze vagas destinadas à fila de espera. Com eleições para diretor a cada três anos, da administração participam também representantes de todos os segmentos da escola (pais, alunos, professores e funcionários). Os recursos financeiros são obtidos através de orçamento da municipalidade. Um aluguel é pago à universidade por conta da utilização do espaço físico e despesas como água, luz e telefone.

Em uma agenda fornecida aos alunos, constam informações sobre as regras de funcionamento da instituição, com resumo do PPP, que ao se referir à Educação Física apresenta em negrito e sublinhado: “Os alunos são dispensados das atividades físicas e não das aulas. Deverão permanecer assistindo às aulas regularmente e/ou realizando trabalhos, que serão determinados pelo Professor de Educação Física", o que parece indicar, conforme analisa o pesquisador, um caráter de se buscar legitimar a Educação Física como uma disciplina curricular, para além de somente práticas corporais ocorridas no ambiente escolar.

O decreto federal $\mathrm{n}^{\mathrm{o}} 69.450$, de $1^{\circ}$ de novembro de 1971 é mencionado para abordar as situações facultativas para dispensa das aulas de Educação Física, assim como a Lei 9393/96, das diretrizes e bases da educação, que torna a Educação Física facultativa nos cursos noturnos, em que continuaria a residir a " [...] ideia de que, para esse tipo de aluno, a Educação Física sobrecarregaria seu esforço físico, denotando a ideia de não haver uma sistematização do conhecimento, apenas uma prática. Assim, parece notória a ressalva contida na agenda dos alunos da 'Escola dos Sonhos"” (p.61).

Sobre o currículo não expressa referências aos documentos oficiais do estado ou do município para suas análises. Sobre aspectos curriculares e as teorizações em Educação Física dos últimos 20 anos, considera que estas não obtiveram impacto proporcional nas próprias práticas pedagógicas dos professores, pelo contrário. Concorda com a ideia de Bracht et al (2003) de se ter como tarefa permanente realizar análises sobre a Educação Física como disciplina do currículo escolar Pesquisas sobre o 'como fazer', como 'trabalhar' são importantes principalmente se aliadas a pesquisas sobre as intervenções pedagógicas realizadas pelos professores em que se buscaria compreender 
"[...] o que o chão da quadra tem a dizer sobre a dinâmica cultural da Educação Física. Para isso, configura-se como pertinente um denso incurso ao cotidiano escolar, permitido por um olhar de perto e de dentro (p. 45). 


\section{ANÁLISES E DISCUSSÕES}

Gramorelli (2007) define sua pesquisa como uma 'investigação etnográfica', em que se dá a utilização de uma técnica denominada 'Grupo Focal', no qual professores de Educação Física, atuantes em escolas, tornados colaboradores da pesquisa, são reunidos, por meio de convite e aceite espontâneos, participando inicialmente com desconhecimento das motivações principais do encontro, o que depois, ao final do encontro é informado, a citar: obter dados para uma dissertação de mestrado com objetivo de analisar a relação dada entre os pressupostos conceituais e metodológicos de um currículo oficial, os PCN, de âmbito federal, e as aulas de Educação Física nas escolas, segundo relatos sobre a prática pedagógica realizada pelos próprios professores em suas escolas.

Como segunda característica, a utilização das análises sobre referido documento oficial na elaboração da maioria das questões a serem aplicadas junto ao grupo focal. A realização de uma entrevista coletiva, com questões semiestruturadas e, ainda, a utilização de técnica indutiva com análise coletiva de excertos de texto, no caso também dos próprios PCN. Quanto ao tempo de contato direto, por meio do grupo focal, foi de duas horas com professores da rede púbica e privada, dos ensinos fundamental e médio.

A entrevista ocorreu por meio de perguntas comuns a todos, para discussão pelo grupo, relacionou questões com excertos dos documentos oficiais e registros de situações pedagógicas do cotidiano escolar em Educação Física; houve exibição de vídeos; gravações e anotações; abordou temas específicos da prática pedagógica contida nos PCN, a partir de quatro categorias eleitas a priori: Inclusão, Categorias de Conteúdo, Blocos de Conteúdo e Avaliação.

Gramorelli (2007), em seus resultados, encontra uma perspectiva inclusiva apresentada pelos professores para as aulas de Educação Física, com cuidados na adequação da seleção de conteúdos, atividades e metodologia com vistas a resguardar o sentido inclusivo.

Em relação a essa questão, identificamos que a participação dos alunos pode se dar por outros meios, como pesquisas, debates, análises de vídeos, imagens, textos, saídas pedagógicas, palestras, enfim, inúmeras alternativas que fazem parte de um amplo processo de ensino aprendizagem que não necessitam basear-se, exclusivamente, nos pressupostos do movimentar-se fisicamente (GRAMORELLI, 2007, p.102). 
Sobre a avaliação, mudanças são descritas no sentido inverso de um padrão mais tradicional na área tecnicista, classificatório e pautado em mensurações, para uma perspectiva formativa, processual do aluno, em sua aprendizagem e que oferece elementos para que o professor elabore revisões sobre encaminhamentos de suas próprias práticas pedagógicas.

Para os participantes, não basta o aluno realizar conteúdos de ordem apenas procedimental, ou seja, saber fazer/realizar determinadas atividades práticas, é importante que ele compreenda os conteúdos conceituais que se relacionam com a temática em questão, conhecer o que está fazendo, quais aspectos - políticos, econômicos, históricos, sociais - influenciaram e influenciam na construção dessas práticas, maneira pela qual contribui com a formação do cidadão crítico indicado nos PCN (GRAMORELLI, 2007, p.103).

Com base nas análises documentais e nas informações coletadas junto aos professores por meio de técnicas de entrevista e discussão em Grupo Focal, a pesquisadora indica haver uma aproximação entre a Lei de Diretrizes e Bases da Educação Nacional, Lei 9.394/96 e os PCN. Demonstra que tanto a lei de autoria Darcy Ribeiro (RJ), que teria desconsiderado importantes consensos do projeto de LDB 'Cidadã', como a produção e elaboração dos PCN foram instituídas no período de vigência do 'Plano Decenal de Educação' (1993-2003), sobre os marcos das políticas neoliberais, preconizadas para a Educação pelo Banco Mundial.

Em relação à pesquisa de Rocha (2014), denominado em sua metodologia como um 'estudo do caso etnográfico', o trabalho de campo foi feito em uma escola, acompanhando uma professora como observador participante, além de realizar duas entrevistas, uma ao início e outra ao final com a professora, com roteiros definidos em questões semiestruturas, sendo abordados aspectos de ordem pessoal, acadêmica e profissional, com 40 minutos a primeira entrevista e 1 hora e quarenta minutos, a segunda.

Foram 16 semanas de trabalho de campo, com 25 dias de observações de aulas. As anotações ocorriam no momento em que se observavam as práticas ou, no máximo, no dia seguinte. Sobre o local, os tempos e espaços de aula de Educação Física, a escola em termos arquitetônicos e a estrutura administrativa também é relatada. A análise do documento curricular oficial do Estado serve de orientação para as observações e elaboração das questões das entrevistas semiestruturadas. 
Na pesquisa, a abordagem do trabalho de campo se dá pela imersão do pesquisador no local de trabalho da professora colaboradora, uma escola, junto aos alunos, em suas aulas de Educação Física, durante aproximadamente quatro meses, com observações, aplicação de entrevistas, com questões semiestruturadas e elaboração de diário de campo, com anotações e questões sobre o observado naquele contexto.

A etnografia é, segundo Geertz (1989), uma "descrição densa" da realidade. Por uma descrição densa, o autor entende que realizá-la é tecer uma análise do comportamento dos sujeitos, de forma que não fique restrita a simples descrição superficial das suas ações, mas que se busque nela a interpretação dos atos e discursos como forma de entender o que está sendo "dito" por eles, não apenas em seus discursos, mas também nas suas ações mais rotineiras (ROCHA, 2014, p.06).

Rocha (2014) considera que a implementação curricular da Proposta Curricular do Estado de São Paulo tem causado significativas alterações nas aulas da disciplina de Educação Física, resultado das relações estabelecidas entre indicações contidas nos documentos e as leituras que dele fazem os professores em suas experiências pedagógicas junto aos alunos no cotidiano escolar.

No decorrer deste estudo foi possível encontrar indícios na prática pedagógica da professora Lolla de que a implementação curricular tem causado modificações sensíveis à prática educacional da Educação Física nas escolas paulistas. Modificações que não ocorrem apenas com base no que as "novas" orientações curriculares determinam, mas também a partir dos saberes experienciais dos professores na compreensão (leitura) que fazem de tais currículos e das dificuldades encontradas na realidade do contexto escolar e na relação com os alunos no acontecer diário das aulas (ROCHA, 2014, p.173).

Sobre a compreensão que a professora Lolla apresentou sobre suas aulas de educação física, são listados objetivos como o de ser um espaço para valorização da participação, envolvimento, socialização, gosto pela atividade física, de vivências para o lazer, desenvolvimento da autonomia, responsabilidade, de compreensão mais geral dos elementos da cultura de movimento e dos aspectos históricos, culturais e sociais dos conteúdos da Educação Física. A reunião desses objetivos comporia a expressão de um conjunto de saberes denominados experienciais, resultante de processos de retomadas críticas realizadas pela professora em relação ao documento oficial, processo esse “[...] 
por meio do qual os professores buscam transformar suas relações de exterioridade com os saberes de formação profissional, disciplinares e curriculares em relações de interioridade" (ROCHA, 2014, p.168).

O pesquisador constata que seria possível inferir uma elaboração de alternativa curricular, de acordo como denominado por Macedo et al (2004), pelas alterações promovidas pela professora na proposta curricular oficial no exercício de suas aulas, por inclusão, exclusão ou modificações das atividades nele sugeridas.

No seu estudo, Caselli (2012) caracteriza a etnografia efetuada como uma descrição densa, com realização de entrevistas e análises de documentos, na qual se deve privilegiar a compreensão da perspectiva dos sujeitos.

A pesquisa sobre um programa curricular em uma determinada instituição escolar e suas articulações com a disciplina de Educação Física são consideradas como propícias e adequadas para adoção do referencial metodológico etnográfico, uma vez que se ajustam aos parâmetros indicados por André (2008), para elaboração de pesquisas etnográficas em Educação, em que o trato de questões particulares, específicas, institucionais e curriculares são analisadas em suas características a partir da condição de proximidade estabelecida pelo pesquisador em campo.

As entrevistas semiestruturadas são realizadas com três professoras de Educação Física e uma professora de classe. O roteiro das professoras, com treze questões, encontrase no apêndice, assim como as transcrições das respostas. Abordaram assuntos como tempo de formação, de atuação em Educação Física, de trabalho na instituição, sobre o treinamento em PYP e sobre temas como as conceituações do currículo integrado, transdisciplinariedade; crenças filosóficas e pedagógicas; restrições entre o programa de Educação Física e o tipo de organização curricular; modificações nas práticas pedagógicas dos professores. A primeira entrevista com a Professora A, teve duração de treze minutos, 47 segundos; com a Professora B, trinta e um minutos, 45 segundos e com a Professora C, 35 min e 52 segundos. Com a professora de classe, a entrevista, tratada como uma conversa, transcrita e anexada, foi dividida em duas sessões; uma, com cerca de 20 minutos e outra, com 15 minutos. Os temas abordados pela professora foram destacados em 10 pontos, nos quais são apresentadas as práticas pedagógicas específicas, desenvolvidas com os alunos sobre 'Descobertas Científicas' em suas relações transdisciplinares. 
Discussão sobre as descobertas mais importantes para a humanidade: definição de um ranking das 10 mais, justificando o porquê. Aqui os alunos (as) tiveram que argumentar e fundamentar suas colocações. Para tal, tiveram que utilizar, portanto, de habilidades de pesquisa (como coleta e registro de dados), habilidades do pensar (análise e síntese) e de habilidades de comunicação (linguagem) para apresentarem e justificarem oralmente diante dos colegas. Tais habilidades (vide p.60-61) foram planejadas para serem desenvolvidas durante esta unidade (CASELLI, 2012, p.111-112).

Nas ‘Análises Documentais', são discutidos os documentos curriculares oficias da instituição, os planejamentos dos professores, por áreas e séries. O PYP o (Primary Years Programme), programa de educação elaborado, organizado e supervisionado pelo IB International Baccalaureate, é descrito e analisado de acordo com roteiro: Identificação da missão dos programas do IB e dos pressupostos e características e principais pilares do PYP, (Making the PYP happen - A curriculum framework for an international primary education"); identificação da ordenação cronológica em que ocorrem as unidades de investigação por ano escolar e os principais componentes que norteiam a organização curricular e o planejamento anual disciplinar e transdisciplinar (Chronological Programme of Inquiry); identificação da seleção dos objetivos de aprendizagem, por área do conhecimento, por unidade de investigação (Yearly overview); identificação das etapas do planejamento de uma determinada unidade de investigação feita pelo professor(a) de classe (Unit planner).

A ideia do perfil ideal do aluno estabelecido nos programas do IB
parece estar imbuída de um caráter de generosidade humana. O que
talvez se possa pensar é se, ao idealizar um sujeito, um aluno (a),
selecionando as qualidades desejadas e, portanto, valorizando-as, não
estaremos produzindo as diferenças e evidenciando e identificando em
outros alunos (as) o que não é desejável e, portanto, criando uma
possível discriminação e exclusão. Talvez este possa realmente ser um
risco que merece uma reflexão, que sem dúvida deve estar vinculada às
questões políticas que permeiam as construções curriculares (CASELI,
2012, p. 87).

Foi registrado em separado um depoimento não transcrito em anexo de uma professora de Educação Física, do $5^{\circ}$ ano, no qual se registra um modo de relação transdisciplinar realizado por uma professora de Educação Física a partir do tema "Como nos organizamos" e ideia central: "sistemas econômicos são essências para o funcionamento da sociedade". Com origem em atividades de classe, professoras e alunos 
decidiram relacionar as investigações com a EF. As linhas de investigação para abordagem da unidade foram: necessidade de trocas de produtos por recursos; relações entre demanda e fornecimento na sociedade; comparação de diferentes sistemas econômicos e o valor do dinheiro (CASELLI, 2012).

Como principais conceitos, aponta que surgiram os de perspectiva e causa, com foco na discussão sobre a quantidade de dinheiro envolvida no esporte profissional, especificamente, no tênis e no futebol. Algumas questões foram levantadas pela professora como o valor de alguns salários de atletas profissionais, quem teria os maiores salários, quem os paga. Outras questões surgiram relacionadas aos patrocinadores, investigadores, ingressos, etc., foram realizados recortes no tema e realizadas investigações individuais ou em grupos. Os resultados foram estruturados e apresentados. Foram desenvolvidas práticas desportivas do tênis e do futebol, assim como realizadas discussões críticas sobre a questão financeira e o âmbito do esporte profissional.

O pesquisador apresenta a seguinte questão: seria realmente necessária a abordagem de assuntos econômicos nas aulas de Educação Física? Considera que não, mas julga interessante que o trato de tais conteúdos, provindos da realidade, permitem conexões adequadas entre a disciplina e as proposições da unidade, em que ocorreriam a transferência e/ ou aplicação de uma ideia ou conceito para o contexto de um recorte específico (CASELI, 2012).

Rigoni (2008) realiza uma etnografia, participando de cultos e reuniões dominicais em uma escola de formação religiosa, um grupo com características e simbologias próprias. Os processos de pesquisa de campo com a criação de discursos, a partir de descrições e interpretações, teriam possibilitado apropriar-se dos significados que incidem sobre e corpo dos fiéis pela religião evangélica.

\footnotetext{
Para entendermos o fenômeno nos dias de hoje, utilizamos o autor contemporâneo Clifford Geertz e seus conceitos sobre religião. O autor nos fornece a compreensão do fenômeno religioso como algo dotado de significados que se modificam de sociedade para sociedade, ao longo do tempo (RIGONI, 2008, p. 17).
}

Suas observações ocorrem durante aproximadamente dez meses, com participação em 63 cultos. Com o tempo, passa a apenas frequentar os cultos dominicais, obrigatórios para os fiéis e com maior número de participantes. As observações são 
direcionadas aos gestos e significados expressos nos rituais, que de acordo com Marcel Mauss, apresentam em suas técnicas corporais uma simbologia moral.

\begin{abstract}
A partir daí, buscando familiarizar-me com o que me parecia estranho (GEERTZ, 1989), busquei respostas para as questões relativas à construção do corpo pela cultura religiosa. Busquei observar e documentar as ações cotidianas de um grupo específico. Minha intenção foi a de me colocar do mesmo lado do observado, incorporando-me ao grupo, ou seja, à Igreja, para poder participar de suas atividades religiosas. Observei os ritos e busquei compreender as crenças que possivelmente fazem parte do cotidiano do fiel desde a infância, colaborando para uma educação do corpo desde muito cedo. Busquei respostas para as transformações do corpo pela cultura evangélica (RIGONI, 2008, p. 15-16).
\end{abstract}

As observações na 'Escola Dominical', no horário das 09.00 às 10.00 da manhã, com seis alunas em fevereiro de 2006, que depois passaram a cinco, com a desistência de uma delas. Buscaram captar, registrar e interpretar gestos, movimentos, ações que caracterizassem modos comuns de identificação e posturas das meninas frequentadoras das sessões de formação religiosa dominical. Refere-se a Mauss e o sentido por ele dado ao termo técnicas corporais como,

[...] todos os gestos e formas de comportamento que possuem sentidos específicos, de acordo com a sociedade de que cada indivíduo faz parte e do tipo de educação que recebe. Cada costume que adquirimos em nossa vida cotidiana reflete-se no corpo de alguma forma. Os usos que fazemos de nosso corpo dependem de nossas escolhas no dia a dia (RIGONI, 2008, p. 108).

Com base em suas observações e com exemplo sobre o vestuário, descreve um dos processos de convencimento pela educação religiosa, relacionando a participação em determinada atividade com o uso de indumentária adequada.

Letícia usa saia, na maioria das vezes, para ir à Igreja. Ela tem ajudado a cuidar da turma de Educação Dominical das crianças, em alguns domingos. E nessa hora, o hábito do qual ela afirma não gostar se transforma em algo que a faz se sentir importante. Nestes dias ela vai para a Igreja de saia sem reclamar deste costume que antes a incomodava. Ela diz: eu tenho que dar o exemplo para as crianças mais novas, né? Esta pode ter sido a forma encontrada pela professora Márcia que foi quem a convidou, de envolvê-la e adequá-la aos costumes de uma forma mais sutil (RIGONI, 2008, p. 120-121). 
Entrevista membros da igreja, as professoras da Educação Dominical, as cinco meninas da classe de formação religiosa, algumas mães e o Pastor. As entrevistas são gravadas, mas não apresenta transcrições em anexo. Sem roteiro para a entrevista semiestruturada, aborda temas com o Pastor sobre a criação do homem; o destino das almas após a morte física; os sentimentos de crença tornados fé; rituais, sacrifícios, sacralidade, regramentos e como o corpo é compreendido como um comércio entre o fiel e Deus; a condição subalterna das mulheres e meninas em relação aos homens em termos de diminuição das liberdades e aumento das suas obrigações. Com a professora Júlia, trata de assuntos referentes aos rituais como batismo e a Santa Ceia, com consagração do pão e do vinho; com as alunas, abordou assuntos como os usos e costumes obrigatórios da religião, suas proibições, utilização de enfeites e adornos, usos da saia; sobre um dos pais ser forrozeiro', a relação com os pais, familiares, amigos, as experiências na escola e nas aulas de Educação Física.

[...] as preocupações com a alma representam apenas uma espécie de pano de fundo de uma repressão que objetiva conter o corpo feminino do pecado na terra. É preciso reprimir o corpo da mulher para que ela não caia e, principalmente, não provoque a tentação no homem. Para que isso seja viabilizado é preciso atuar sobre o corpo da mulher de alguma forma. A forma encontrada pela Igreja Evangélica Assembleia de Deus foi estabelecer regras quanto ao uso do corpo. Regras estas que se refletem na aparência da maioria das mulheres que são 'crentes' (RIGONI, 2008, p. 107).

Rigoni (2008) não explora documentos curriculares ou legislativos produzidos pelas professoras, alunos, membros da escola de formação ou da igreja. Faz menção ao IBGE (BRASIL, 2007), sobre o aumento da migração da população de fiéis entre a Igreja Católica para as Igrejas Evangélicas Pentecostais e a Lei de Diretrizes e Bases da Educação de 1961, para caracterizar as escolas confessionais. Com pesquisa em sítio virtual oficial da Igreja Evangélica Assembleia de Deus, não indicado nas referências bibliográficas, reuniu informações sobre dias e horários dos cultos e demais atividades da Escola Dominical. Diferentes cultos são listados como o da 'Celebração da Família', 'Estudos Bíblicos' e o da 'Santa Ceia'. 
Muito interessante era também o slogan que complementava o site da Igreja neste tópico de horários: Acompanhe os nossos cultos ao vivo pela Internet em áudio ou vídeo! E, caso você não se contente só com isso, venha cultuar a Deus conosco de corpo, alma e espirito (O grifo na palavra corpo é meu, pois o apelo das igrejas, não só das Evangélicas, é justamente a participação materializada dos fiéis. Não basta crer, tem que comparecer) (RIGONI, 2008, p. 59).

Uchoga (2012), ao abordar questões de gênero nas aulas de Educação Física por meio de estudo etnográfico, com pesquisas de campo em duas escolas, observa aulas, entrevista professores, alunos e analisa documentos curriculares oficiais. O pesquisador (a) é considerado como o principal instrumento na coleta de dados, atento às necessidades teóricas e instrumentais modificadas pela experiência de campo e questões dele emergentes (ANDRÉ, 1995). Busca apresentar os significados que os sujeitos dão às suas ações, com descrição densa, pelo efeito da aproximação e confiança estabelecidas entre pesquisador e sujeitos no local das ocorrências dos fenômenos culturais (GEERTZ, 1989).

Uchoga (2012) determina como campo para observações duas escolas, de acordo com os procedimentos didáticos dos professores (as) em relação ao currículo escolar oficial do Estado de São Paulo e os interesses da pesquisa em suas questões de gênero: que nas escolas escolhidas o professor (a) procurasse ministrar as aulas de acordo com os conteúdos constantes no documento oficial curricular, pelo menos na sequência de apresentação e não necessariamente pelas abordagens metodológicas indicadas no documento. Deste modo, procurou analisar a relação entre a diversificação de conteúdos nas aulas de Educação Física e as respectivas formas de participação de meninos e meninas. Foram feitas 128 observações de aula nas Escolas Sonia e Hortência, junto às professoras Julia e Laura, e Professor Gustavo, em turmas da $5^{\mathrm{a}}, 6^{\mathrm{a}}$ e $7^{\text {a }}$ séries. As observações foram registradas em anotações no diário de campo.

Após a apresentação dos vídeos, o professor arrumava os materiais usados com a ajuda de alguns alunos. Num dado momento, um garoto pertencente ao grupo de masculinidade 'dominante' dá um soco no rosto de outro garoto não pertencente a tal grupo, este por sua vez, começa a chorar. $\mathrm{O}$ fato é contado para o professor que os tira da sala para conversar. Um dos meninos vem até mim e diz 'Aí dona, esse menino é muito ruim de briga, por isso que ele chora' revidei o comentário dizendo, 'mas o soco foi forte, o rosto não é um lugar que dói?' e ele responde 'não, ele é chorão mesmo, se soubesse brigar não chorava'. De fato, o soco tinha sido forte o suficiente para deixar uma marca no rosto do garoto, e levar o agressor para a diretoria (DC: 11/08/2010). (UCHOGA, 2012, p. 27). 
As entrevistas foram feitas com professores (as) e alunos (as) de turmas de $5^{\mathrm{a}}, 6^{\mathrm{a}}$, $7^{\text {a }}$ séries, em duas escolas distintas. Os roteiros de entrevista docente e discente constam em apêndices assim como a transcrição das respostas. Ambos baseados com que havia sido registrado durante as observações.

Em relação aos alunos, nas entrevistas são indicadas identificações, com sujeitos, local, data e série, além das classificações 'menos participativos', 'mais participativas', 'mais participativos', 'menos participativas'. As questões foram sobre a aprendizagem nas aulas de Educação Física, atividades de preferência, desejos de aprendizagem de outras atividades, participação nas aulas de Educação Física de meninos e meninas e o que mais gostaria da escola. O tempo de duração de cada entrevista é informado como em média de 15 a 20 minutos.

A entrevista com os professores indica data, período final do primeiro bimestre, mas não horário ou tempo de duração, com questões sobre a divisão das turmas no trabalho de diferentes conteúdos, dificuldades, conteúdos mais fáceis e comparações sobre as diferenças entre meninos e meninas nas diferentes séries.

(Professora Júlia): Ah, acho que a maior parte dos conteúdos, independente da proposta, dá para trabalhar junto, sem problema, o que é ruim é muito aluno, mas diferenciar homem, mulher, não! Dá para trabalhar o conteúdo igual, claro que, geralmente os meninos têm mais domínio do que as meninas, até porque os tipos de conteúdo também são muito mais do repertório deles, vamos dizer assim, do que delas. (...). Eu separo na hora do contato físico, que eu tenho mais medo de elas se machucarem, mas também aquela menina que se destaca eu deixo participar, sem problema. (...) é que também depende da classe, às vezes, têm meninos que se comportam super bem, não é um cara estúpido, que empurra, derruba. E tem menina que é mais habilidosa, se jogar com as meninas fica chato para elas (...)" (trecho da entrevista realizada 21/06/2010) (UCHOGA, 2012, p.65) (Grifo da autora).

O documento curricular oficial para a disciplina de Educação Física nas escolas foi analisado e determinante para a execução da pesquisa. A partir dele, com suas proposições de conteúdos e sequências, foram escolhidas as escolas e os professores sujeitos da pesquisa. No primeiro anexo apresenta tabela com os conteúdos da proposta curricular de São Paulo, da $5^{\mathrm{a}}$ série até o $3^{\circ}$ ano do Ensino Médio, por bimestres. 
A análise desse currículo evidencia que ele apresenta uma diversificação dos conteúdos da cultura corporal, sistematizando-os ao longo dos bimestres e séries do ensino fundamental e ensino médio. Assim, entende-se que a implementação desse currículo na rede estadual cria uma possibilidade de que, de alguma maneira, os estudantes das escolas públicas estaduais tenham contato com outros tipos de aprendizagens, além daquelas possibilitadas pelos esportes coletivos (futebol, voleibol, basquetebol e handebol) que frequentemente têm sido mais abordados na disciplina de EF (UCHOGA, 2012, p. 28-29).

A pesquisadora faz constar a elaboração e distribuição de Cadernos do Professor, em 2008, que além dos conteúdos, trariam atividades de aprendizagem e recuperação. Os 'Cadernos do Aluno' foram distribuídos em 2009 para todos os alunos da rede pública estadual de ensino do Estado de São Paulo. Sobre a autoria do material, indica que na “[...] elaboração do currículo, bem como dos Cadernos do Professor, participaram Jocimar Daolio, Luciana Venâncio, Luis Sanchez e Mauro Betti” (UCHOGA, 2012, p. 29).

Oliveira (2010), ao pesquisar alunos que não participam das aulas de Educação Física, procura apresentar, por meio de observações participantes e entrevistas semiestruturadas, um relato sobre alunos e acontecimentos ocorridos na periferia $d a$ quadra. Descreve essa periferia a partir da ideia de pedaço, um espaço, com membros regulares, códigos e comunicação reconhecíveis entre si, de acordo com a Antropologia Urbana de José Guilherme Cantor Magnani.

Apresenta críticas à visão etnocêntrica e aos preconceitos com o diferente com base em (DAUSTER, 1996) e considera a postura de estranhamento pelo pesquisador, uma estratégia para análises com parâmetros que não sejam apenas os de seu próprio sistema de representações e significados de acordo com (VELHO, 1980).

As observações acontecem em uma escola pública, durante seis meses, com uma turma de sétima série, no horário vespertino, com o professor João. A turma tem 25 alunos, com 15 meninos e dez meninas. Foram observadas e apresentadas em forma de quadro, 26 aulas: dez sobre voleibol, oito sobre handebol, uma sobre futebol e outra sobre queimada. Uma das aulas foi destinada para atividades comemorativas de aniversário de uma das alunas. Duas aulas foram sobre avaliação, entrega e comentários dos resultados. Em duas situações de ausências do professor, ele foi substituído em uma aula por outro 
professor da instituição e em outra pelo próprio pesquisador. Ainda foram registradas observações sobre nove ocorrências de aulas livres.

\begin{abstract}
Assim é que a não-diretividade encontrou eco na prática pedagógica do professor João. A ideia de uma aula mais livre, em que os alunos decidissem os rumos das suas aprendizagens, acabava por contemplar o que o professor João intencionava combater, a reprodução irrefletida do esporte profissional nas aulas de EF. Mesmo que seu discurso para os alunos fosse de transformação pedagógica do esporte e suas ações intencionassem não o reproduzir, ao deixar na mão dos alunos a maior parte ou todas as decisões de uma aula, como no caso das aulas livres e das práticas livres, o modelo a ser combatido (esporte profissional) predominava, contribuindo para a existência da 'periferia' da quadra (OLIVEIRA, 2010, p. 125).
\end{abstract}

São estruturados cinco roteiros de entrevista e um questionário aos alunos, todos em apêndice. Nos roteiros dos docentes, duas entrevistas, a primeira em meados de 2009 e outra ao final do mesmo ano letivo. Na primeira, as questões foram relativas ao ano de formação, qual instituição, tempo de magistério, na instituição 'Escolas dos Sonhos' e na turma da sétima série. Foram abordados temas sobre a importância da Educação Física na escola; objetivos, processo de seleção dos conteúdos, avaliação; característica da turma, pontos negativos e positivos; alunos a serem destacados, com justificativa e os significados de ser professor na 'Escola dos Sonhos'. Na segunda entrevista, são tratadas questões sobre a história de vida do professor, os conteúdos desenvolvidos durante o ano de 2009, planejamento coletivo, aulas livres e práticas-livres, gênero e a não participação de alguns alunos.

No roteiro dos alunos para as entrevistas em grupos, realizadas em novembro e dezembro de 2009, as perguntas trataram sobre o tempo em que estudavam juntos, se gostam da escola e por quê, sobre as disciplinas mais importantes e interessantes, a divisão por gênero, as aulas em sala e livres de Educação Física e projeções dos alunos em relação a como deveria ser uma aula de Educação Física.

Nos outros dois roteiros, um destinado à coordenadora pedagógica, as questões foram sobre formação inicial, tempo de atuação no magistério, no cargo que ocupa, de atuação na instituição, sua história na 'Escolas dos Sonhos', conciliação do cargo de coordenadora e professora, visão da instituição e do trabalho realizado em Educação Física. Aos professores de Ciências e Geografia, são replicadas a maioria das questões, com ênfase na especificidade de cada disciplina e na turma do sétimo ano e como os dois 
professores avaliam o trabalho da Educação Física realizado na escola. Com base nas respostas, detecta as motivações para o desentendimento de posições políticas e administrativas na escola entre corpo docente e coordenação,

[...] entendi que o conflito mencionado pela coordenadora Mara, na verdade, era um conflito entre um grupo novo que queria pensar a escola de um modo mais aberto, democrático e participativo na sua gestão, onde se encontravam o professor João e o professor Anselmo, e outro grupo mais antigo da escola que desejava preservar o ideário da Escola dos Sonhos conforme o formato original, quando ainda não era municipalizada, onde se encontrava a coordenadora Mara, a professora Vilma, atual diretora, outras coordenadoras e professoras mais antigas que, inclusive, tinham seus filhos estudando na escola (OLIVEIRA, 2010, p. 89).

Oliveira (2010) não faz referências diretas aos documentos oficiais curriculares nacionais, estaduais ou municipais. O PPP é analisado e traz informações sobre a história da instituição, sua implantação em 1987 como unidade federal e a municipalização em 1998; origem dos recursos financeiros, perfil desejado e concepção do aluno como sujeito de sua aprendizagem. Sobre o Plano de Ação da Escola, refere-se à origem dos alunos em quantidades por município e o dado sobre o ranqueamento da instituição como primeiro lugar no IDEB do Estado de São Paulo.

Apresenta uma detalhada exposição sobre o espaço físico da escola, com imagens de satélite, ilustrações e fotos das salas de aula das disciplinas, de informática, artes, vídeo, música, materiais da Educação Física, Educação Especial, Rádio da Escola, Biblioteca, Administração, pátios externos e interno da escola, cozinha, banheiros, refeitório, miniquadras descobertas e a quadra coberta.

E foi este espaço que se tornou palco privilegiado para o desenvolvimento desta pesquisa, não só por conta da observação das aulas, mas também pelos inúmeros e ricos diálogos tecidos com diversos alunos, não somente com os do $7^{\circ}$ ano, e com o professor João. Foi neste espaço que me tornei um espectador privilegiado não só da 'periferia' da quadra, mas da escola em geral e da Educação Física em específico (OLIVEIRA, 2010, p. 75-76).

As características apresentadas nos seis trabalhos analisados sugerem possibilidades distintas de entendimento sobre procedimentos etnográficos em pesquisas sobre a temática da Educação Física. As articulações produzidas pelos processos de 
observações, entrevistas e análises documentais articulados nos relatórios finais permitem, quando confrontadas com o quadro teórico adotado para esta pesquisa, algumas considerações comparativas que passamos a apresentar.

Entre as características diferenciadoras nos trabalhos ficariam as escolhas sobre os locais para realização da coleta de dados de campo. Na pesquisa de Gramorelli (2007), o campo foi o estabelecimento em sala de aula, com condições de realização de atividades de grupo focal; com Caselli (2012), foram as reuniões de professores e aula observada com a professora de classe, em uma escola particular; cultos e encontros de formação religiosa evangélica constituíram o campo de observações de Rigoni (2008); já as aulas e Educação Física em escolas públicas foram a opção de Oliveira (2010); Uchoga, (2012) e Rocha (2014).

Nos três primeiros trabalhos, um ficou restrito à aplicação de instrumentos de entrevista em grupo; o segundo, à observação de uma aula da professora de classe e o terceiro, às atividades desenvolvidas nos cultos e encontros para formação religiosa. Os pesquisadores apresentam formas de inserção no campo de modos distintos: Gramorelli (2007), por meio de carta convite para participação em reunião com fins de pesquisa; Caselli (2012) se encontrava como profissional da própria instituição, coordenador de área da disciplina de Educação Física; Rigoni (2008) vai a campo em espaços inéditos com sujeitos desconhecidos, na Assembleia de Deus com seus fiéis.

A ideia da efetiva ida a campo, pelo pesquisador, para realização de observações, entrevistas, coleta e análise de documentos que constituiriam a triangulação clássica da etnografia (DEMARTINI, 2009) é denotada quando considerada a importância da articulação entre os pressupostos inicias, os aportes teóricos, metodológicos e os dados obtidos por meio dos instrumentos empregados.

Se para Fonseca (1999) a etnografia seria uma ciência do concreto por excelência, é por esta característica que se determina a necessidade ou condição deste método em se estabelecer a interação direta entre os sujeitos da pesquisa e o pesquisador nos contextos reais de seus acontecimentos, que mesmo possuindo pontos de partida e questões iniciais definidas, terá justamente no contato e estreitamento de relações entre os sujeitos as possibilidades de suas modificações em novas perspectivas de abordagem e problematizações sobre o mesmo objeto.

Na pesquisa de Oliveira (2010), percebem-se mudanças em relação aos critérios de escolha do professor a ter suas aulas observadas, quando mesmo evidenciada a tentativa de diretividade por parte da coordenadora pedagógica, para que o trabalho fosse 
realizado com o Professor João, e não a partir de determinações do pesquisador, este acaba sendo o escolhido para efetivar a pesquisa de campo.

Tal indicação soou, a priori, como um direcionamento do tipo 'vá por aqui que é melhor', o que me fez quase descartar a hipótese de trabalhar com o professor João. No entanto, observando melhor os horários de aula do professor Ricardo, que eram incompatíveis com minha disponibilidade no momento, aliado ao fato de que era seu primeiro ano de atuação na escola, resolvi acatar a indicação da coordenadora, me abrindo assim a fatos não previstos, considerando o pressuposto elucidado por André (1997), a qual afirma que, em etnografia, o pesquisador deve ser flexível no trabalho de campo (OLIVEIRA, 2010, p. 78).

Uchoga (2012), ao partir do questionamento sobre como diferentes conteúdos nas aulas de Educação Física podem influenciar a relação de gênero nas turmas e como a variação pode desestabilizar relações de gênero, já estabelecidas como hegemônicas, de acordo com as práticas corporais desenvolvidas, com o estudo realizado, demonstra que outras categorias, além da variação de conteúdos, também podem atuar nas relações estabelecidas entre alunos e alunas, como a confiança nas próprias habilidades e capacidade de arriscar-se em novas aprendizagens corporais.

A maneira de organizar as aulas mostrou-se como um fator importante para que outros tipos de sociabilidades fossem vivenciados pelos discentes, como em uma das aulas de ginástica artística da escola Hortência, na qual meninos e meninas agruparam-se de acordo com critérios de interesse em cada uma das 'estações' propostas e não pelo gênero e/ou habilidade. Já na escola Sônia, o mesmo conteúdo, porém desenvolvido de maneira mais próxima de sua vertente esportivizada, produziu um grande número de autoexclusões principalmente entre as meninas (UCHOGA, 2012, p.129).

Rocha (2014), ao procurar abordar como se dão as práticas pedagógicas docentes orientadas com base no Currículo do Estado de São Paulo para a Educação Física, detecta nas aulas da professora a aplicação das diretrizes metodológicas constantes no "Caderno do Professor", mas com modificações, adoções e exclusões promovidas em relação ao documento oficial, pautados na experiência da docente, ação de interação denominada pelo pesquisador como currículo alternativo. Porém, entre seus achados, verifica-se ainda uma estratégia de negociação entre professora e alunos, denominada Momento de Livre Escolha de Jogos e Atividades (MLE), uma inflexão de caráter próximo aos de aulas- 
livres (sic), com característica sui-generis, como no exemplo dado sobre a prática de jogo de damas observado de forma participante durante as aulas.

\begin{abstract}
Com relação aos 'jogadores de Damas', havia alguns alunos que sempre optavam por esta prática aos finais das aulas e outros que eram praticamente 'levados' a essa prática pela professora. Sempre que os alunos ficavam 'liberados' para escolher uma das práticas possíveis, um grupo (às vezes pequeno, às vezes grande, dependendo do dia e da classe) optava pela não participação em nenhuma das práticas indicadas. Então, era a vez da professora passar por cada um desses alunos e lhes 'informar' sobre a 'obrigatoriedade' da escolha de alguma atividade. Ela costumava dizer que não era um tempo 'livre para não fazer nada', mas sim um momento para 'a prática de uma atividade livre'. Mesmo assim, por diversas vezes foi possível observar grupos em torno de dois ou mais tabuleiros, movimentando as peças enquanto conversavam. Era uma maneira de burlar a regra da professora e, sempre que esta se aproximava, eles 'atuavam' como se estivessem jogando (ROCHA, 2014, p. 119-120).
\end{abstract}

Especificamente em relação às observações das aulas de Educação Física, todas descrevem inicialmente os procedimentos de busca e definição das escolas e professores. Envolvem processos burocráticos e administrativos entre as instituições de pesquisa e escolares; entrevistas com coordenadores e direção; acertos entre pesquisador e o professor de Educação Física com informações sobre os objetivos da pesquisa, a metodologia empregada, garantias éticas e de anonimato dos participantes, horários para as observações, turmas e datas. Os tempos e períodos passados em campo variam Rocha (2014), 15 semanas, 26 aulas observadas; Uchoga (2012) realiza 128 observações de aula, em três turmas diferentes; em Oliveira (2010), são 26 aulas observadas em seis meses, destas, catorze foram aulas livres ou de práticas livres. Roteiros de observação não são indicados. $^{34}$

Outro aspecto importante, a ser destacado, diz respeito à quantidade de tempo dispendido na realização de pesquisas etnográficas, nas quais, via de regra, enfatiza-se a necessária e prolongada presença do pesquisador em campo, característica diferenciadora das demais pesquisas qualitativas. Diante desta postura é que se vai também possibilitar a alteração das predisposições iniciais do pesquisador, em especial, quando se tratar de pesquisadores que atuam em suas próprias sociedades (BRAGA, 2001).

\footnotetext{
${ }^{34}$ A propósito do conjunto dos seis trabalhos, apenas Caselli (2012) apresenta roteiro para observação da aula e das reuniões de professores.
} 
Sobre o diário de campo elaborado nas pesquisas de Oliveira (2010), Uchoga (2012) e Rocha (2014), de certo modo em contraponto feito a formas de registros realizados nos trabalhos de Gramorelli (2007) e Caselli (2012), entendemos como Caldeira (1988) que a importância de se procurar ser o mais fiel possível às experiências ocorridas em campo através das descrições, cumpre tornar o diário um instrumento fundamental uma vez que

[...] ao escrever e ler seu diário de campo, além de 'esboçar' o outro, 'esboça-se' também como personagem de seu empreendimento já que a forma como esteve imerso naquele conjunto de significados que procura investigar já é, ela mesma, possuidora de múltiplos sentidos, dos quais apenas alguns serão privilegiados na escrita, como resultados dos processos seletivos que o investigador inexoravelmente fará (BRAGA, 2001, p. 211).

Nas entrevistas, as questões dos roteiros são orientadas pela teoria curricular, conteúdos dos documentos oficias e/ou das observações. São transcritas e apresentadas, com respostas em anexo, as pesquisas de Gramorelli (2007), Caselli (2012) e Uchoga (2012); com roteiros, mas sem transcrições das respostas em anexo, Rocha (2014) e Oliveira (2010); gravadas, mas sem especificar roteiro e sem transcrições em anexo, Rigoni (2008). Os sujeitos entrevistados foram professores de Educação Física, professores de outras disciplinas, coordenadores, diretores, membros da comunidade e alunos.

Das pesquisas realizadas com observação de aulas de Educação Física, Rocha (2014) entrevistou apenas a professora do componente, duas vezes e com roteiros diferentes. As outras duas pesquisas (UCHOGA, 2012; OLIVEIRA, 2010), além de entrevistarem os professores, envolveram alunos e membros da comunidade escolar pedagógica e administrativa.

Quatro das pesquisas analisadas apresentam preocupação de melhor compreender as relações estabelecidas entre conteúdos de documentos curriculares oficiais em Educação Física e as práticas pedagógicas escolares desenvolvidas pelos professores da disciplina nas escolas. Como as apropriações são feitas, das diretrizes e orientações curriculares e como procuram desenvolver os princípios pedagógicos e procedimentos metodológicos indicados nos referidos documentos.

Gramorelli (2007) com os PCNs, documento oficial federal; Rocha (2014) e Uchoga (2012), a PCSP-EF, que são as orientações curriculares oficiais para a rede 
pública estadual do Estado de São Paulo e Caselli (2012) sobre o PYP. Rigonni (2008) e Oliveira (2010) fazem menções a documentos curriculares, mas não os utilizam com referencial para as análises sobre os dados obtidos em campo.

Diversos documentos sobre legislação e currículo são apresentados: Caselli (2012) menciona o documento básico do Exame Nacional do Ensino Médio (ENEM) (BRASIL, 1999); e os Parâmetros Curriculares Nacionais: Educação Física - terceiro e quarto ciclos (BRASIL, 1998). Rocha (2014) e Uchoga (2012) citam o Decreto Lei Federal n. 3.199, de 14 de abril de 1941, a Proposta Curricular do Estado de São Paulo: Educação Física (SÃO PAULO, 2008a); os Cadernos do professor: educação física (SÃO PAULO, 2008b) e, finalmente, Oliveira (2010) cita o Decreto Federal $n^{\circ} 69.450$, de $1^{\circ}$ de novembro de 1971 e a Lei $n^{\circ}$ 9394/96 de 20 de dezembro de 1996, que estabelece as diretrizes e bases da educação nacional.

Gramorelli (2007) apresenta extensa lista de documentos consultados e analisados, desde a Constituição (1988), o Decreto Federal n ${ }^{0} 69.450$, de $1^{\circ}$ de novembro de 1971 e a Lei n ${ }^{\circ}$ 9394/96 de 20 de dezembro de 1996, e as Leis 5.692/71 e 9131/95, até os Parâmetros Curriculares Nacionais do primeiro, segundo, terceiro e quarto ciclos do Ensino Fundamental; da Educação Infantil; do Ensino Médio e suas Orientações Complementares.

[...] teve a intenção de elaborar algumas reflexões acerca do contexto de produção dos 'Parâmetros Curriculares Nacionais', documentos oficiais propostos pelo Ministério de Educação e Cultura do governo federal, publicados a partir de 1997. Para o enriquecimento desta análise, foi necessário recuperarmos para o debate o momento sociopolítico e histórico no qual os documentos foram elaborados e publicados, como também, conhecer quais as principais questões apontadas por intelectuais no campo educativo (GRAMORELLI, 2007, p. 05).

O minucioso trabalho de levantamento de fontes teóricas, legais e curriculares realizado, cronologicamente apresentados, historicamente situados, dando suportes no desenvolvimento e análises das atividades do 'Grupo Focal' confirmam a relevância que as análises documentais de documentos oficiais possuem para pesquisas em Educação, assim como para os processos de organização do trabalho pedagógico dos professores de Educação Física. 
Neira (2011a) denota importância à relação entre as práticas pedagógicas dos professores de Educação Física, em seus planos de aula, com os objetivos educacionais mais amplos, expressos institucionalmente por meio de documentos como currículos oficiais e os projetos políticos pedagógicos das escolas. Ao se referir sobre a atuação dos professores, sujeitos em sua pesquisa sobre o 'Currículo Cultural em Educação Física' colocado em ação, apresenta a relação destes professores com o princípio pedagógico de articulação com os objetivos educacionais das intuições educativas,

Percebe-se que os professores parceiros não trabalham às cegas, tampouco desenvolveram seu trabalho por conta e risco. Na esperança de que a escola acompanhasse a proposta curricular oficial, buscaram apoio no documento municipal que fornece orientações para a organização da prática pedagógica, o que não deixa de ser um sinal de preocupação com a execução coletiva da tarefa educacional (NEIRA, 2011a, p. 84).

Molina Neto (1999), ao abordar o tema da etnografia como opção metodológica para pesquisas em Educação Física, refere-se a uma 'etnografia crítica', que ao mesmo tempo em que aumenta a produção de conhecimentos sobre determinado grupo e sua cultura, descobre, também, as situações de injustiça e opressão a que todos estariam submetidos. A observação participante é apresentada como de grande complexidade, em que teria, de acordo com Anguera Arguila (1995), “[...] a vantagem de facilitar o estudo social e o acesso à informação restringida e, em troca, tem como inconvenientes a interferência maximizada da subjetividade do observador e do observado" (MOLINA NETO, 1999, p. 126).

Como proposta analítica do tipo de etnografia que procura realizar, situa as reflexões no campo teórico das tradições críticas, dialéticas, orientadas pelos movimentos teoria-prática, fato-reflexão, objetividade-subjetividade, em que todos estão inseridos em contextos mais amplos, entre o ser e o dever ser, e que na “[...] interação desenvolvida pela atividade investigadora, investigador, investigado ensinam, um ao outro, por meio de signos, aprendizado da realidade que lhes circunda e nas expectativas de como gostaria que ela fosse” (MOLINA NETO, 1999, p. 116).

Apresentado como verbete, no Dicionário Crítico de Educação Física, o mesmo autor Molina Neto (2005), sobre etnografia, destaca seu caráter qualitativo e hermenêutico, a compreensão do outro em seu contexto cultural, em seus significados próprios atribuídos. Estuda as relações humanas, a compreensão dos fenômenos em sua 
essência, com a descrição, interpretação e representação que os grupos e sujeitos dão na cotidianidade de suas vidas.

[...] requerem, contudo, um considerável tempo de permanência nas comunidades estudadas e a prioridade da análise centrada na perspectiva dos atores do drama sociocultural. É o caráter reflexivo do pesquisado e sua atitude vigilante aos eventos e às rotinas das pautas sociais que oferecem, do mesmo modo, riqueza e dificuldades à etnografia, posto que etapas como construção do problema de investigação, o trabalho de campo e a análise e interpretação das informações que são demarcadas em outros modelos de pesquisa, nela se realizam muitas vezes de forma simultânea, flexível, descontínua e interpenetrada, requerendo do investigador muito mais do que a simples aplicação de técnicas de construção da informação, ou de um protocolo definido apriori. Exige do pesquisador grande capacidade de reflexão, compromissos éticos com os participantes, relativização cultural, além de perseverança e criatividade ao processo investigado (MOLINA NETO, 2005, p. 292).

Diante disso, as indicações feitas no resumo e corroboradas nas análises metodológicas feitas na pesquisa de Gramorelli (2007), pela ausência de observação participante, assumida como 'investigação etnográfica' e em Caselli 2012, com apenas uma aula observada, da professora de classe, denominada 'estudo do caso etnográfico', remetem-nos às críticas de Magnani (2001), que entende que em algumas pesquisas a identificação metodológica etnográfica venha se constituir mais como um rótulo do que propriamente um instrumento real de trabalho, nas quais apenas umas breves aproximações junto aos sujeitos da pesquisa não seriam suficientes para identificá-las substantivamente como etnográficas.

Nas pesquisas de Rigoni (2008) e Oliveira (2010), denominadas como 'etnografias'; em Uchoga (2012) como do ‘tipo etnográfica’ e em Rocha, (2014), um 'estudo do caso etnográfico', encontram-se estruturas de atuação planejadas para efetiva realização de trabalho em campo, com coleta de dados por observação participante, que como indicadas por Braga (2001), seria da revisão da literatura sobre o tema aliada ao trabalho empírico, de modo processual, que se vai, portanto, reconstruindo e reelaborando os propósitos inicias da investigação, ou ainda, como expresso por Rockwell (2009) sobre o papel do pesquisador a ser desempenhado em campo, este deve "[...] acercar-se personalmente a sus viscitudes de la vida cotidiana y a los significados que los hechos tienen para los habitantes del local" (p. 186). 
Em relação a aspectos específicos da teoria curricular e aos documentos de referência adotados pelos autores, Gramorelli (2007), ao se referir ao discurso neoliberal em Educação, pontua como este efetua uma crítica ao funcionamento do Estado e de como sua ineficiência traria dificuldades para o sistema educacional, no qual a crise instalada na área, conforme as premissas neoliberais, não seria de "[...] democratização, mas uma crise de gestão, pois o sistema é mal administrado, e isso é o que possibilita o alto índice de analfabetismo funcional, evasão escolar e repetência” (p. 24).

Ao identificar de acordo com Gentili (1996), que no processo de construção de sua hegemonia, o neoliberalismo necessita produzir significados no âmbito da cultura que ratifiquem as alterações sociais julgadas necessárias, destaca que entre as estratégias de convencimento ideológico está o estabelecimento da centralidade do conceito de "qualidade", de caráter restrito empresarial, mas que transferido diretamente para o campo educacional busca determinar que "[...] as instituições de ensino devem ter seus resultados julgados, e, para isso, eles precisam ser avaliados. É necessário saber se elas são empresas produtivas, pois o receituário neoliberal possui um conceito próprio e específico de qualidade" (GRAMORELLI, 2007, p.25).

A pesquisadora delineia o cenário em que foi possível o estabelecimento das teorias críticas em Educação Física, com a qualificação em programas de pós-graduação dos professores de Educação Física, orientados nos referenciais das ciências humanas nas décadas de 70 e 80, com origem em críticas feitas aos paradigmas da aptidão física e dos esportes sobre os marcos do capitalismo.

Toda essa discussão possibilitou o aparecimento das teorias críticas de currículo tanto na Educação quanto na Educação Física, como é o caso da abordagem Crítico-superadora, que se baseia fundamentalmente, segundo Bracht (1999, p.79), na pedagogia Histórico Crítica Social dos Conteúdos, formulada por Dermeval Saviani e José Carlos Libâneo, estando consubstanciada no livro "Metodologia do Ensino de Educação Física", de um coletivo de autores publicados em 1992 (GRAMORELLI, 2007, p. 24).

A abordagem curricular crítico-superadora em Educação Física Escolar, orientada pelos pressupostos teóricos da Pedagogia Histórico-crítica compreende que os temas da cultura corporal não se reduzem à apropriação de conhecimentos sobre o gestual técnico e instrumental dos esportes, danças, lutas e ginásticas. A abrangência dos conteúdos, em face às mais diferentes apresentações, em sociedade da cultura corporal, permitem 
indicações em termos pedagógicos de que possam ser explorados aspectos históricos e contemporâneos, referentes a problematizações do mundo do trabalho e do lazer nas sociedades capitalistas.

Como indicado no quadro curricular "Crítico-superador" em seu segundo elemento, relaciona-se a fase de problematização como momento de detecção de questões e conhecimentos necessários a resoluções, o fio-condutor de todo o processo de ensinoaprendizagem, ainda que preparatório no sentido de que “[...] o educando, após ter sido desafiado, provocado, despertado e ter apresentado algumas hipóteses de encaminhamento, compromete-se teórica e praticamente com a busca da solução para as questões levantadas. O conteúdo começa a ser seu" (REIS et al. 2013, p. 60).

Ganha assim importância, junto à participação e compreensão da execução técnica dos movimentos, as análises e reflexões críticas sobre os processos de acesso, exploração e socialização das práticas e conhecimentos sobre a cultura corporal, denunciadas em ponto de partida, como desiguais, injustas e de forte apelo ideológico na sociedade de mercado e capitais.

Gramorelli (2007) identifica o conceito de cultura corporal de modo destacado nos documentos e considera que os PCN podem ser compreendidos do modo como Neira e Nunes (2006) os classificam, como que alinhados às perspectivas críticas de currículo, mesmo que apresentando variações ou até contradições entre os documentos referentes ao Ensino Fundamental e Médio.

\footnotetext{
Segundo o que apresentamos no texto, podemos dizer que os Parâmetros Curriculares Nacionais se fundamentam na proposição das teorias críticas de currículo, por entenderem que a tematização dos elementos incluídos na cultura corporal - os jogos, as danças, as lutas, as ginásticas, os esportes - e sua historicização, possibilita a elaboração de um currículo que favorece a construção de conhecimentos dos alunos no sentido de problematizar, dialogar e transformar a sociedade na qual estão inseridos, ratificando assim a inclusão dessa concepção nas teorias críticas (GRAMORELLI, 2007, p.24).
}

Quanto aos elementos da cultura corporal, são mais citados os jogos, as lutas e os esportes. As ginásticas e atividades rítmicas são listadas, mas menos enfatizadas pelos professores. O esporte aparece ainda como destaque, porém “[...] quando os professores apresentaram exemplos de trabalhos com o tema esportes, estes não possuíam 
características de prioridade sobre desempenho e rendimento físico" (GRAMORELLI, 2007, p.103).

Rocha (2014), sobre as apropriações feitas pelos professores em relação aos conteúdos da PCE-SP, entende que sejam notáveis as modificações dos procedimentos em aula, a partir das interpretações dadas pela professora aos materiais curriculares e de apoio, quando consideradas também as suas experiências cotidianas de sala de aula. Os saberes experienciais, como efeito das retomadas críticas, realizadas pelo professor, em que relações de exterioridade com os conhecimentos científicos, profissionais, pedagógicos são efetivamente interiorizadas pela prática docente, constituindo-se, assim, como uma 'alternativa curricular', que reúne elementos do currículo oficial e formação acadêmica do professor, mas que podem ser ajustados, preteridos, modificados de acordo com o contexto e suas especificidades.

As orientações curriculares foram rejeitadas ou incorporadas à prática da professora Lolla, dependendo de sua relevância diante das situações concretas de aula, suas próprias crenças e disposições acerca da disciplina, por um processo em que ela elimina aquilo que não parece se adequar às condições concretas do seu contexto e conserva o que se mostra útil para sua ação docente (TARDIF, 2008). Ao assumir certas convicções para suas aulas de Educação Física, a professora optou por uma ou outra ação nas aulas, um ou outro discurso (justificativa), que passaram a fazer sentido no momento em que foram relacionados aos saberes e experiências, percebidos em suas ações e discursos ao longo do estudo (ROCHA, 2014, p. 167).

A Educação Física, como disciplina curricular obrigatória nos Ensinos Fundamental e Médio, articulada aos projetos políticos pedagógicos das escolas, constitui-se como um momento privilegiado para vivências e discussões sobre as mais diversas questões que dizem respeito ao corpo em sociedade, tomando como referências para os conteúdos, temas ligados às brincadeiras, esportes, danças, lutas e ginásticas. As abordagens podem se dar em relação às condições históricas, físicas, materiais, profissionais, técnicas, econômicas e políticas que proporcionariam o surgimento, a existência e a realização de determinadas atividades corporais, até mesmo em detrimento de outras. 
A agenda de debates em torno da definição dos conhecimentos que devem fazer parte do currículo, particularmente no caso da Educação Física, vive um momento de grande ebulição. O que um determinado grupo considera conteúdo legítimo e necessário para ser ensinado e compor a formação dos sujeitos da educação, noutro momento histórico talvez seja retirado. O conteúdo suprimido torna-se desnecessário e esquecido, sendo substituído por outro considerado relevante. O exercício de tiro, por exemplo, fez parte das aulas de Educação Física no currículo ginástico. Em tempos de guerras e revoltas, da aplicação dos métodos ginásticos e da influência das concepções militaristas na educação, sem dúvida, o tiro foi considerado adequado à formação dos valores da época (NEIRA, 2011a, p. 126).

Rocha (2014), ao contestar os momentos de não diretividade detectados nos desenvolvimentos das aulas da professora Lolla, na segunda parte do período das aulas duplas de Educação Física, denominado por ela mesma como 'Momento de Livre Escolha de Jogos e Atividades' (MLE), afirma que este procedimento reduz o componente à esfera da prática, simplificando-o como mera atividade de fruição, produz consequências negativas para a formação dos alunos, com a detecção contraditória de seu suposto caráter libertador.

A partir de Snyders (2005), a ideia de obrigatoriedade, na qual me apoio, vê, na obrigação imposta pela escola, a chance de o aluno poder encaminhar-se para algo que a princípio não o atraía, chance esta que não existiria espontaneamente. Segundo este autor, 'As obrigações da escola podem levar os alunos a uma independência que torna quase insignificante a liberdade que eles pensam encontrar quando fazem muito simplesmente tudo de que têm vontade na hora' (p.114). Trazido para as aulas de Educação Física, pode-se considerar que a obrigatoriedade de participarem das aulas em todos os seus momentos (todas as suas dimensões) seja um ato libertador das limitações impostas pelos próprios alunos, quando se negam a participar mais ativamente (ROCHA, 2014, p. 172).

Na postura híbrida, alternativa, em relação ao currículo oficial, nos procedimentos didáticos, observados das aulas de Educação Física da professora Lolla, relatados por Rocha (2014), denota-se a importância do reconhecimento dos diversos saberes sobre a cultura corporal, apresentados na comunidade escolar, especialmente os que procuram expressar manifestações não hegemônicas, em contraposição aos temas e conteúdos tradicionalmente ligados à disciplina e comumente ratificados pelos currículos oficiais. 
Sobre aspectos curriculares, além das referências ao currículo oficial, institucional, Caselli (2012) dialoga com as teorizações curriculares de Silva (2000) e Moreira (2002), que criticam programas de educação internacionalistas ou multiculturais nos quais as diferenças são reconhecidas como algo a ser tolerado - como uma benevolência de quem tolera; respeitadas em si; em harmoniosas convivências, sem que se problematizem, permanentemente, as relações de poder, produtoras das diferenças e das desigualdades.

\begin{abstract}
Neira e Nunes (2009 p. 57) reiteram a ideia de que '[...] o currículo contribui para moldar as pessoas de forma a construir os cidadãos almejados pelo projeto social' além de identificar a responsabilidade do currículo na '[...] promoção da socialização das crianças e jovens de uma sociedade em acordo com os valores tidos como desejáveis'. Para Silva (2000), Neira e Nunes (2009), o currículo atua ideologicamente na medida em que busca intervir na maneira de ser, aprender, sentir e agir dos alunos (as), o que denota um caráter controlador de qualquer currículo que se configura a partir da busca de formar um perfil de sujeito (CASELLI, 2012, p.84-85).
\end{abstract}

As relações de poder e a produção de ideologia são discutidas tanto pelas teorias críticas quanto pelas teorias pós-críticas em Educação. Para a pedagogia histórico-crítica, os debates se centralizam nas contradições estabelecidas nas relações de poder entre a burguesia e o proletariado, a ideologia é entendida como falsa consciência, em uma realidade social de exploração dos trabalhadores e de sua alienação pela indústria cultural.

Nos currículos pós-críticos, a concepção é a de que o poder se encontra completamente espraiado na sociedade nas relações entre os sujeitos, em constante circulação e em condições de provisoriedade, por essa mobilidade, as análises da ideologia recaem então sobre dúvidas a respeito de se ser exequível ou mesmo desejável, em definitivo, o estabelecimento de noções de verdades.

As teorias pós-críticas ampliaram as análises das teorias críticas, fortaleceram a resistência aos ditames da sociedade classista e alertaram que as relações de poder operam também por meio de outros marcadores sociais: etnia, gênero, religião, tempo de escolarização, local de moradia, etc (NEIRA, 2011a, p. 52).

Em Rigoni (2008), a Educação Física entendida como componente curricular obrigatório que, por suas especificidades, irá constantemente se deparar com questões em 
relação ao corpo religioso que entra na escola, com suas técnicas corporais, significados, simbolismos, condições de gênero, com sua formação orientada formalmente e reforçada pela convivência em grupo e familiar.

Penso que a Educação Física tradicional não dá conta de compreender esta diversidade social que gera também a diversidade das técnicas corporais presentes nos alunos. Partindo desta consideração, certos autores da Educação Física, vinculados às Ciências Humanas, iniciaram uma discussão praticamente ignorada pela área, que até então estava voltada somente para os conteúdos vindos da medicina e da educação militarista. Com isso, começa-se a pensar na aula de Educação Física como o lugar privilegiado do 'se movimentar', mas não o se movimentar com objetivos de treinamento físico, performance, desenvolvimento e aprendizagem motora. Começa-se a pensar em 'gestos', ou seja, em movimentos dotados de significados e de sentidos que fazem parte da cultura de movimento de um determinado grupo social. Neste sentido, temos autores como Jocimar Daolio, Valter Bracht, Elenor Kunz, Mauro Betti e outros que entendem a aula de Educação Física a partir do viés das Ciências Humanas. Estudos pautados nestes conceitos dialogam melhor com as questões da diversidade cultural (RIGONI, 2008, p.143-144).

$\mathrm{Na}$ vertente curricular pós-crítica, Neira (2011a) destaca a "justiça curricular", compreendida como um dos alicerces do edifício curricular cultural da Educação Física; nele identifica o modo singular de como as práticas educativas devem assumir como legítimas todas as manifestações da cultura corporal presentes internamente na comunidade escolar e seus arredores, sendo assim "[...] um aspecto primordial do processo de escolarização com vistas à construção de identidades democráticas, por priorizar o questionamento da forma com que são construídas as representações do outro, do diferente" (NEIRA, 2011a, p. 100).

Sobre a diversidade cultural existente nas escolas e comunidade e a possiblidade de captá-la no sentido de que possa fornecer elementos para os encaminhamentos das práticas pedagógicas culturalmente orientadas, o procedimento didático de mapeamento é indicado como ação que visa identificar as apreensões que os alunos possuem a respeito de suas próprias práticas corporais com finalidade de ressignificá-las. 
$\mathrm{O}$ olhar atento às culturas que orbitam no universo escolar é a característica mais marcante do mapeamento. As informações recolhidas com os alunos constituem elementos fundamentais para dimensionar o tema de estudo e as possibilidades que esse estudo apresenta para o desenvolvimento das aulas. Informações, que sem dúvida, minimizam a incidência de improvisos e uma eventual descaracterização das atividades de ensino previamente elaboradas (NEIRA, 2011b. p.112).

Observe-se que a noção de mapeamento diverge dos processos de elaboração de práticas pedagógicas de matriz histórico-crítica. Gasparin (2007), ao se referir à 'Prática Social Inicial', considera como tarefa primeira do professor realizar um levantamento sobre o que os alunos já sabem em relação aos conteúdos, individualmente, mas, sobretudo coletivamente, em que as expressões dos saberes do grupo devem ser compreendidas como manifestações condicionadas por outras referências mais abrangentes em sociedade, seria o momento em que o "[...] professor toma conhecimento do ponto de onde deve iniciar sua ação e o que falta ao aluno para chegar ao nível superior, expresso pelos objetivos, os quais indicam a meta ser atingida" (GASPARIN, 2007, p.2324).

Para Uchoga (2012), a análise do documento curricular oficial do Estado de São Paulo para a disciplina de Educação Física nas escolas foi determinante para a execução da pesquisa. A partir dele, com suas proposições de conteúdos e sequências, foram escolhidas as escolas e os professores sujeitos da pesquisa.

\begin{abstract}
A análise desse currículo evidencia que ele apresenta uma diversificação dos conteúdos da cultura corporal, sistematizando-os ao longo dos bimestres e séries do ensino fundamental e ensino médio. Assim, entende-se que a implementação desse currículo na rede estadual cria uma possibilidade de que, de alguma maneira, os estudantes das escolas públicas estaduais tenham contato com outros tipos de aprendizagens, além daquelas possibilitadas pelos esportes coletivos (futebol, voleibol, basquetebol e handebol) que frequentemente têm sido mais abordados na disciplina de Educação Física (UCHOGA, 2012, p. 28-29).
\end{abstract}

Neira (2015), no entanto, apresenta críticas em relação ao modo como o documento foi elaborado, pois este não apresentaria critérios para a reunião dos conteúdos por temas ou para a eleição das modalidades esportivas indicadas sequencialmente por bimestre; são apresentadas abordagens simplistas para temas complexos. Faz o registro 
de que o documento expressa a objetiva intenção de fixar significados únicos para cada conteúdo trabalhado.

A fixação dos significados é ainda mais contundente no tema "Organismo humano, movimento e saúde", quando o único estilo de vida aceito é o baseado na prática sistemática da atividade física, acompanhada de uma alimentação "saudável", retomando alguns dos princípios básicos da educação para a saúde (GUEDES, 1999), apesar de a fundamentação apoiar-se na perspectiva crítico-emancipatória (KUNZ, 1994) (p. 247).

Neste sentido, Neira (2015), sem concepção metodológica para o trato dos conteúdos, tem na abordagem descritiva sequencial, detalhada dos cadernos didáticos, a evidência de seu caráter principal prescritivo. Desconsiderando quase que completamente os marcadores sociais contidos nas práticas corporais historicamente, também não apresenta concepção avaliativa para além de questões sugeridas sobre aspectos a serem observados e sua instrumentalização.

Apesar do consenso existente na área a respeito do entendimento de cultura corporal como produção distintiva dos grupos que coabitam a sociedade, os documentos analisados privilegiam a tradição euroamericana, em detrimento das brincadeiras, danças, lutas, ginástica e esportes (ou dos significados a eles atribuídos) disseminados pelos grupos minoritários. O que dizer então da falta de menção à avaliação ou de orientações didáticas em algumas propostas? (p.250).

Uchoga (2012) apresenta em suas análises que, junto à Proposta Curricular do Estado de São Paulo, estão os "Cadernos do Professor" e dos alunos, com a lista de conteúdos a serem trabalhados, assim como atividades de aprendizagem e recuperação. Trazem exemplos de ações didáticas, com atividades voltadas à concepção da cultura corporal como objeto de estudo da Educação Física, com sua inserção demarcada na área das Linguagens.

Neira (2011c), ao analisar os conteúdos sugeridos pela proposta curricular de Educação Física da SEE/SP descritos nos 'Cadernos do Professor' aponta o modo superficial, fragmentado, com características informativas e instrumentais com que os conhecimentos são apresentados. Uma vez fornecidos, listados e distribuídos bimestralmente os conteúdos, a tarefa do professor seria a de criar condições adequadas para sua apropriação, não importando se os alunos se encontram em escolas das regiões 
urbanas centrais ou periféricas, em localizações rurais ou litorâneas. Com todos devendo aprender o mesmo e da mesma forma, sejam quais forem as circunstâncias. O viés conformista do documento é apontado quando não são detectados indicativos sobre as características multiculturais e democráticas da sociedade atual em suas implicações e desafios para a escola, entendida como espaço público com determinações devendo ser orientadas pela equidade, direitos, justiça social, cidadania e espaço público.

Dentre as omissões, talvez, as mais contundentes sejam a falta de temas controversos e fontes de informação que consideram os conflitos a partir de perspectivas alternativas e divergentes. As situações de aprendizagem propostas simplesmente não consideram essa possibilidade (NEIRA, 2011c, p. 26).

Neira (2011c) também afirma que deve ser entendida como uma proposta de caráter assimilacionista, em que as diferenças são rigorosamente apagadas, com alunos e alunas em todas as escolas reagindo igualmente, por exemplo, aos conteúdos como ginástica rítmica desportiva, capoeira e hip-hop, independentemente de questões ligadas ao gênero, religião, classe e outros marcadores sociais.

De qualquer modo, Uchoga (2012), ao tomar como referência principal o próprio documento curricular estadual de SP, mais os Cadernos do Professor e do Aluno, considera que ao encontrar, na sistematização dos conteúdos por séries e na sua diversificação, meios para propor análises sobre a participação de meninos e meninas nas aulas de Educação Física.

O próprio professor relata que em um levantamento feito por ele, os discentes não haviam aprendido sobre qualquer tipo da ginástica nas aulas de Educação Física dos anos anteriores, mesmo a $6^{\mathrm{a}}$ série, que teoricamente deveria ter tido contato com esse conteúdo, não o teve, isso porque os professores temporários que haviam passado na escola no ano anterior não abordaram os conteúdos da proposta curricular. Esses dois pontos estão expressos nas falas de Kéren e Vinicius, que, ao serem questionados sobre as atividades que mais haviam gostado e o porquê, respondem: "Ginástica. Ah, eu acho que é um pouco mais fácil e todo mundo sabe fazer, entendeu? Já basquete tem pessoa que não sabe brincar, aí ginástica é mais fácil e todo mundo brinca junto" (Kéren) e também 'Eu gostei de ginástica, eu achei diferente, porque a gente não tinha feito né!' (Vinícius) (UCHOGA, 2012, p. 117). 
Sobre a diversificação de conteúdos indicada no documento oficial, é conferida especial relevância pelo fato de influenciar as formas de participação dos meninos e meninas nas aulas de Educação Física, pois foi de acordo com cada conteúdo trabalhado nas aulas que teria sido possível descrever quem, dos alunos e alunas, e de quais modos, em suas diferenças, participavam.

Neira (2011a), ao se remeter às contribuições do currículo cultural, refere-se à maneira do trato das atividades de ensino nas aulas de Educação Física por meio de temas, compreendidos como as efetivas práticas sociais de determinadas manifestações corporais, em detrimento de abordagens cuja centralidade recai nos conteúdos e objetivos pré-estabelecidos. Como exemplo, oferece a forma como os professores-parceiros de sua pesquisa realizam a tematização em suas aulas em que

[...] emaranharam as próprias culturas corporais experienciais e as dos alunos, com outros saberes (acadêmico, do senso comum, populares ou pertencentes a outros grupos). No bojo dessa triangulação, obtiveram a produção de novos sentidos para as manifestações corporais tematizadas (NEIRA, 2011a, p.126).

Oliveira (2010) identifica a Educação Física como componente curricular da educação básica, que tem nas abordagens didático-metodológicas sobre a cultura corporal, sua especificidade. Demonstra algumas das origens de cristalizações na disciplina que permitem a hegemonia do esporte como principal conteúdo das aulas de Educação Física, pela implementação de metodologias oficias, legislação, espaços físicos e materiais específicos.

'Formação Integral do Homem' e 'Socialização do Aluno' são duas expressões criticadas como argumentos frágeis que pairam como justificativas legitimadoras da disciplina na escola e na sociedade. A disciplina como auxiliar, contributiva da aprendizagem de outras disciplinas seria um outro argumento na mesma direção de precariedade.

Assim, sustento a diretividade como forma de superação do fenômeno da 'periferia' da quadra. Nesse estudo, os alunos demonstraram querer participar do processo pedagógico, mas não com total e absoluta liberdade, muito menos como vozes inferiorizadas. Quiseram aprender, ansiaram por isso, mas tiveram poucas possibilidades. Reafirmando o elucidado no capítulo anterior, não se pode esperar que o desejo dos alunos se emparelhe com os objetivos dos programas escolares. Mas 
também não se pode descartá-los, entendendo-os como menos válidos, é preciso afiná-los, a fim de que estes se ampliem na direção da satisfação em aprender (OLIVEIRA, 2010, p. 179).

No componente denominado instrumentalização do currículo Crítico-superador da Educação Física, é identificado o momento em que o conhecimento deva ser apropriado, aplicado e transformado pelo aluno. Gasparin (2005) e Saviani (2006) consideram que é a apropriação dos conhecimentos sistematizados historicamente que permite melhores condições para os enfrentamentos políticos necessários em sociedades marcadamente desiguais e injustas, sendo assim,

[...] ferramentas culturais necessárias à luta social que travam diariamente para se libertar das condições de opressão em que vivem; ou seja, trata-se da fase na qual ocorre a apropriação dos instrumentos teóricos e práticos necessários ao equacionamento dos problemas detectados na prática social (REIS et al, 2013, p.60).

Ao tomar-se a catarse como momento avaliativo sobre o qual são realizadas atividades de demonstração teórica, como a expressão material do conhecimento, elevado a um novo patamar de entendimento (SAVIANI, 2006), compreende-se que de acordo com referencial das teorias críticas em Educação não se pode prescindir da diretividade no processo de desenvolvimento das aulas. O trato dos conteúdos de forma sistematizada é que direcionaria as práticas pedagógicas de modo que se possa auferir em que medida os conhecimentos foram ampliados, transformados em suas acepções iniciais.

As análises curriculares, aqui realizadas, constituem-se como um momento para estabelecimento de relações entre os elementos teóricos dos Currículos Crítico-superador e Cultural em Educação Física, com aspectos mais específicos sobre os diferentes modos de entendimento e apreensões sobre currículo apresentado pelos pesquisadores.

Ao iniciar esta pesquisa, tinha-se a hipótese de que além das características etnográficas nos trabalhos analisados, questões relativas às teorias curriculares pudessem ser também alvo de reflexões, numa tentativa de correlação direta entre os pressupostos teórico-metodológicos e as etnografias escolares encontradas.

No entanto, nas pesquisas delimitadas para a análise, não foram encontradas correlações explícitas entre as matrizes curriculares Crítico-superadoras e a Cultural, com ressalva feita a Gramorelli (2007) que se refere às origens das influências das teorias críticas em educação e educação física, a partir dos anos 1980. 
Todavia um esforço foi feito de identificar problematizações curriculares nas pesquisas, estabelecer nexos com as matrizes curriculares referenciais adotadas, no sentido de ampliar reflexões sobre as práticas pedagógicas escolares em Educação Física de acordo com os dados coletados nas pesquisas, tornadas objeto desta investigação.

Deste modo, com Caselli (2012), a implementação didática pelos professores de Educação Física do PYP e a produção das diferenças e desigualdades pelo currículo; Rocha (2014), com as apropriações feitas ao currículo oficial pela professora Lolla e a alternativa curricular detectada; Uchoga (2012) sobre a participação dos alunos e alunas da Educação Física e a diversificação de conteúdos; Oliveira (2010), com os alunosalunas que não participam das aulas e a obrigatoriedade disciplinar; Rigoni (2008) sobre a constituição da gestualidade dos corpos evangélicos, em suas implicações para as aulas de Educação Física, foram articuladasas discussões sobre relações de poder e ideologia; diversidade cultural e de conteúdos; problematização e tematização; justiça curricular; prática social inicial; instrumentalização; avaliação e catarse. 


\section{CONSIDERAÇÕES FINAIS.}

Este trabalho teve como objeto a Educação Física Escolar em pesquisas sobre o fazer pedagógico. A escolha por dissertações e teses etnográficas deu-se em função da hipótese de que este tipo de pesquisa, pela proximidade estabelecida entre os pesquisadores e sujeitos nos espaços escolares, pudesse trazer elementos significativos tanto em relação aos modos como são produzidas essas etnografias na escola, quanto referentes à identificação de aspectos curriculares da disciplina em suas práticas pedagógicas.

Durante o percurso de levantamento de pesquisas caracterizadas como etnografias escolares em Educação Física que, originalmente tinha por objetivo a constituição de banco de dados com dissertações e teses, de âmbito nacional, foram consideradas as limitações de atualização do banco de pesquisas disponível pela CAPES. Neste sentido, portanto, restringiu-se o levantamento do material empírico à produção dos programas de pós-graduação em Educação e Educação Física das universidades estaduais paulistas, USP, UNICAMP e UNESP.

Às dificuldades encontradas em relação ao levantamento de fontes com pesquisas etnográficas escolares em Educação Física de ordem técnica, são acrescentados aspectos quantitativos da própria produção escolar em geral da área. Bracht et al. (2012), em levantamento sobre a produção de conhecimento em Educação Física Escolar nos periódicos brasileiros, no período de 1980-2010, constata que dos 4.166 artigos publicados, em nove revistas científicas da área, 647 teriam como tema central a Educação Física Escolar, aproximadamente $15.5 \%$ do produzido, sendo apenas 225 trabalhos compreendidos como de intervenção, específicos sobre a ação pedagógica nas aulas.

Não só esse dado é preocupante em relação ao futuro (e ao presente) da Educação Física Escolar no campo acadêmico da Educação Física. Betti et al. (2011) identificaram que dos 710 periódicos nacionais enumerados na área 21 (Qualis CAPES), apenas 28 deles apresentavam na sua política editorial espaço para a subárea da Educação Física Escolar. Além disso, citam a pesquisa de doutorado de Nascimento (2010) que, analisando as 333 teses de doutorado produzidas nos programas da área, entre 1994 e 2008, em seis universidades, constatou que apenas 6,3\% dessas tinham a Educação Física Escolar como temática, variando de zero teses (USP, UNESP/Rio Claro e UCB) a 16 teses (UNICAMP) (BRACHT et al., 2012, p. 19). 
De acordo com os objetivos estabelecidos para este estudo, o processo de analisar pesquisas etnográficas permitiu acentuar a relevância do pesquisador em campo, com uma posição assumida de observador participante que, no contato direto com os sujeitos e no ambiente em que se dão os acontecimentos das aulas, imprime pela proximidade estabelecida, constantes possibilidades dialógicas de reorientação das questões iniciais metodológicas e pedagógicas, assim como de aprofundamento sobre temas emersos da experiência de campo.

Genericamente, pode-se falar de um consenso expresso nos textos sobre o fato de que a pesquisa etnográfica é iniciada de forma aberta, aceitando-se que recortes ou ajustes do foco sejam estabelecidos tanto a partir do exame da literatura sobre o assunto, quanto pelo contato com o campo empírico' (BRAGA, 2001, p. 187).

O estudo feito em pesquisas sobre o componente Educação Física, mediante o levantamento de dissertações e teses com análises etnográficas e curriculares, revelou a existência de pesquisas sem registros de trabalho de campo (GRAMORELLI, 2007); com registros de aula de outra disciplina (CASELLI, 2012); sobre práticas religiosas (RIGONNI, 2008) e, especificamente, sobre as aulas escolares de Educação Física (ROCHA, 2014; UCHOGA, 2012; OLIVEIRA, 2010). Autoetnografias escolares, nas quais o pesquisador seria o próprio professor em seu cotidiano de aulas, não foram identificadas. Referências aos documentos curriculares oficiais foram feitas em relação à Proposta Curricular do Estado de São Paulo, identificadas em duas das pesquisas que abordaram as práticas pedagógicas, envolvendo professores e alunos nas aulas de Educação Física (ROCHA, 2014; UCHOGA, 2012).

Neira (2011c), em crítica já referida a este currículo oficial - como superficial, fragmentado e assimilacionista, - afirma que pelos seus conteúdos, do modo como são abordados no documento, é possível observar a intenção de formar sujeitos com competências e habilidades orientadas pelos sentidos e significados atribuídos pelos grupos dominantes. As reduções de espaços, para manifestações de concepções diferentes, reforçam a manutenção e o conformismo com a sociedade, tal qual a forma com que ela vem se apresentando. 
Currículos assim formatados se configuram como campos fechados, impermeáveis ao diálogo com o patrimônio cultural que caracteriza a diversidade que coabita a sociedade. Tais propostas, no nosso entender, se coadunam com um projeto pedagógico idealizado pela sociedade neoliberal, na qual, o mercado, a competitividade e a meritocracia são palavras de ordem (NEIRA c, 2011, p. 26).

Do conjunto ampliado de 13 pesquisas, nos sete trabalhos não analisados na íntegra, todos podem ser agrupados em uma única classificação, pois se referem diretamente ao tema das práticas pedagógicas de Educação Física em suas aulas, como em Chaim (2007), sobre o repertório cultural corporal dos jovens na elaboração de proposta curricular de intervenção sociocultural; Oliveira (2006), que trata da diferença nas aulas e a perspectiva curricular intercultural de Educação Física; Souza (2008), sobre as representações que os alunos possuem sobre o componente no Ensino Médio; Rodrigues Jr (2008), sobre os saberes cotidianos da cultura corporal dos alunos e as aulas de Educação Física; Ferreira (2015), que aborda a produção de significados das diferenças nas dinâmicas culturais infantis; Rigonni (2013), sobre a formação religiosa das alunas em relação às aulas no Ensino Médio e Celante (2014), que trata da constituição dos saberes docentes escolares pelos professores de Educação Física.

Das etnografias analisadas integralmente, dois conjuntos podem ser estabelecidos: um com temas sobre currículos oficiais, de caráter normativo governamental (PCN) (GRAMORELLI, 2007); outro institucional escolar, privado e internacional (PYP) (CASELLI, 2012); e um sobre os efeitos das práticas de culto e formação religiosa para as aulas de Educação Física (RIGONI, 2008). O segundo grupo é o que confere ênfases às observações participantes sobre aulas escolares em Educação Física, com temas sobre o currículo e a prática pedagógica (ROCHA, 2014); sobre relações de gênero e os conteúdos (UCHOGA, 2012); e sobre formas de (não) participação de alunos e alunas nas aulas de Educação Física (OLIVEIRA, 2010). Deste último grupo, Rocha, (2014) e Uchoga (2012) estabelecem relações diretas sobre as implicações curriculares do (PCSPEF) e as aulas realizadas.

Ao considerarem-se estes dois conjuntos, constata-se o modo acentuado de como o referencial teórico metodológico etnográfico é utilizado na coleta de dados, análises e interpretações de pesquisas sobre práticas pedagógicas escolares em Educação Física, em suas aulas, nos seus procedimentos didáticos, em correlações diretas ou indiretas com pressupostos teóricos e ou documentais curriculares. A presença de outros temas, que não 
ligados diretamente aos acontecimentos das aulas, mas que possuem implicações para o ensino do componente, reforçam as possibilidades instrumentais e analíticas que o referencial etnográfico disponibiliza para as pesquisas escolares em Educação Física.

Nesse caso, merecem destaque as questões relativas ao gênero frequentes no conjunto das pesquisas. As abordagens sobre como se dá a participação das meninas nas aulas, remetem-se a um aspecto histórico bastante problemático das práticas pedagógicas em Educação Física. Uchoga (2012) parece defender que a variedade nos conteúdos nas aulas tem importância significativa, no processo de participação de meninos e meninas, chamando a atenção, portanto, para a observância e centralidade do planejamento e procedimentos didáticos que dizem respeito às aulas mistas.

Cabe ressaltar que a utilização da Etnografia, como método de pesquisa, que subentende uma série de passos e pressupostos que devem permear o trabalho do investigador, desde a imersão no universo a ser pesquisado, tempo desta imersão, o estreitamento das relações estabelecidas em campo, a adequada articulação entre análises documentais, uso de entrevistas semiestruturadas e observação participante em relação ao referencial teórico-conceitual-metodológico determinado.

Assim sendo, alguns trabalhos analisados deixam a desejar ao considerarem-se esses pontos, como na pesquisa de Gramorelli (2007), por exemplo, na qual a coleta de dados de campo foi, exclusivamente, feita através de um encontro de grupo focal. Grupo esse reunido por meio de convite dirigido, mas que sem expressar exatamente quais finalidades e efetiva temática estaria a ser discutida e cuja programação incluía intensa sequência de atividades, como leituras, assistências de vídeos e debates sobre questões problematizadoras sobre conteúdos e avaliação. A questão que se nos apresenta, neste caso, refere-se ao curto espaço de tempo (duas horas) já preenchido com uma programação colocada a priori em que, admite a autora, os sujeitos não conseguiram relacionar as discussões com os PCN - o que era um dos objetivos do trabalho.

Não obstante a criteriosa análise dos documentos oficiais, em sua elaboração e conteúdos que fundamentaram as atividades do grupo focal e as análises dos dados obtidos, permanece a questão que, se em relação aos objetivos estabelecidos na pesquisa que incluía a apreciação dos PCN por professores, que tiveram acesso ao documento em sua formação acadêmica e profissional, o exercício de observações participante, não corroboraria melhor na estratégia metodológica, comparando, aproximando falas detectadas sobre o assunto, junto aos professores, de suas efetivas práticas pedagógicas, daquilo que de fato estaria acontecendo nas aulas. 
Dentre as técnicas de coleta de dados no referencial etnográfico, a observação participante é uma forma bastante utilizada e necessária. Uma das questões que se pode levantar é que esta forma deve estar associada a outras como, por exemplo, as entrevistas semiestruturadas. Estas entrevistas poderiam conter questões que corroborassem as observações feitas pelo pesquisador, para tentar minimizar o fato de que as suas observações serão sempre permeadas pela sua forma de ver o mundo, não que as suas observações precisem "ser verdadeiras" ou que as explicações destas, dadas através da entrevista pelos sujeitos "sejam as verdadeiras", trata-se simplesmente de formas variadas de coletar os mesmos dados, o que nos daria uma maior proximidade da realidade vivencial de um determinado grupo, de uma determinada prática.

Os currículos Crítico-superador e Cultural da Educação Física defendem de forma incisiva a consideração da cultura local, daí a importância da prática social inicial e do mapeamento. Logo nos parecem muito pertinentes os estudos que tentaram buscar aspectos culturais de determinados grupos e seus possíveis impactos nas aulas de Educação Física, como Rigoni, (2008) o faz, ainda que não tenha observado as aulas e tenha se limitado a participar dos cultos, atividades de formação e entrevistar diferentes participantes. Um exemplo claro da desconsideração da cultura dos alunos, nas aulas de Educação Física, aparece na fala de uma das entrevistadas que afirma ter uma professora menosprezado sua religião. Ora, se a religião, como atesta a pesquisadora, tem tanto peso nas práticas corporais e é também de práticas corporais que tratam as aulas de Educação Física, como desconsiderá-la, tratá-la com desdém e/ou mesmo minimizar a sua importância?

Nos limites encontrados do presente estudo, o fato de não ter sido possível relacionar pesquisas que se valessem diretamente de outros referenciais curriculares oficiais ou pelos princípios, procedimentos, pedagógicos e didáticos, dos Currículos Crítico-superador ou Cultural, sugerem a possiblidade de que devam ser realizadas buscas por pesquisas etnográficas ou autoetnográficas em Educação Física, com os devidos aprofundamentos sobre tais concepções, além de ajustes nos enfoques das triangulações feitas entre os referenciais teóricos curriculares críticos e pós-críticos; os documentos oficiais; as descrições, relatos e análises sobre práticas pedagógicas escolares em Educação Física.

O potencial identificado sobre o referencial teórico e metodológico etnográfico para as pesquisas em Educação Física não se refere exclusivamente ao trato de pesquisas com finalidades acadêmicas, científicas, na produção de dissertações e teses, mas também 
e especialmente como meios de se produzir conhecimentos sobre as aulas pelos próprios professores da disciplina. Neira (2011b), por exemplo, afirma o importante papel que a etnografia cumpre nos procedimentos didáticos do Currículo Cultural.

Concebido como ação didática do currículo cultural em educação física, a etnográfica significa aproximar-se das práticas corporais e colocar uma lente de aumento na dinâmica das relações e interações que constituem o seu funcionamento, para tentar entender como operam os mecanismos de dominação e de resistência, de opressão e contestação, além do papel e a atuação dos praticantes (p.117).

As inflexões, realizadas em relação à constituição dos bancos de dados e consequentemente da redução do número de teses e dissertações etnográficas em Educação Física, analisadas nesta pesquisa, permitem indicar que suas continuidades possam ser encaminhadas na consecução de levantamentos em outros programas de pósgraduação de Educação e Educação Física, estaduais ou federais, públicos ou privados.

Ampliando as possibilidades de análises, em relação ao material empírico, estariam sendo feitas em produções acadêmicas etnográficas sobre formação inicial e continuada, assim como e, especialmente, sobre os registros de práticas pedagógicas escolares em Educação Física, publicados nas formas de artigos ou relatos de experiência como, por exemplo, os que dizem respeito ao Currículo Cultural, com vasta produção acessível de relatos sobre aulas elaboradas pelos membros do Grupo de Pesquisas em Educação Física Escolar (GPEF) da FEUSP.

Assim sendo, seria de vital importância que pesquisas, que utilizam o referencial teórico/conceitual da etnografia e de currículos, pudessem ser mais utilizadas nas investigações em Educação Física Escolar, para que se possa ter uma visão cada vez mais extensa e específica do que se tem feito na prática.

O que de fato os professores e professoras de Educação Física têm levado a efeito, que estratégias têm utilizado, seus objetivos e conquistas, suas dificuldades perante os currículos oficiais e a realidade da sala de aula? Pensando nisso, recordamos uma fala de uma professora durante um evento de formação em Curitiba, onde ela dizia: "sabemos perfeitamente que devemos evitar a simples esportivização das aulas, mas daí chega um camarada muito mais forte e alto do que você e diz: "Hoje é futebol, não é professora?"

Questões como estas precisam ser respondidas. Questões como estas precisam ser levantadas e precisamos cada vez mais produzir conhecimento nesta área, registrando as 
vozes e descrevendo as ações dos vários grupos sociais que compõem a comunidade escolar; dos professores (as) e alunos (as) que, em última análise, são os que estão diretamente no campo. É preciso ir a este encontro para que possamos perceber a amplitude destes trabalhos e para de fato buscar contribuir em seus avanços. 


\section{REFERÊNCIAS}

BRACHT, V. A prática pedagógica em educação física: a mudança a partir da pesquisaação. Revista Brasileira de Ciências do Esporte, Campinas. Campinas, v. 23, n. 2, p. 9-29, jan. 2002.

BRACHT, V.; CAPARROZ, F.C. O Tempo e o lugar de uma didática da Educação Física. Revista Brasileira de Ciência do Esporte, Campinas, v. 28, n. 2, p. 21-37, jan. 2007.

BRACHT, Valter et al. A Educação Física Escolar como tema da produção do conhecimento nos periódicos da área no Brasil (1980-2010): parte II. Movimento, v. 18, n. 2, p. 11-37, 2012.

BRAGA, T. M. F. G. Origens e questões da etnografia educacional no Brasil: um balanço de teses e dissertações (1981-1998). 2001. 308 f. Tese (Doutorado em Educação).Faculdade de Educação. Universidade de São Paulo, 2001.

BUENO, B. O. Entre a Antropologia e a História: uma perspectiva para a e etnografia educacional. Perspectiva, Florianópolis, v. 25, n. 2, 471-501, jul./dez. 2007.

CALDEIRA, T.P.R. A Presença do Autor e a Pós-Modernidade em Antropologia. Novos Estudos CEBRAP, São Paulo, n. 21, p. 133-157, 1988.

CASELli, A. J. A Educação Física articulada ao currículo transdisciplinar. 2012. 160 f. Dissertação (Mestrado em Educação) Escola de Educação Física e Esporte, Universidade de São Paulo, 2012

CELANTE, A. R. Educação física escolar e os saberes na ação docente. 2014. 195 f. Tese (Doutorado em Educação Física). Faculdade de Educação Física. Universidade Estadual de Campinas, Campinas, 2014.

CHAIM JUNIOR, C. I. Cultura corporal juvenil da periferia paulistana: subsídios para construção de um currículo de educação física.2007. 130 f. Dissertação (Mestrado em Educação) Escola de Educação Física e Esporte, Universidade de São Paulo, 2007.

COlETIVO DE AUTORES. Metodologia do Ensino de Educação Física. São Paulo: Cortez, 1992.

DEMARTINI, Z. de B. F. Infância, Pesquisa e Relatos Orais. In: FARIA, A G.de; DEMARTINI, Z. de B. F.; PRADO, P. D. (Orgs.). Por uma cultura da infância: metodologias de pesquisa com crianças. 3ed. Campinas: Autores Associados, 2009.

DAOLIO, J. A Antropologia social e a Educação Física: Possibilidades de encontro, in: CARVALHO, Y. M. e RUBIO, Educação Física e Ciências Humanas. São Paulo: HUCITEC, 2001.

EZPELETA J. \& ROCKWELL, E. A Escola: relato de um processo inacabado de construção. Currículo sem Fronteiras, México, v.7, n.2, p.131-147, Jul/Dez, 2007. 
FERREIRA, F. M. Diferenças, inclusão e educação física: significados produzidos pelas crianças.2015. 129 f. Dissertação (Mestrado em Educação Física). Faculdade de Educação Física. Universidade Estadual de Campinas, Campinas 2015.

FONSECA, C. Quando cada caso NÃO é um caso: Pesquisa etnográfica em educação. Revista Brasileira de Educação, São Paulo, v. 10, p. 58-78, jan./abr, 1999.

GASPARIN, J. L. Uma Didática Para Pedagogia Histórico Crítica. Campinas: Autores Associados, 2007.

GEERTZ, C. A interpretação das culturas. São Paulo: LTC. 1989.

GRAMORELLI, L. C. O impacto dos PCN na prática dos professores de educação física. 2007. 153 f. Dissertação (Mestrado em Educação) Escola de Educação Física e Esporte, Universidade de São Paulo, 2007.

KUNZ, E. Transformação didático-pedagógica do esporte. 6. ed. Ijuí: Unijuí, 2004.

KUNZ, E. Educação Física: Ensino e mudanças. Ijuí: Unijuí, 1991.

LEMINSKY, Paulo. Toda poesia. $1^{\circ}$ ed. São Paulo: Companhia das letras, 2013.

MAGNANI, J. G. C. Antropologia e educação física. In: CARVALHO, Y M; RUBIO, K (orgs.). Educação Física e Ciências Humanas. São Paulo: Hucitec, p.17-26 ,2002.

MARTINS, N. R.; SILVA, R. V. S. Pesquisas brasileiras em Educação Física e Esportes: tendências das teses e dissertações. Disponível em: <http:// www.nuteses.ufu.br/trabalho_2.pdf>. Acesso em: 20 jan. 2016.

MOLINA NETO, V. Etnografia: uma opção metodológica para alguns problemas de investigação no âmbito da Educação Física. In: MOLINA NETO, V; TRIVIÑOS, A.N.S. (Orgs.). A Pesquisa Qualitativa na Educação Física. 1 ed. Porto Alegre-RS, v. 1, p. 107-140, 1999.

MOLINA NETO, V. Dicionário Crítico de Educação Física (Etnografia e Formação Permanente). Ijuí: Unijuí, 2005.

NEIRA, M.G. O currículo cultural da Educação Física em ação: a perspectiva de seus autores. Tese (Livre-Docência) Faculdade de Educação. Universidade de São Paulo. São Paulo: FEUSP, 2011a.

. Educação Física. São Paulo: Blucher, 2011b (Coleção: A reflexão e a prática do ensino; v.8).

. A proposta curricular do Estado de São Paulo na perspectiva dos saberes docentes. Revista brasileira de educação física e esporte, São Paulo, n.25, 23-27, $2011 \mathrm{c}$. 
NEIRA, M G. Análises dos currículos estaduais de Educação Física: inconsistências e incoerências percebidas. Cadernoscenpec, São Paulo, v.5, n.2, p.233-254, jul-dez 2015.

NEIRA, M. G.; NUNES, M. L.F. Educação Física Currículo e Cultura. São Paulo: Phorte, 2009.

NEIRA, M. G. Educação Física escolar: por uma pedagogia cultural. In: NEIRA, M. G.; UVINHA, R. R. Cultura Corporal: diálogos entre educação física e lazer. Petrópolis: Vozes, 2009.

OLIVEIRA, R. C. de. Educação física, escola e cultura: o enredo das diferenças. 2006. 102 f. Dissertação. (Mestrado em Educação Física)-Faculdade de Educação Física. Universidade Estadual de Campinas, Campinas, 2006.

. Na "periferia" da quadra - Educação Física, cultura e sociabilidade na escola. 2010.Tese (Doutorado em Educação Física). Faculdade de Educação Física. Universidade Estadual de Campinas, Campinas 2010.

PEIRANO, M. G. S. A favor da etnografia. Rio de Janeiro: Relume-Dumará. 1992.

REIS, A. de P. et al. Pedagogia Histórico-crítica e Educação Física. Juiz de Fora: Editora UFJF. 2013

RIGONI, A. C. Marcas da religião evangélica na educação do corpo feminino: Implicações para a Educação Física Escolar.2008. 162 f. Dissertação (Mestrado em Educação Física) Faculdade de Educação Física. Universidade Estadual de Campinas, Campinas, 2008.

. Corpos na escola:(des) compassos entre a educação física e a religião.

2013. 176 f. Tese (Doutorado em Educação Física). Faculdade de Educação Física, Universidade Estadual de Campinas, Campinas, 2013.

ROCHA, R. L. F. da A prática pedagógica de educação física a partir do currículo de São Paulo. 209 f. Dissertação (Mestrado), Faculdade de Educação Física, Universidade Estadual de Campinas, Campinas 2014.

ROCKWELL, E. La experiência etnográfica: Historia y cultura em los processos educativos. Buenos Aires: Paidós. 2009.

ROCKWELL, E. Reflexiones sobre el proceso etnografico (1982-1985). Departamento de Investigaciones Educativas, Centro de Investigación y de Estudios Avanzados, Mexico, 1987

ROCKWELL, E. Del campo al texto: dilemas del trabajo etnográfico, in JOCILES, M.J.; FRANZÉ, A. (eds.), ¿Es la escuela el problema? Perspectivas socio-antropológicas de etnografía y educación, Madrid, Trotta, p. 90-103, 2008.

RODRIGUES JUNIOR, J.C. Os saberes cotidianos de alunos nas aulas de Educação Física: implicações para a prática pedagógica.2008. 159 f. Dissertação (Mestrado), Faculdade de Educação Física, Universidade Estadual de Campinas, Campinas 2008. 
SAVIANI. D. Escola e Democracia. 35.ed. São Paulo: Autores Associados, 2006

SOUZA, A. S. Educação física no ensino médio: representações dos alunos. 2008. 148 f. Tese (Doutorado em Educação Física) Faculdade de Educação Física, Universidade Estadual de Campinas, Campinas, 2008.

STOER, S.R.; CORTESÃO, L. Levantando a pedra: Da pedagogia inter/multicultural às políticas educativas numa época de transnacionalização. Porto: Afrontamento, 1999.

UCHOGA L. A. R. Educação Física Escolar e Relações de Gênero: Risco, confiança, organização e sociabilidades em diferentes conteúdos.2012. 191 f. Dissertação (Mestrado em Educação Física) Faculdade de Educação Física. Universidade Estadual de Campinas, Campinas, 2012. 
APÊNDICE A - ETNOGRAFIAS EM EDUCAÇÃO FÍSICA. ${ }^{35}$

\begin{tabular}{|c|c|c|}
\hline $\begin{array}{l}\text { Autores; programas de pós-graduação; orientadores; } \\
\text { agencias financiadoras; ano de conclusão; tipo de } \\
\text { unidade estudada, de acordo com dependência } \\
\text { administrativa; trabalhos por número de unidades de } \\
\text { estudo; sobre a identificação da metodologia de } \\
\text { pesquisa; quanto ao tempo de desenvolvimento da } \\
\text { pesquisa de campo; sobre as técnicas usadas no } \\
\text { trabalho de campo; sobre a identificação e as } \\
\text { técnicas de coleta de dados. Relação entre } \\
\text { denominação, tempo e técnicas. }\end{array}$ & $\begin{array}{l}\text { PONTOS DE } \\
\text { PARTIDA } \\
\text { Metodologia }\end{array}$ & $\begin{array}{l}\text { TEMPO } \\
\text { Está descrito em termos de tempo? } \\
\text { OBSERVAÇÃo } \\
\text { Inclui observação? De que tipo? } \\
\text { ENTREVISTA } \\
\text { Inclui entrevistas? De que tipo, com } \\
\text { que finalidade? } \\
\text { Abertas - Estruturadas } \\
\text { Semiestruturadas. } \\
\text { ANÁLISE DOCUMENTAL } \\
\text { Inclui análise documental? Com que } \\
\text { finalidade? } \\
\text { Inclui outras formas de coleta de } \\
\text { dados? Quais e com que finalidade? } \\
\text { REGISTROS DE CAMPO } \\
\text { De que tipos são? } \\
\text { Aparecem registros completos em } \\
\text { anexo? Em partes? Como exemplos? } \\
\text { Que características eles têm? } \\
\text { DURAÇÃo }\end{array}$ \\
\hline Identificação & $\begin{array}{l}\text { Dissertações } \\
\text { Teses } \\
\text { EF Escolar }\end{array}$ & $\begin{array}{c}\text { Campo: } \\
\text { tempo/técnicas/registros }\end{array}$ \\
\hline $\begin{array}{l}\text { Está escrito em 1a pessoa? Em 3ạ? } \\
\text { O estilo é descritivo? É uma descrição densa? } \\
\text { Apresenta, reproduzindo, "falas" dos sujeitos? } \\
\text { Apresenta teorias articuladas às descrições? } \\
\text { Apresenta interpretações do pesquisador? } \\
\text { Revela as etapas do trabalho de campo? } \\
\text { Revela decisões tomadas pelo pesquisador? }\end{array}$ & $\begin{array}{c}\text { Texto } \\
\text { Características } \\
\text { e } \\
\text { Análises. }\end{array}$ & $\begin{array}{l}\text { São predominantemente descritivas? } \\
\text { Remetem a conceitos/teorias? De que } \\
\text { tipo? } \\
\text { De que campo do conhecimento? } \\
\text { É definida centralmente em termos da } \\
\text { compreensão dos significados } \\
\text { atribuídos pelos sujeitos a sua própria } \\
\text { realidade social? } \\
\text { O material de campo é usado para a } \\
\text { construção de novas relações (que dão } \\
\text { conta do local, particular e complexo) } \\
\text { sobre o objeto de estudo? } \\
\text { Está referida como processo que } \\
\text { ocorre em etapas determinadas da } \\
\text { investigação? Durante o trabalho de } \\
\text { campo? Ao final? }\end{array}$ \\
\hline
\end{tabular}

${ }^{35}$ FONTE: BRAGA, Tânia M. F. G. Origens e questões da etnografia educacional no Brasil: um balanço de teses e dissertações (1981-1998). FEUSP, Tese (Doutorado em Educação) 308 p. 2001. 


\section{APÊNDICE B - CURRÍCULO CRÍTICO - SUPERADOR ${ }^{36}$}

\begin{tabular}{|c|c|c|}
\hline Prática social inicial & Classes Sociais & Instrumentalização \\
\hline Problematização & $\begin{array}{c}\text { Transformação } \\
\text { Social }\end{array}$ & Catarse \\
\hline Ideologia & Práxis & Prática social final \\
\hline
\end{tabular}

\section{APÊNDICE C - CURRÍCULO CULTURAL ${ }^{37}$}

\begin{tabular}{|c|c|c|}
\hline $\begin{array}{c}\text { Cultura corporal da } \\
\text { comunidade }\end{array}$ & $\begin{array}{c}\text { Tematização } \\
\text { Problematização }\end{array}$ & $\begin{array}{c}\text { Articulação com os objetivos } \\
\text { educacionais } \\
\text { da instituição educativa }\end{array}$ \\
\hline Mapeamento & Justiça Curricular & Genealogia Arqueológica \\
\hline $\begin{array}{c}\text { Ancoragem social dos } \\
\text { conhecimentos }\end{array}$ & Registro e avaliação & $\begin{array}{c}\text { Aprofundamento, ampliação e } \\
\text { ressignificação }\end{array}$ \\
\hline
\end{tabular}

${ }^{36}$ Fonte: REIS, A. P. et al. Pedagogia Histórico- Crítica e Educação Física. 2013. Editora UFJF.

${ }^{37}$ FONTE: NEIRA, M.G. O currículo cultural da Educação Física em ação: a perspectiva de seus autores. Tese (Livre-Docência) Faculdade de Educação. Universidade de São Paulo. São Paulo: FEUSP, 2011. 